University of Rhode Island

DigitalCommons@URI

Open Access Master's Theses

1978

\title{
A Residential Growth Control Plan for North Kingstown (1978-1993)
}

Marc A. Levye

University of Rhode Island

Marc R. Rousseau

University of Rhode Island

Follow this and additional works at: https://digitalcommons.uri.edu/theses

\section{Recommended Citation}

Levye, Marc A. and Rousseau, Marc R., "A Residential Growth Control Plan for North Kingstown (1978-1993)" (1978). Open Access Master's Theses. Paper 613.

https://digitalcommons.uri.edu/theses/613

This Thesis is brought to you for free and open access by DigitalCommons@URI. It has been accepted for inclusion in Open Access Master's Theses by an authorized administrator of DigitalCommons@URI. For more information, please contact digitalcommons-group@uri.edu. 
A RESIDENTIAL GEOWTH CONTROL HLAN

FOR NORTH KINGSTOWN, (1978-1993)

EY

MARC A. LEVYE

ANi D

NARC R. ROUSSEAU

\begin{abstract}
A NASTER'S RESEARCH FEOJECI
SUBMITTED IN PARTIAL FULFILLYUN OF THE RLQUIEENEN'L'S FOR THE DEGREE OF'

MASTER OF COMMUNITY FLANNING
\end{abstract}

UNIVERSITY OF RHODE ISLAND

NAY, 1978 
MASTER OF COMMUNITY PLANNING

RESEARCH PROJECI

$O F$

MARC A. LEVYE

AND

MARC R. ROUSSEAU

APPROVED:

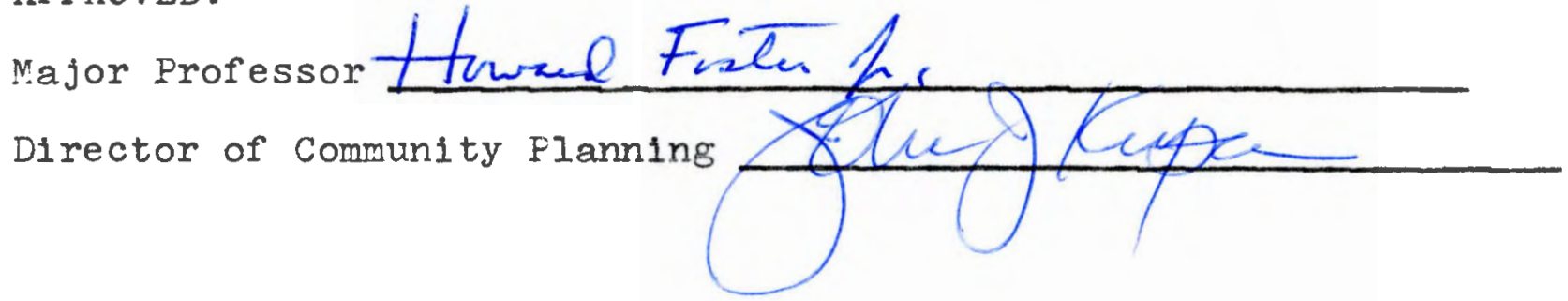

UNIVERSITY OF RHODE ISLAND

MAY, 1978 


\section{Acknowledgements}

We w1sh to take this opportunity to express our appreciation to $\mathrm{Dr}$. Howard H. Foster for his time and assistance in making this project possible. In addition, special thanks goes to Dr. John Kupa, Director of the Graduate Curriculum in Community Planning and Area Development, and Mrs. Marion R. Paradis, Financial Director of North Kingstown. In serving as our secondary advisors, their highly regarded expertise was most welcome. Our thanks extends also to Mr. John A. Mulligan, Town Manager of North Kingstown and the various departments of town government for their invaluable ald in the collection of data. 


\section{Preface}

Our growth control scheme is a starting point in the development of a "comprehensive" framework for the discussion of land use policy and growth in the Town of North Kingstown. Rhode Island. The plan is dynamic, one flexible to accommodate the people's needs.

The study area was Iimited to residential development in the town. It could have been expanded to include industrial and commercial uses but a different focus and additional research would have been necessary.

It is important to state that we have decided to leave Quonset/Davisville out of our study. The reasons are many. To begin with, time was a factor. In addition, various levels of government are involved with this large tract of land as well as numerous interest groups, such as the oil research and development support industries. Future re-use of the area is unpredictable. The impact of its re-use would be of great benefit to the town in terms of tax revenues and mixed land and recreational uses. Some potential costs may be involved. Nevertheless, Quonset/Davisville is of local, state, regional, national, and intermational significance, and, therefore, is beyond the scope of this particular project. The project consists of five chapters. They are as follows: 
Chapter 1. Introduction - This chapter will focus in on the land use problem in the United States and suggests the "timing" of development as a technique for managing growth. Issues and problems faced at the local level by those wishing to manage growth will also be highlighted.

Chapter 2, Justification for a Growth Control Strategy in North Kingstown - This chapter will make a strong case for a more "comprehensive" permit scheme which equates land use development with sound financial planning.

Chapter 3 Growth Control Methodology - This chapter, the most lengthy, presents a general discussion of our particular growth control program. its specific components including our proposed Capital Improvement Program, and a general discussion concerning the issue of "remedies" and "just compensation."

Chapter 4, Application of Methodology - Th1s chapter simply illustrates how our methodology works, We accomplish this through two hypothetical examples.

Chapter 5 , Conclusions - Th1s chapter w1ll offer a brief summary of our proposal. In addition. suggestions will be made on how the Town could begin to put our plan into effect. It will also make clear the point that rapid development w1ll occur in North Kingstown regardless of the redevelopment of Quonset/Davisvilie. Understandably, its re-use would make a growth control plan all the more necessary. Finally, a short look past the effects of our plan (1993) w1ll be included.

In addition, the report contains four appendices, two of which present rather extensive and important information. Appendix A - This appendix presents our Model Growth Control Amendment to Zoning ordinance, North Kingstown.

Appendix B - This appendix contains vital legal considerations.

The overall goal of our project is to develop a growth control plan tallored specifically to the Town of North 
K1ngstown, Rhode Island.

The objectives of our study are to:

1) establish a system which ensures a reasonable growth rate in relation to the provision of capital facilities and services;

2) provide for more energy-efficlent development; and.

3) to make provision for necessary low and moderate income housing in the community.

The basic methodology of our growth control plan consists of a point system for residential development. Points are awarded upon the avallability of public facilities, consideration of energy elements, and the provision of low and moderate income housing. We propose that the growth control plan be incorporated into the town's zoning ordinance.

As in Ramapo, New York, the Capital Improvement Program w1ll be sequenced with development. In other words, the ability of a developer to secure the standard number of points w1ll be contingent, in part, on the Town's or developer's ablilty to provide public facilities. We have proposed three, five-year capital improvement plans.

The legality of our scheme is dependent on proposed state enabling legislation. One looks optimistically towards the future.

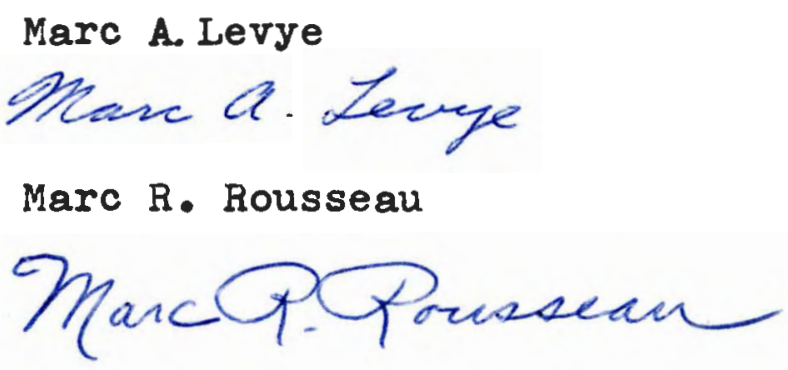




\section{TABLE OF CONTENTS}

CHAFTER ONE

Land Use and Development Issues in

the United States .......... . . .

Page

CHAPTER TNO

Justification for Utilizing a Growth Control

Strategy in North Kingstown . . . . . . .

CHAPTER THREE

Growth Control Methodology . . . . . . . 34

CHAPTER FOUR

Application of Methodology . . . . . . 69

CHAPTER FIVE

Conclusions . . . . . . . . . . . 87

APPEN DICES

Appendix A - Model Growth Control Amendment

to Zoning Ordinance, North Kingstown . . . 93

Append1x B - Legal Considerations . . . . . 105

Appendix C - Capital Improvement Program

Data ................... 123

AppendiX D - Low and Moderate Income Housing

Data ..................... 126

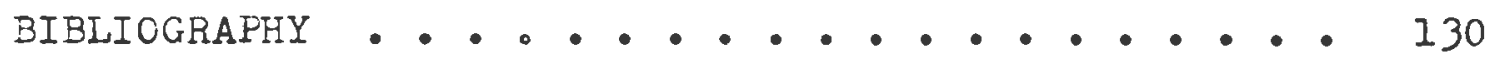

LIST OF CASES CITED . . . . . . . . . . . 134

LIST OF LAWS, CODES, ORDINANCES, AND GUIDELINES

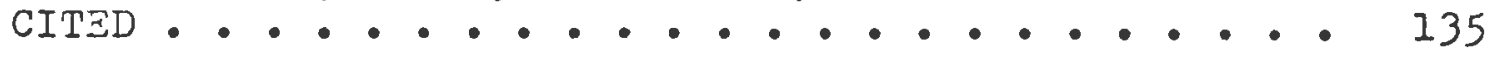

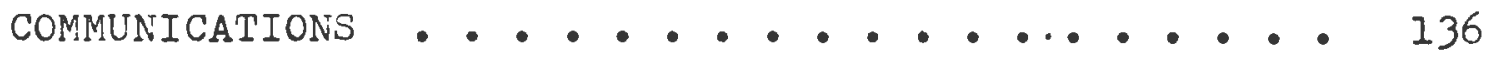


LIST OF FIGURES

Page

Figure I Public Facilities criteria . . . $38 \mathrm{~A}$

Figure II Incorporation of Site Objectives.. 51

Figure III Intra-Block Easement . . . . . 53

Figure IV Easement through Cul-de-sacs . . . 53

Figure V Street with Parking Bays ..... 55

Figure VI Energy criteria ........ $56 \mathrm{~A}$

Figure VII Iow and Moderate Income

Housing criteria ....... $61 \mathrm{~A}$

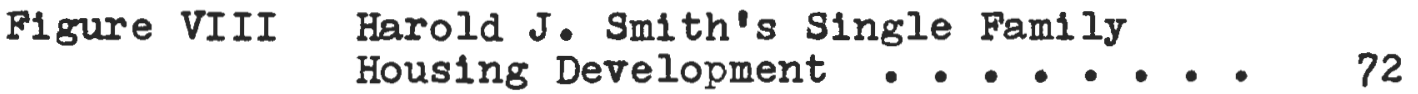

Figure IX Hoskins Estates, Cluster

Development ....... 80 
MAPS

Page

North Kingstown, Regional Location . . . . . . . . . 22

North Kingstown, Base Map . . . . . . . . . . . 23

North Kingstown, Existing and Proposed Services . . . 70 


\section{LIST OF TABLES}

Table 1 R.I. Population Projections from $1975-1990$ Page for Selected Cities and Towns... . . . . 26

Table II New Housing Units Authorized by Building Permits in North Kingstown, 1973-1977.... . 27

Table III New Housing Units Authorized by Building Fermits for selected Cities and Towns in R.I.. 1976-1977 ............. 27

Table IV Survey of Land Use, North Kingstown . . . . . 50

Table $V$ Low and Noderate Income Housing Unit Limits for the Three Five Year reriods, 1979-1983, 1984-1988, and 1989-1993 ......... 60 
CHAPTER ONE

LAND USE AND DEVELOPNENT ISSUES IN THE UNITED STATES

A. The Land Use Problem in the United States

Since post World War II. America has experienced a profound rate of expansion. in terms of population and technology. The automobile, along with other modes of transportation, has given man the opportunity to travel freely and seek new areas in which to live. This has resulted in a pattern of highly scattered subdivisions across the landscape. Growth was seen by many as good and with seemingly unlimited natural resources. This prevaling attitude, concerning land as an unlimited resource, was brought to America by early European immigrants. As Hans Blumenthal states:

America became the fulfillment of Europe's dream. It was the 'land of the free' because the land was free. It was free to take and to sell and buy. It was free to be subjected, appropriated by whoever had the power to buy. Iand was no longer sacred. it was a commodity, 'real estate'.1

The future appeared to be full of promise and optimism. However, In recent years, the affects of growth are now being painfully realized. Pollution of our environment is one ugly by-product of such growth. Books such as Future Shock ${ }^{2}$ and The Closing Circle. 3 have emphasized the need for effective control and rational allocation of all natural resources. The National Environmental Policy Act of $1970^{4}$ was a direct response to the detrimental consequences of man's interrelation- 
ship with his surrounding environment.

Hans Blumenthal states:

In western thought, there is no counterpart to the anclent wisdom of Feng-Shul-wind water-wh1ch has governed Chinese city planning. ... The anclent gods of the soll w1ll not tolerate the violation of their laws. Man may forget that he $1 \mathrm{~s}$ part of nature and treat her merely as a source of "raw materials" to be utilized and then be thrown away as "waste." but the waste returns to haunt him. He can continue to live only if he preserves and restores the ecological balance. 5

Today, the Western ethic of unlimited growth is increasingly challenged. No longer is 1 t being accepted as a premise of progress. Its effects on the quality of life are widely debated, and 1 ts management and control are seen by many as essential elements of modern land use policy.

Robert Cahn is one author who feels that concern for the "quality of life" is replacing America's "growth mystique." He writes:

Many citizens are conscious that new development carries potential economic hardships as well as harmful environmental effects. The ready assumption of city or county officials that new growth automatically brings more jobs and more tax benefits has been sharply questioned in studies and in the personal experience of many taxpayers who find that the services required to accommodate the new growth can be more costly than the tax benefits derived therefrom.... Some growth is tnevitable but we need adequate planning for $1 t^{6}$

It is a fact that industry and people w1th the sufficient resources are leaving the large urban cities and moving to suburban/rural locations. What has resulted is a substantial reduction of revenues, to the municipality, usually in the form of taxes. The municipality's physical qualities tend to deteriorate as it becomes increasingly difficult to 
provide the necessary services and facilities. It is the outlying areas which recelve this influx of growth. Such "leapfrogging" development creates two problems for suburban towns: 1) It is very costly to serve such subdivisions with adequate public facilities and services; and 2) it tends to create permanently misplaced pieces of a j1g-saw puzzle which would never fit into an orderly pattern envisioned by a master plan.? What results from such a situation are skyrocketing tax rates and the threat of inadequate services endangering the health, safety, morals, and the general welfare of the community. ${ }^{8}$ B. Timing/Phasing: A Technique for Managing Growth

There have been various efforts to control and regulate the timing and location of private residential development in accordance with the municipalities' ability to provide the necessary community facilities and services and to gulde orderly development. The 1dea behind these schemes was introduced by Henry Fagin in 1955. In his article. "Regulating the Timing of Urban Development," 9 Fagin states that planning involves space and time. "Effective urban planning demands a simultaneous attention to both." He says that time coordination consists of regulating the tempo (rate of development) and sequence (the where/when). The author presents the reader with five valid planning bases for timing control. The are:

to 1) secure economy in the provision of municipal services and facilities; 2) maintain these services and facilities at a high level; 3) control the character of development; 4) maintain a desirable balance of land uses; and 5) thus protect the public interest. 10 
Stephen L. Urbanczyk, in "Phased Zoning: Tempo/ Sequence of Development" reiterates the position of Henry Fagin in stating the need for "direct. flexible tempo and sequence controls that enable (municipalities) to balance over time increasing housings needs with diminished land resources and increased needs for public services with tight municipal budgets."1l

Hyung $C$. Chung $^{12}$ points out. in "Regulating the Timing of Residential Development-The Ramapo Study." that the Milford (Connecticut) Planning Commission, in 1954, refused to approve a subdivision on the sole ground that "the town's financial nature made it unfeasible to provide sufficient schools and fire and police protection services for the population of the proposed development." The town lost in court on statutory grounds. (See Beach v. Planning and Zoning Commission of the Town of M11ford. 103 Atlantic 2 d. 815.)

As a result, Mr. Chung states:

The town developed new ordinance provisions which adopted a so-called 'subdivision priority map' as part of the official master plan. In this map. areas of the town already served adequately with facilities were designated as 'high priority areas' and those areas which are not as 'low priority areas.' The subdivision in the latter areas are allowed to be developed slowly taking several years in order to allow time for necessary municipal facilities to be constructed at a rate somewhat parallel with the rate of construction in the subdivision.' The regulations allow the private developers to speed up the development by eradicating the inadequacies of fac1lities with his own expenses. In such cases, the subdivision area is reclassified from a 'low' to 'high' priority area which has no ilmitation on the development rate.13

The town of Clarkstown. Rockland County. New York. 
In 1960, adopted a zoning ordinance which delineated three zones:

\begin{abstract}
a 15,000 to 22,500 square feet zone immediately surrounding the village center, a permanent acreage zone in the outermost parts of the town, and an 'Intermediate zone' which requires special permits if one wishes to subdivide parcels into less than 40,000 square feet lots.

The Town further stipulated that the granting of spectal permits is based upon the findings of the Town Board that 'existing facilities or plans or reasonable possibilities for the expansion of such facilities are adequate to provide for the needs of future residents in the proposed development' and that the health, safety, welfare, and morals of the Town will not be adversely affected.' The ordinance is designed directly to control the flexibility in residential density in the Intermediate Zone in commensurate with the ability of providing adequate public facilities and services, but no doubt it directly regulated the rate of development in that zone. 14
\end{abstract}

In Matter of Josephs v. Town of Clarkstown, 15 "the court affirmed a local community's power to regulate density of population zoning... and the court then proceeded to hold explicitly that a community may regulate its growth by taking into consideration the expected impact on public school facilities."

Norman Williams states, "this is a clear cut decision upholding a carefully thought out scheme to regulate development, taking into consideration, inter alla, the avallability of community facilities."16

In the Town of Ramapo, Rockland County, New York, a system was set up between 1965 and 1969, to organize, in a better fashion, the pattern of urban sprawl which had occurred. This sprawl created a fantastic rise in school taxes and a lack of low-income housing. As a result, the town adopted 
these goals:

1) the cost of municipal services and facilities were to be paired by carefully timing residential development according to efficient provision of public improvements; 2) the town was to maintain control over the eventual character of development: 3) the quality of community services and facilities was to be maintained; and 4) various uses of land were to be balanced.1?

The following describes the operation of the system in Ramapo, New York:

Since 1969. preliminary to approval of (building) permits for residential development in unincorporated areas, applications are submitted to the Administrative Assistant to the Board and Commissions for review and recommendations. The Town Board renders the decision.

All residential subdivisions of two or more lots are subject to special permit approval of the Town Board. An 18-year capital improvement plan (in three sixyear periods) schedules all sewage, drainage, recreation and park facilities, and improved roads through staging and sequencing in town areas. Development points are required based on the readiness of the site for development. Readiness is determined by capital improvement categories and fire stations.

The developer receives a special permit vesting a present right to develop at such time as the site has sufficient points for development. Developers may advance the date of development by installing and fumishing improvements to earn the site required points. Developers are encouraged to retain open space by dedicating development easements and obtaining reduced assessed valuation. All land restricted by ordinance is entitled to assessed valuation reductions to accord to restricted market value. Varlances are avallable for public low-income housing and other special public uses that conform to the comprehensive plan.18

The Town of Ramapo had developed a comprehensive plan for its future growth and upon this had based the eighteenyear capital improvement program setting out the town's schedule for construction of municipal services. Under the 
system. the town's provision of services needed for residential development would not be forthcoming for some propoerty for as long as elghteen years.

In upholding the Ramapo ordinance, the court polnted out that the restrictions on development were of limited duration and concluded:

In sum, where it is clear that the existing physical and financlal resources of the community are inadequate to furnish the essential services and facilities which a substantial increase in population requires, there is a rational basis for 'phased growth' and hence. the challenged ordinance is not violative of the Federal and State Constitutions.19

The court held that the ordinance was not excluslonary, but rather sought "to provide a balanced cohesive community dedicated to the efficient utilization of land."20 It noted that coupled with the town's restrictions were provisions for low and moderate income housing on a large scale.

The City of Petaluma, California, located just 40 miles north of San Francisco, in Sonoma County, experienced a population increase from 14.035 to 24,870 (77\%) between 1960 and 1970 . The clty was increasingly becoming a commuter suburb of San Franc1sco. Th1s rap1d growth caused concern among the c1tizenry who wanted to preserve their way of life, prevent environmental damage, and control the cost and quality of public services. In addition, the city lacked a mix of housing types.

Petaluma adopted a series of goals to meet these concerns.

Growth was to be limited to approximately 500 new housing units annually from 1973 to 1977. The c1ty's small town character and surrounding open space were to be preserved by controlling the rate and distribution of growth. Development was tied to school and 
ut1lity capacity and balanced between eastern and western sections. With the cooperation of Sonoma County, all urban and suburban development near the c1ty would be approved by and acceptable for annexation to the c1ty. A permanent green belt of open h1lls and marsh land and open space for recreation would be provided. Environment design plans, planned community districts, and planned unit developments would be required to gain the best design possible. Mult1-family units would be encouraged and a variety of densities and bullding types ensured. The central business district was to be rehabliltated as the principal commercial center of southern Sonoma County. 21

In early 1971, the City Counc1l adopted a moratorium

resolution. Citizens of Petaluma adopted a control ordinance In a special election in June 1972, and the Residential

Development Control system was revised and adopted by c1ty ordinance August 21, 1972.

System Operation in Petaluma. California

The Residential Development Control System applies to all developments of five or more units. The system is operated by the Residential Evaluation Board. a 17-member body composed of c1ty and school officials and private citizens. By september 1 each year, the C1ty Counc1l, by resolution, establishes allocation quotas for various types of dwelling units for each section of the c1ty. The total quota each year of the five-year program must be within 10 percent of 500 units. w1th future adjustments made so that the five-year total of permits issued 1s 2.500. At least 10 percent of the permits each year must be for low and moderate-income housing.

Applications for building permits for the ensuing year must be submitted to the Residential Development Control Board by September 1. The board must aff $1 \mathrm{rm}$ that the application conforms to the General Plan and the Environmental Design Plan. Which guides the c1ty's development. If the project conforms, it is then judged on the basis of 1 ts relation to or impact upon local public facilities, receiving from 0 to 30 points according to a rating system. The project is then given a rating from 0 to 80 depending on quality of design and contribution to public welfare and amenity. Extra points accrue for housing meeting 235 and 236 standards. The Board presents evaluations in terms of ratings to the City Council for development allotments. The council awards development 
allotments by resolution, starting with projects recelving the most points. Its actions are limited by program quotas, and it may eliminate from consideration any project with less than 25 points in the first category or 50 points in the second category. Developers may appeal to both the Board and the City Counc1l. The city and developers must act w1thin speoified time periods. 22

In 1974, a federal district court in California ruled the growth control ordinances of Petaluma unconstitutional on the grounds that they interfered with people's constitutional right to travel and live where they wish. ${ }^{23}$ The district court ruled that the plan amounted to an effort to avold the problems that accompany contemporary trends in population growth by limiting the number of people permitted to move into the clty. No compelling state interest was found to justify the abridgement of this right. The court broadly concluded:

A zoning regulation which has as 1 ts purpose the exclusion of additional residents in any degree is not a compeling governmental interest, nor is it one
within the public welfare.

The United States Court of Appeals for the Ninth Circuit reversed the decision of the district court. ${ }^{25}$ The court summarized 1 ts judgement as follows:

We conclude therefore that under Belle Terre and Los Altos Hills, the concept of the publio welfare is sufficiently broad to uphold Petaluma's desire to preserve 1ts small town character, 1ts open spaces and low density of population, and to grow at an orderly and deliberate pace. 26

In addition, the court sald the plan "offers new opportunities, previously unavallable, to minorities and low and moderate-income persons." 27 
The Construction Industry Association of Sonoma County petitioned the U.S. Supreme Court to review the circuit court's decision in the Petaluma case, but in February 1976. the U.S. Supreme Court denied this petition. As a consequence, the adoption of plans similar to Petaluma were expected to take place in other communities.

One such community is the City of Boulder, Colorado. Boulder is just 30 miles northwest of Denver. The climate is semi-arid. It is conceivable that Boulder may need to divert mountain waters from present agricultural usage if natural growth trends continue unchecked. In addition, the area is subject to high winds and flooding. Much of the growth in the last 10-20 years has been in response to white-collar economic development in research and government. Between 1960 and 1970, the population rose from 37.718 to $66.870--a n$ increase of $77 \%$.

Citizen and government action, in Boulder, resulted in response to the 1) high growth rate; 2) the heavily promoted land subdivision of mountains; 3) the rising costs of services; and 4) concern for preserving the "quality of life." Boulder sought to preserve the scenic mountains, restrain and compact development, and physically separate the city's growth from surrounding suburbs. The city wants to control the direction of growth and give the community the power of this control. In October of 1976. C1ty Counc1lman Paul Danish introduced a plan to preserve the "quality of life" in Boulder. 
(Danish Plan) The objective of this plan is to hold the growth rate of Boulder to $1 \frac{1}{2}$ to 2 percent a year. The Danish Plan consists of two ordinances. 28 The first is a $2 \frac{1}{2}$ page slow growth ordinance passed by voters in November 1976. It limits residential constmaction in the c1ty through a merit system for allocating a limited number of bullding permits for five years. Here are the main points of the ordinance: No more than 450 dwelling units, w1th limited except1ons, may be constructed per year. Counc1l has the authority to approve more than that in one year if the number is reduced by a like amount in the following years. It can reallocate any permits that have not resulted in actual construction within 15 months.

Council approval, by a majorlty vote, is required for any single project under whlch more than 75 dwelling units will be constructed.

No more than 275 units per year may be approved for fringe areas of the city. The remaining 175 permits, and any of the 275 not allgcated, may be approved for the core area of the c1ty.29

The November 2 ordinance exempts:

a. minor projects--4 or less single-family units;

b. multiple unit projects of less than 4 units;

c. single-family homes bullt on lots platted before November 10-when the election results were certified. 30

The second ordinance is a much longer merit allocation system adopted by the City Counc1l in March 1977. Merit system point scores were awarded in four basic categorles: (100 point system)

1) arailability of existing public facilities and services (30 points): 2) provision of low and moderate income housing (20 points); 3) environmental elements ( 20 points): 4) site design and relationsh1p w1th surrounding areas ( 30 points) 
Allocation of permits is administered on June 15 and in the middle of November after two six-month review cycles which end on Apr11 1 and october 1, respectively.

Reaction to the Danish plan is mixed. The following opinions are representative of this mix. City Councilman

Paul Dan1sh (proponent) states:

The comprehensive plan is a powerful land-use tool for directing where growth should occur, and for regulating population density levels. but it is not a growth control plan. It can help stop urban sprawl. but it does not state an annual growth rate or provide mechanisms to achieve a controlled growth rate. The comprehensive plan would stimulate growth without the controls provided by the Danish slow growth ordinance, and does not provide incentives for building moderate income housing. 31

Businessman Truman Anderson (opponent) states:

The Danish plan is driving up the housing prices. Consequently the plan is exclusionary. The comprehensive plan is adequate by itself to control future growth if properly implemented. The plan's capital improvement program can pace the city's ability to provide basic urban services before additional land is annexed, and thereby effectively control the rate of growth. I am not in favor of adopting a percentage or fixed number to set a population limit. Such absolutes would curtail future options. 32

Thus far, there has been no legal challenge to the plan

1tself. Developers of a proposed East Boulder housing project did file suit against the city of Boulder in district court (August 1977) challenging what they consider to be unfair restrictions imposed by the Danish slow growth plan.

Developers of the Meadow Glen project at 55 th and Baseline say in the suit that the city 'committed' itself to their Planned Unit Development (FUD) of 131 units on a 25-acre parcel before the Danish plan was approved by voters in last November's general elections. 
...At issue in the suit is City Attorney Walt Wagenhal's interpretation on whether developments such as the Meadow Glen project must go through a merit review system developed by the Planning Department to implement the Danish plan.33

But this is a question relating to procedure--not substance. The sentiment of the people in Boulder, reflected in the November 1977 municipal election, seems to say that they have had "enough"--enough expansion, enough people. enough of heading toward blg olty ways. The voters sald clearly that slower growth would mean a higher "quality of I1fe." 34

The preceding list of municipalities which have made efforts to control and regulate the timing and location of its private residential development is by no means comprehensive. The experience with growth control, especially in the Town of Ramapo, New York, and the C1ties of Petaluma, Cal1fornla and Boulder, Colorado has much to teach the student of modern land use policy. The lessons they exemplify highlight some of the 1ssues and problems which need to be addressed when developing a growth control plan.

c. Issues/Problems Encountered W1th the Management and Control of Growth at the Local Level

Much has been sald in the professional literature 35 and press $^{36}$ about the need to control unbridled growth and inadequate land use management. Th1s trend has not been w1thout opposition. Often, the basis for opposition evolves from the fact that the far-reaching repercussions of growth controls are not analyzed at length by those caught in the debate over the "quality of life." for their communities. The class of 
methodologies, tools, and systems--as well as the inherent legal, economic, administrative, and social questions--quite frequently are not subject to sufficient evaluation.

The local policy maker should analyze growth control(s) or growth management systems in terms of their "cumulative" impacts, including:

1) the distortion-effect on local/regional demographic and market trends;

2) the extra-jurisdictional or extemality effects;

3) the external effects on the socifl/economic system:

4) community motivation or intent. 37

Does a growth control ordinance interfere with a person's constitutional right to travel and live where they wish? (Petaluma) What is the effect of a local growth control ordinance on the region? Should not a more broadly based land use decision-making process be established to deal with what is essentially a regional problem? (Ramapo) Does a local growth management scheme push up the price of housing while threatening to price a large class of citizens out of the municipality? (Boulder) Does the plan threaten to destroy the social environment of the locality just as certain as uncontrolled growth would destroy the physical environment?

Growth restrictions can force increased separation between place of residence and primary employment centers, thereby increasing commuting costs and foreclosing various job opportunities for persons unable to absorb the higher costs or to utilize altemative transportation modes. The supplier of housing--the residential construction company--may experience a major squeeze, slowing the con- 
struction of new units for an extended period of time.

A major problem of many growth management decisions is the fact that they are made solely on the basis of fiscal issues (taxes, quality of public services) w1th growth being rejected because of direct "costs," etc.; such emphasis can lead to a distortion in proper land use management. There are also socio/environmental 1ssues. 38

What about equity issues? There is nothing to make the average locality plan for growth and housing which it does not want. This brings us to the question: why was the growth control system instituted in the first place? Is it arbitrary, unreasonable, and exclusionary in 1ts effects?

Affirmative social programs must be implemented to ameliorate the difficulties with growth management.

Growth management ralses some bas1c legal 1ssues. 39 one issue evolves around the use of "police power." The basic question 1s: can the police power, which is delegated by the state, be exercised solely for the benefit of the residents of the locality and with minimum regard to the housing and other needs of the citizens in the larger region? or is there a "reglonal" context to the local use of police power.

The equal protection question raises two basic sets of challenges. The first involves allegations that the application of a regulation, or the regulation itself, bears no reasonable relation to a permissible government objective and that it has been inequitably administered. The second concerns whether a suspect classification or a fundamental interest is involved. 
The "taking" 1ssue evolves around the question of whether a government regulation so interferes w1th the use and enjoyment of private property that there is necessitated a public payment of just compensation to the owner due to a "taking." It involves a question of degree.

Another classic constitutional challenge is that an ordinance, decision, or other government action constitutes a violation of federal or state guarantees of due process. Historically, due process has been seen from two perspectives: the right to "procedural" due process, and "substantive" due process review by the judiclary. Procedural due process is most commonly violated when the local government, for example. falls to give adequate notice to all affected parties or ignores the requirements of fair hearings such as the right to be heard and to present evidence. "Substantive" due process-"content analysis" and a welghing/balancing of the validity of the regulation itself--is a somewhat questionable theory of the constitutional interpretation, suggesting, in effect, a review of the inherent validity of a decision/regulation in certain circumstances and the "balancing" of various substantive considerations by the judiciary.

To sum up, techniques for managing growth, such as timing/phasing. necessitate that the local official or citizen apply considerations of legal, social, economic, fiscal, and administrative factors. One must ask: are the techniques defensible, and from which points of view? Or, has the decision-making process at least made these elements an explicit 
part of the analysis before arriving at policy trade-offs and conclusions? And finally, has the municipality made a serious effort to deal, on a regular basis, with the tools that are currently and prospectively avallable to 1 t? 
EN DNOTES

1. Hans Blumenthal, "The Role of Design," AIP Journal. September 1967). p. 305 .

2. Alvin Toffler. Future Shock, Random House, New York, 1970.

3. Barry Commoner. The Closing Circle. (Ist. Ed.) New York: Knoff. 1971.

4. 42 U.S.C. 4332 .

5. Hans Blumenthal. op. c1t.. p. 309.

6. Robert Cahn, "Where Do We Grow From Here?" Volume I. Management and Control of Growth. Edited by Randall W. Scott and David J. Brower and Dallas D. Miner. 1975. The Urban Land Inst1tute, Washington, D.C., p. 62.

7. Hyung C. Chung (U. of Bridgeport, Conn.). "Regulating The Timing of Residential Development-The Ramapo Study." paper submitted for presentation at Confer-in 72 .

8. Charles Haar, Land Use Planning: A Casebook on the Use. Misuse, and Re-use of Urban Land. Second Edition. Boston: I1ttle. Brown and Company. 1971. Chapter 4, Regulating The Tempo and Sequence of Growth by Subdivision and Street Controls.

9. Henry Fagin. "Regulating The Timing of Urban Development," Law and Contemporary Problems. Vol. 298 (1955). p. 296.

10. Ibid.. pp. 298-299.

11. Stephen I. Urbanczyk, "Phased Zoning: Tempo/Sequence of Development," Volume II, Management and Control of Growth. Edited by Randall W. Scott and David J. Brower and Dallas D. Miner. 1975. The Urban Land Institute. Washington. D.C.. P. 415 .

12. Hyung C. Chung. op. c1t.. p. 2 .

13. Ib1d.. p. 2 .

14. Ib1d.. p. 3

15. 24 M1sc. 2d. 366. 198 N.I.S. 2d. 695. Super1or Court. Rockland County. 1960.

16. Norman W1Il1ams. The Structure of Urban Zoning and Its Dynamics in Urban Planning and Development. New York: Buttonheim Publications Corporation. 1966. 
17. American Society of Planning Officials, Planning Advisory Service, Report Nos. 309. 310. "Urban Growth Management Systems." pp. 22-23.

18. Ibid.. p. 23.

19. Golden V. Planning Board of the Town of Ramapo. $285 \mathrm{~N} . \mathrm{E}$. 2d. at 304-305 (1972).

20. Golden, at 302 .

21. ASPO, Report Nos. 309, 310, pp. 18-19.

22. Ibid., p. 19 .

23. Construction Industry Association of Sonoma County v. City of Petaluma. 375 F. Supp. 574, 6 ERC 1453 (N.D.Cal. 1974).

24. 375 F. Supp. at 586.

25. $522 \mathrm{~F} \mathrm{2d.} \mathrm{897.} 8$ ERC 1001 (9th C1rc. 1975) cert. dented. 96 s.Ct. 1148 (February 23, 1976).

26. 522 F. 2d. at 908-909.

27. 522 F. 2d. at $908 \mathrm{n} \cdot 16$.

28. See Appendix for the two ordinances.

29. Boulder Da1ly Camera, Wednesday, April 20, 1977. "How W11l Danish Plan Affect County?"

30. Boulder Daily Camera, Friday, February 25, 1977, Steve Hoffman. "Planners Accept Permit System."

31. Colorado Daily, October 1977. Stephen Foehr, "C1ty council candidates divided on growth control question."

32. Ibid.

33. Boulder Da1ly Camera, August 1977. "Sult Challenges Dan1sh Merit System." by BIII Cont1 and Steve Hof fman.

34. Boulder Daily Camera, November 1977. "Voters Seem to Say "Enough'." by Robert Ruby.

35. See: "Nongrowth as a Planning Alternative: A Preliminary Examination of an Emerging Issue," by Earl Finkler. ASPO Planning Advisory Service, Report Number 283-Sept. 1972; and. "Managing Growth: Report of the ICMA Committee on Growth and the Environment." September 1973. Public Management (monthly magazine of International $C_{1}$ ty Management 
Association, 1140 Connecticut Arenue, N.W.. Washington, D.C. 20036).

36. See Robert Cahn, "Where Do We Grow From Here?"--footnote 6.

37. Volume I, Management and Control of Growth. Edited by Randall W. Scott and David J. Brower and Dallas D. Miner, 1975. The Urban Land Institute, Washington, D.C.. p. 10.

38. Ib1d.. p. 14.

39. Ib1d., pp. 17-21. 
CHAPTER TWO

JUSTIFICATION FOR UTILIZING A GROWTH

CONTROL STRATEGY IN NORTH KINGSTOWN

North Kingstown is a growing rural-suburban town which faces many of the problems discussed in Chapter One. For general orientation, see the regional map and the base map on the following pages. As residential expansion increases in North Kingstown, one hears of numerous concerns. Some people claim that North Kingstown has grown enough, yet subdivisions continue to appear. Town officials and citizens allke express concern about the avallability and quality of services. There seems to be a hope from certain groups that growth will stop or occur very slowly. Others recognize rapid growth but are unsure of which appropriate planning policies to pursue. The town Zoning ordinance recognizes the need to carefully manage growth. However, the ordinance cannot control where residential development will occur (inasmuch as it occurs in a residential zone). The developer can still theoretically build wherever he wishes without a great deal of attention to avaliability of services.

North Kingstown is a town with considerable developable land. Approximately 2,800 acres $^{l}$ of vacant land were avallable for residential development in 1978. Like any town with avallable vacant areas, some of the locations are more suitable 


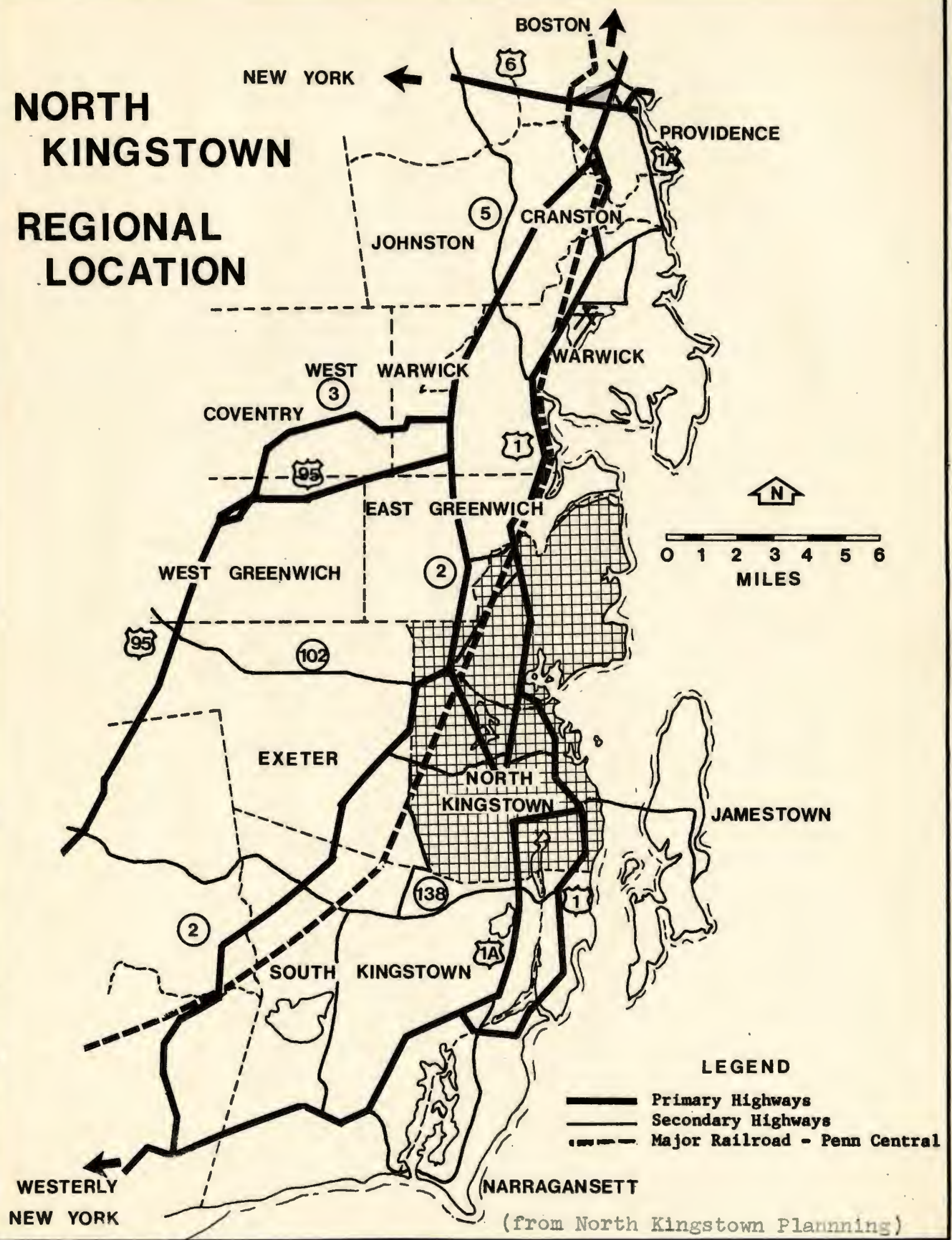




\section{NORTH KINGSTOWN}

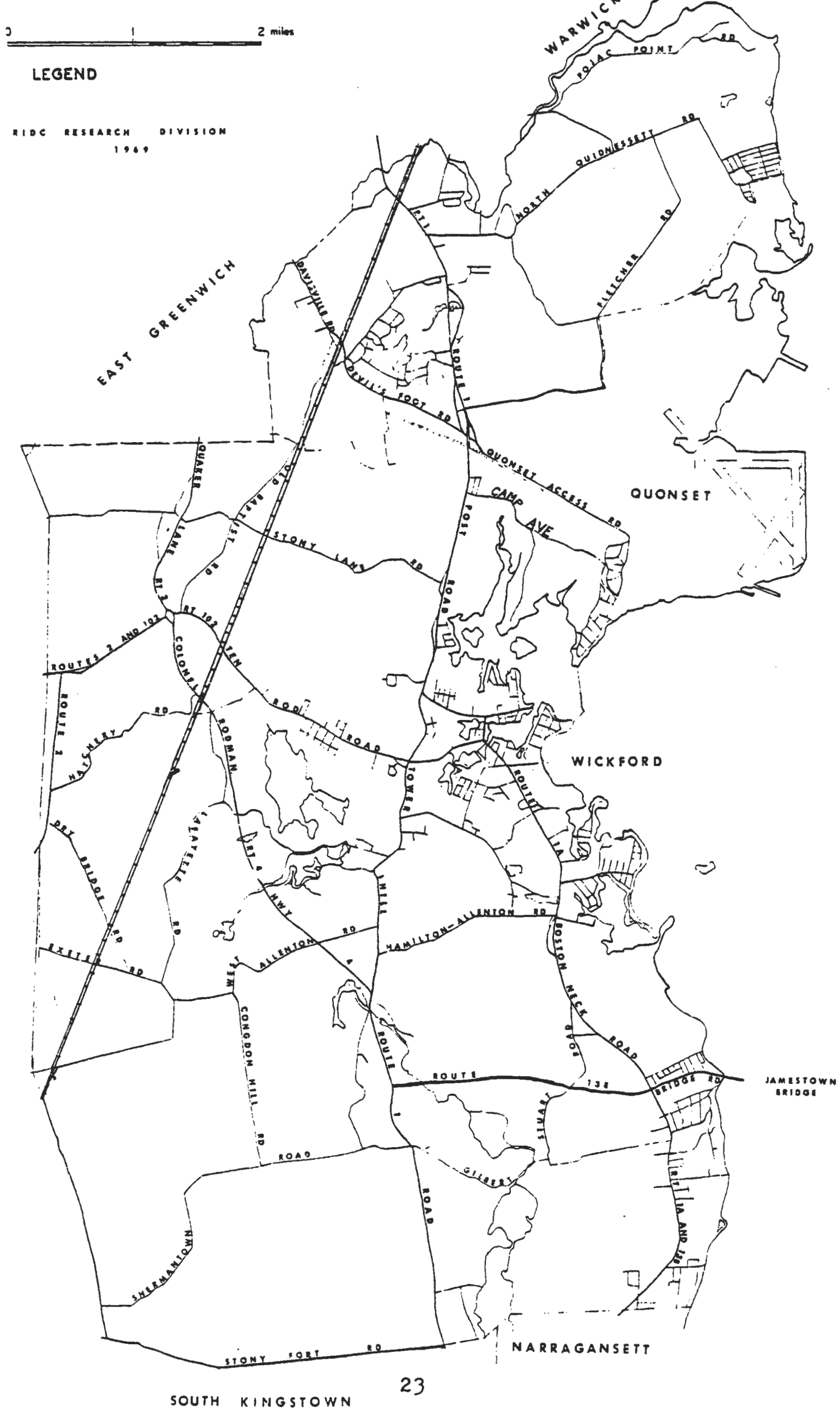


for development than others. Land is a valuable resource and it is important, as mentioned, that North Kingstown plans for 1ts present and future use responsibly.

In general, a growth control strategy would be suited to the above goal, to ensure proper development of remaining vacant land (an example of improper development would be scattered development with little attention paid to the availability of services).

In North Kingstown there is presently no growth control plan. At the moment, the town uses a permit-by-permit policy whereby the building inspector reviews each application for a building permit. A developer's plan must also be in accordance with the zoning ordinance, sub-division regulations, or state land-use regulations if applicable (for example, sept1c systems must meet state guidelines). It cannot be said that the present permit procedure is inadequate or not working. It can be argued that such a system is limited in its capacity to address future development problems. As it stands, the permit system fails to consider future needs such as the avallability of services to support new residential developments. Overall, the system fails to incorporate a more comprehensive procedure of permit approval with sound local land-use and financial planning. In essence, the town has no sure method of knowing in advance where new residential development will go, when it w1Il appear, and whether or not the services (1mproved roads, sewers or septic systems, schools, fire protection, etc.. etc.) w1ll be there to support the development. 


\section{5}

North Kingstown can begin to take a more futuristic (short range outlook, fifteen years) view of residential development or 1 t can continue with 1 ts present day-to-day permit procedure. As a growing area, with substantial prime developable land, North Kingstown may want to consider the use of a growth control strategy to guide 1 ts future residential development. The following discussion should further substantiate the use of a growth control plan for North Kingstown.

There are five areas of concern that justify the adoption of a growth control plan for North Kingstown. They are, population projections, bullding permit data, the need for a capital improvement program, in more general terms, the recommendations of the proposed Rhode Island Land Management B111. and the need to promote energy efficient design and protect fragile areas.

There are many reasons why a town or c1ty might institute a growth control plan. Certainly population increase can be an influencing factor as it was in Ramapo. New York and to a lesser degree in Petaluma, Califormia. In Ramapo, N.Y., between the years 1960-1968, the population almost doubled (from roughly 35,000 in 1960 to 66,000 in 1968). ${ }^{2}$ Granted. th1s was a phenomenal period of growth. North Kingstown is not expected to experience a similar occurrence. Nevertheless, when compared with other Rhode Island citles and towns, North Kingstown's population is projected to grow the most rapidiy over the fifteen year period between 1975-1990. Statewide Planning was consulted for population pro- 
jections. ${ }^{3}$ Their projections are as follows. Notice that North Kingstown shows by far the largest total increase and percent change between 1975-1990.

\section{TABLE I}

R.I. POPULATION PROJECTIONS FROM 1975-1990 FOR SELECTED CITIES AND TOWNS (in thousands)

\begin{tabular}{|c|c|c|c|c|c|c|}
\hline \multirow[b]{2}{*}{ Town or city } & & \multirow{2}{*}{$\begin{array}{c}\text { total } \\
\text { increase }\end{array}$} & \multirow{2}{*}{$\frac{6-\text { chang }}{75-90}$} \\
\hline & 1925 & 1 & 1985 & 1990 & & \\
\hline $\begin{array}{l}\text { NORTH KINGSTOWN } \\
\text { Johnston } \\
\text { East Providence } \\
\text { East Greenw1ch } \\
\text { Warw1ck } \\
\text { Cranston } \\
\text { M1ddletown } \\
\text { South Kingstown }\end{array}$ & $\begin{array}{l}20 . \\
23 . \\
50 \\
10 \\
88 . \\
77 . \\
15 . \\
21 .\end{array}$ & $\begin{array}{l}25 . \\
27 \\
54 . \\
11 . \\
93 . \\
81 . \\
16 . \\
21 .\end{array}$ & $\begin{array}{l}32.5 \\
30.5 \\
57.0 \\
12.1 \\
99.0 \\
85.0 \\
17.6 \\
22.0\end{array}$ & $\begin{array}{r}40.0 \\
31.5 \\
62.3 \\
12.6 \\
103.6 \\
89.0 \\
18.3 \\
23.0\end{array}$ & $\begin{array}{r}20.0 \\
7.7 \\
11.5 \\
2.0 \\
14.9 \\
12.0 \\
2.7 \\
1.9\end{array}$ & $\begin{array}{r}100.0 \\
32.4 \\
22.6 \\
18.9 \\
16.7 \\
15.6 \\
10.9 \\
9.0\end{array}$ \\
\hline
\end{tabular}

The possibility of North Kingstown doubling their population in just fifteen years should certainly have town officials thinking about appropriate growth control strategies. Another 1mportant growth indicator for a town or city is its residential building permit data. A growing area can logically be expected to be adding an increasing number of dwelling units from year to year. Th1s has generally been the case in North Kingstown since 1974, the first year after the Navy pull-out. The chart below shows that North Kingstown experienced a dramatic increase in new housing units (authorized by bullding permits) in 1977. In fact, North Kingstown authorized almost as many new housing units in 1977 as compared to the total number of permits for the three previous years combined. In addition, between January-March, 1978, North Kingstown had issued more bullding permits than any Rhode Island 
town or city, according to the Providence Sunday Jourmal. Business Section, April 23, 1978.

\section{TABLE II}

NEW HOUSING UNITS AUTHORIZED BY BUILDING PERMITS IN NORTH KINGSTOWN 1973-1977

total units 1973

increase total total 6 \%increase units change change 8,182 $\begin{array}{lll}1974 & \frac{1975}{88} & \frac{1976}{80} \\ 105\end{array}$ 1977 $73-27$ $1972 \quad 76-72 \quad 73-72$ 252 525

$8.707 \quad 2.98$ 6.4

When compared with other suburban towns and c1ties in Rhode Island, North Kingstown saw the largest percentage increase, except for North Providence, in new dwelling units between 1976-1977.

\section{TABLE III}

NEW HOUSING UNITS AUTHORIZED BY BUILDING PERMITS FOR SELECTED CITIES AND TOWNS IN R.I., 1976-1977

\begin{tabular}{|c|c|c|c|c|}
\hline C1ties and Towns & $\begin{array}{c}\text { total undts } \\
1976\end{array}$ & $\begin{array}{c}\text { Increase } \\
1972 \\
\end{array}$ & $\begin{array}{c}\text { total units } \\
1977 \\
\end{array}$ & $\begin{array}{c}8 \text {-change } \\
76-27\end{array}$ \\
\hline $\begin{array}{l}\text { North Providence } \\
\text { NORTH KINGSTOWN } \\
\text { Coventry } \\
\text { South Kingstown } \\
\text { Warw1ck } \\
\text { East Providence } \\
\text { Cranston }\end{array}$ & $\begin{array}{r}10.452 \\
8.455 \\
8.311 \\
7.304 \\
31.239 \\
17.243 \\
25.585\end{array}$ & $\begin{array}{l}370 \\
252 \\
183 \\
153 \\
555 \\
332 \\
227\end{array}$ & $\begin{array}{r}10.822 \\
8.707 \\
8.494 \\
7.457 \\
31.794 \\
17.575 \\
25.812\end{array}$ & $\begin{array}{l}3.5 \\
2.98 \\
2.2 \\
2.1 \\
1.8 \\
1.3 \\
0.89\end{array}$ \\
\hline
\end{tabular}

There are those who may have been led to belleve that the Navy pull-out would result in a declining growth patterm for North Kingstown. Yet, the population projections and building permit data indicate otherwise. In light of the pullout, this growth trend seems all the more impressive. If 1977 
was any indication of what lies ahead for North Kingstown, now would be an appropriate time to consider a residential growth control plan.

While the above data supports a growth trend for North Kingstow, its proximity to other growing and developed suburban areas could have spin-off effects on the town as well. It has been argued that North Kingstown could be the next town in line. moving outward from Providence, to experience rapid suburbanization. In this manner. it would follow the growth and development of Cranston and Warwick.

As explained in Chapter One, there are various types of growth controls or land management policies and strategies. One type, as used in Ramapo, N.Y.. attempts to phase development in conjunction with the capital improvement program. Presently, North Kingstown has no working capital improvement program. Instead, the town has opted for an incremental approach to capital improvements.

As with the procedure for the approval of residential development permits, this kind of financial planning is rather short sighted. Economists and planners have referred to this type of financing as a "pay-as-you-go" method. In other words. this results in services following development rather than development occurring after the services are there to support 1t. And if development is allowed to occur anywhere within North Kingstown. suburban sprawl could prevall. The town may find itself in the unfortunate position of being unable to supply all areas with adequate services. The inevitable 
burden on the tax base and expenditures could be overwhelming. The suggestion for sound fiscal planning in North Kingstown is not a new one. In 1972, the town's Master or Community Development Plan recommended it as well. Under the "Goals and Policies" section, the plan set forth as the first 8oal:

1. Controlled Town Growth - The town should grow only at the rate it can meet the growing demand for services and finance necessary capital construction.9

In the "Implementation" section under "Capital Expenditures," the Plan further substantiates the case for a capital improvement program.

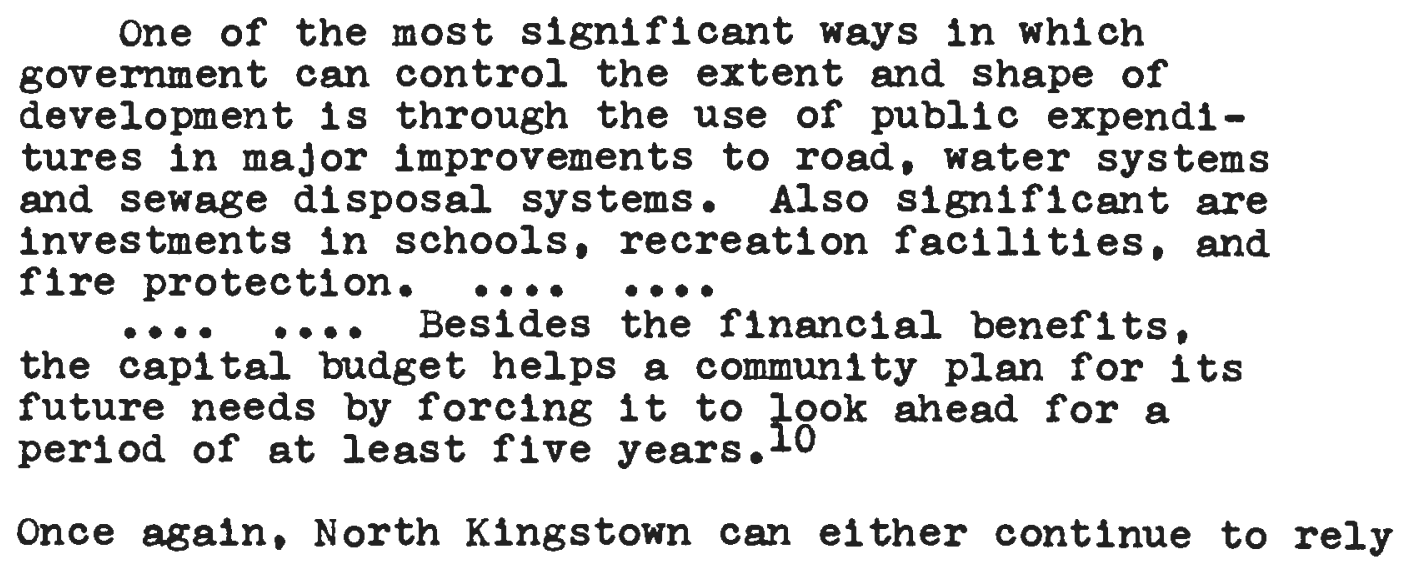

The fourth Justification of utilizing a growth control strategy for North Kingstown can be found in the proposed R.I. State Land Management Act. Generally speaking, the recommendations of the bill could apply to any $R . I$. city or town. Yet, it is important that the bill allows for growth control methods to be used at all. The present Zoning Enabling 
Legislation, in all likelihood, would not allow growth control (see Appendix $B$ on Legal Considerations).

The bill finds that land is a "finite natural resource" that must be properly guided and managed. It warns that haphazard scattered development can result in "increased service costs and loss of open space." It also suggests that the location of development should be carefully planned with due consideration to the "required level and cost of public services." To insure against haphazard development the bill allows for "the proper scheduling and staging of development to ensure adequate open space and public facilities." North Kingstown may find it both helpful and advisable to follow the bill's recommendations.

The final justification for utilizing a growth control program in North Kingstown concerns the protection of environmentally fragile areas and the need to promote energy efficient housing design. The town must protect its valuable groundwater supply, build on 1 ts more dralnable solls and conserve energy whenever possible.

A growth control plan for North Kingstown forces the town to consider where it has been. where it is going, and how it wants to get there. In essence, the Community Development Plan of 1972 already followed through with this sort of planning process. Some trends in North kingstown have abruptly changed since then, others very little or not at all. A growth control plan and/or ordinance which would time or phase 
31

the residential development of North kingstown could be just the vehicle to begin to put (those relevant sections of) the Community Development Plan 1nto action. The next chapter w1ll explain the specific growth control methodology that we propose for North Kingstown. 
1. The sources used to compute this figure were: The North Kingstown Planning Department. Community Development Plan. North Kingstown, Rhode Island, September, 1972, p. 50. The Urban Design Group. Inc.. North Kingstown Housing Element. 1975. p. 6. Rhode Island Department of Economic Development. Rhode Island Bastc Economic Statistics... the economy, summary and trends. 1977-1978, p. 92 and 97. The Providence Sunday Journal. Business Section. p. F 9. Jan.. 22. 1978 .

The 2,800 acres of vacant land available for residential development is a rough approximation. (I) First, we computed the area in acres for single family units in 1978. As of January 1. 1978 there were 5.608 single family units in N.K. So. 5.608 units X.52 (avg. units per acre) $=2.916$ acres. (2) Then, we computed the area in acres for duplex and multi-family units as of 1978. As of January 1, 1978 there were 2.458 (authorized by building permit) duplex and multi-family units. So. 2.458 units $X .26$ (avg. units per acre) $=639$ acres. (3) We estimated the less significant acreage increase for seasonal, moblle homes and estates. Total residential acreage $=4.592$. (4) We updated the acreage increase for 1ndustrial and commercial uses, as well. (5) Next. we updated the flgures for total acreage of developed and vacant land, roughly 17.416 acres and 10.840 acres. respect1vely. (6) As of January 1, 1978, 26.4\% of the total developed land was devoted to residential development $(4,592$ acres of residential land divided by 17.416 of developed land $=26.4 \%$ ). (7) Using the $26.4 \%$ as a general reference for residential development, we multiplied 1 t by 10,840 acres to get 2.860 . (8) We assumed that the percentage of land devoted to residential development would remain about the same, at $26.4 \%$. (9) We then adjusted the 2.860 acres to 2.800 acres to take into account land with a slope in excess of $15 \%$.

2. Hyung C. Chung, "Regulating the Timing of Residential Development, the Ramapo Study." submitted for presentation at Confer-1n 1972, p. 6.

3. We also consulted the population projections of The Department of Economic Development (DED). Their projections were lower than those of Statewide Planning. However. In a telephone conversation with an officlal at DED, the person explained that their department's projections were not as detalled as those of Statewide Planning. Therefore. we used Statewide's projections.

4. Rhode Island Statew1de Planning. Rhode Island Population Projections by County, C1ty and Town. Technical Paper Number 25. Apr11, 1975. p. 20 
5. The Rhode Island Department of Economic Development, op. o1t.. p. 49 .

6. The Providence Sunday Journal. op. c1t.. p. F 9.

7. Department of Economic Development, op. c1t.. p. 49.

8. The Providence Sunday Journal, op cit.. p. F 9.

9. The North Kingstown Planning Department, op. c1t.. p. 158. 10. Ibid., p. 180 . 
CHAPTER THREE

GROWTH CONTROL METHODOLOGY

As Chapter One noted. there are various types of growth control programs. Chapter Two went on to justify the strategy of using a growth control program in North Kingstown. Chapter Three will explain the specific type of growth control program that we have developed for the Town.

The chapter will consist of five topic areas. The first section (introduction), will offer a general discussion of the particular point system we have developed. The discussion will also focus on the various components of the system and the philosophy behind the point system. The second section will describe in general, the components of the "Public Facilities" category. Included in this section will be a discussion and presentation of our proposed fifteen-year Cap1tal Improvement Program. The third section will offer a discussion on energy conservation and the role of local government. The discussion will also include a general description of the elements of the "Energy" category. The fourth section of the chapter will discuss low and moderate income housing needs in North Kingstown. In addition, this section will describe the particular components of the "Low and Moderate Income Housing" category. The fifth and final area of discussion will present suggested "Remedies" available to the 
Town, landowners, and consumers. The "Remedies" section is based on the assumption that North Kingstown would adopt the point system as part of their Zoning ordinance.

A. Introduction

The point system is designed to ensure; that residential development will occur only after the services are avallable to support 1t, that energy elements will be considered in the site and design of housing, and that the Town will meet 1 ts low and moderate income housing needs.

The rationale for using a point system has basically come from the growth control ordinances of Boulder, Colorado and Ramapo, New York (both ordinances are part of larger zoning ordinances). Officials in Ramapo and Boulder, concerned with rapid growth, developed different methods to control growth by requiring developers to consider an adequate provision of municipal services. Boulder took a more comprehensive approach by encouraging developers to consider energy factors and lower income housing needs as well. To realize their goal. Boulder and Ramapo developed "point systems" whereby those developers, who accumulated a certain number of development points, would recelve the special permit. It should be noted that Boulder's program was based upon a relative point system. There was no absolute number of points required for a special permit, as in Ramapo. Our system has attempted to combine the best of both systems. Why should the point system be incorporated into the 
zoning ordinance? It has been noted that zoning is static in nature and attempts to lump all land in a given town into a few broad categories. On the other hand, it has been argued that towns and their neighborhoods are dynamic in nature, especially growing areas. As K1rk W1ckersham, Jr.. has noted, a more comprehensive approach to zoning and permit systems is needed. ${ }^{1}$ The point system could better address such 1ssues as rapid population growth, the energy crisis, and low and moderate income needs--1ssues that the zoning ordinance wasn't really designed to handle. As part of the zoning ordinance, the point system would carry the legal authority of this document and provide a more encompassing, dynamic approach to development 1ssues. It should be pointed out that the point system would not replace the present zoning ordinance, subdivision regulations, general building permit procedures or any other applicable state or town codes. Its purpose is to work with the Town's Comprehensive Plan and various existing regulations, codes or ordinances.

The basic methodology of our growth control ordinance consists, as mentioned, of a point system for residential development. This point system will be based upon the availability and consideration of public facilities, energy elements, and low and moderate income housing needs. As in Ramapo. New York, the capital 1mprovement program will be sequenced with development. In other words, the ability of a developer to secure the standard number points will be contingent, in part. on the Town's or developer's abllity to provide public facili- 
ties (See the discussion of the Capital Improvement Program). our point system is actually divided into two subsystems, an elghty (80) point system and a one hundred (100) polnt system. The developer w1ll be required to accumulate $65 \%^{2}$ of the total points for elther sub-system. Those developers who wish to construct development or developments other than low and moderate income units, will be eligible to accumulate eighty $(80)$ points based upon public facilities and energy elements. In this instance, the developer will be required to accumulate fifty-two points (52), (or 65\%), of the total elghty $(80)$ points. Those developers who plan to construct any number of low and moderate income units will be judged on a one hundred (100) point system based upon all three categories. In this case, the developer will be required to accumulate sixty-five points (65), or (65\%), of the one hundred (100) total points. Note that when low and moderate income housing limits (See Section $D$, Low and Moderate Income Housing), have been satisfied, the point system will return to an eighty (80) point system based upon the public facilities and energy elements. Those developers who accumulate the standard of $65 \%$ of the total points or higher w1ll automatically recelve their special permit.

Finally, we urge that the point system be properly administered. It should never be used as an exclusionary device or a method for the town to collect exorbitant and possibly 1llegal development charges. We assume that North Kingstown would give their best effort to properly manage such a growth control program. 
B. Public Fac1lities

The purpose of the "Public Facilities" category is to ensure that development will follow the avallability of municipal services. The components of this category include a broad range of services such as Police protection. Fire protection, water distribution, etc.. etc. The entire list of criteria can be seen in the Model Growth Control Amendment in Appendix A or in Figure I, page $38 \mathrm{~A}$.

Another important aspect of the "Public Facilities" category is its relation to the proposed Capital Improvement Program. As mentioned, a developer's abllity to secure points is contingent, in part, on the Town's ability to provide capital improvements.

As housing construction in North Kingstown continues at a rapid pace. it becomes increasingly important to plan ahead for the new development. Otherwise, the town may soon face an overload on present systems and a resulting insufficient supply of services to meet the new demand. The Capital Improvement Program will enable the town to better control and plan for 1ts future growth.

The development of a town's capital improvement program is often a detalled. sophisticated plece of work. Each department should first prepare a careful study of expected future needs. Secondly, the mayor or town manager might prepare his or her own statement of needs or requests. Next, the above official attempts to piece together (drawing upon the depart- 
F18. I

Public Facilities criteria

To encourage development on sites already served by existing utilities and services. Or to encourage developers to walt for the necessary improvements or to supply them themselves. (Maximum fifty (50) points).

5 pts. - A. State, County, or Town Major Secondary or Collector Boads

5 pts. - direct access

3 pts. - within $\frac{7}{2}$ mile

1 pt. - within 1 mile

0 pts. - further than $1 \mathrm{mile}$

5 pts. - B. Improved Public Park or Becreation Facility including Public School Site

5 pts. - within mile

3 pts. - within mile

1 pt. - within 1 mile

0 pts. - further than $1 \mathrm{mile}$

5 pts. - C. Fire Protection

5 pts. - within 1 mile

3 pts. - within 2 miles

1 pt. - within 3 miles

0 pts. - further than 3 miles

5 pts. - D. Water Distribution

5 pts. - existing water mains and water system meet town standards for water service and fire protection, or such improvements are provided by the town at some point during the fifteen year Capital Improvement Frogram.

3 pts. - such 1mprovements are provided by the landowner or developer.

0 pts. - where the above conditions are not met.

5 pts. - E. Sewers

5 pts. - public sewers avallable

3 pts. - state approved septic systems

3 pts. - package sewer plants

0 pts. - all others

5 pts. - F. So1l Constraints

5 pts. - slight

3 pts. - Moderate

1 pt. - Severe

0 pts. - Very Severe 
5 pts. - G. Police Protection

$$
\begin{aligned}
& 5 \text { pts. - development can be served by the } \\
& \text { existing personnel and facilities, } \\
& \text { and is within the existing service } \\
& \text { routes. } \\
& 0 \text { pts. - development can be served by the } \\
& \text { existing personnel and facilities } \\
& \text { but an expansion of service routes } \\
& \text { is necessary. }
\end{aligned}
$$

4 pts. - H. Flood Control

4 pts. - if development is not in the flood plain or if it 1s, the town proposes to construct the necessary drainageway ( $s$ ).

2 pts. - if the developer proposes to construct the necessary drainageway (s).

0 pts. - if the development is in the flood plain and proposes no mitigating measures.

4 pts. - I. School Capacity

4 pts. - if a school serving the development is within $2 \frac{1}{2}$ miles and will not exceed the capacity limits of that facility.

2 pts. - if a school serving the development is within 5 miles and will not exceed the capacity limits of that facility.

0 pts. - if the development exceeds the capacity limits of the school serving it and/or is more than 5 miles away from that facility.

4 pts. - J. Storm Drainage

4 pts. - local drainage generated by the development will require no additional public improvements in order to carry the runoff to a receiving drainageway, or the town will provide the necessary improvements.

2 pts. - the developer will provide the additional public improvements that are required to carry the drainage generated by the development, 1.e., catch basins, inlet structure, etc., to a receiving drainageway .

0 pts. - where the above conditions are not met. 


\section{$38 \mathrm{C}$}

3 pts. - K. Public Transportation

3 pts. - existing bus service is within mile of the development.

1 pt. - existing bus service is within $\frac{1}{2}$ mile of the development.

o pts. - existing bus service exceeds $\frac{1}{2} \mathrm{mile}$ from the development. 
mental requests) what he or she feels the town w1ll realist1cally need in the years ahead. once this is completed, the town counc1l w1ll offer its criticisms and recommended changes in the program. Following this, the town residents either vote to approve or reject the program. Future town meetings and voting may be needed to eventually work out any conflicts. In putting together our Capital Improvement Program. we were able to secure the Town Manager's proposed six year Cap1tal Improvement Program (1978-1984) and departmental requests over the same six year perlod. We decided, based upon the avallability of information, to use the Town Manager's proposal for the first six years of our fifteen year program. It should be pointed out that the Town Manager's proposal is based upon capital needs and isn't necessarily influenced by residential development patterns. However, developing a capital improvement program based upon present and future residential development policies is crucial to our growth control plan. If and when North Kingstown decldes to adopt such a growth control plan, capltal improvement programs will have to consider desired residential growth patterns. The remaining years and capital 1 tems of our Capital Improvement Program are based upon overall need and present and future residential growth considerations. (There are a few capital 1 tems proposed within 1978-1984 that are not part of the Town Manager's proposal, as noted in the schedule if improvements. These 1 tems are based on need and residential development patterns as well.). In proposing these 1 tems, 
we attempted to secure the necessary information from the various departments within town. The following explains how we compiled our data.

Our first step consisted of sending letters to the varlous departments within the town (Public works, Recreation, Police Dept., Fire Dept., Town Engineer, and School Dept). In this letter we requested each department to attempt to project where and when new fac1lities would occur in town over the next fifteen year period, based upon present residential and future desired residential growth areas. We provided each department with Statewide Planning's population projections and a base map to indicate where new facilities might go. Next, we followed up the letters with a visit to each department to discuss our study and specific requests. The information we were able to secure from the different departments varied considerably. Some officials were reluctant to propose any new 1mprovements, taking a no growth stand on the 1ssue. Other departments were able to supply us with rather extensive information. The following is a brief summary of what we were able to find out from each department.

The Recreation Department was able to supply us with a great deal of information. They were also able to show us the general location of expected new facilities from both a short range and longer range point of view.

The School Superintendent was able to show us the exact location of new school athletic additions under construction. He was hesitant to offer us any long range school plans because 
of certain reports that forecast a declining school age population for North Kingstown through 1993. However, he had his doubts about these studies because of the obrious high number of housing starts occurring in the town. If population projections prove to be accurate it is apparent that new schools or a new school will be needed. We hesitated to include any new facilities in our Capital Improvement Program because we received no information to base such a decision upon.

The Town Engineer was unable to supply us with any long range plans. However, he did say that the sewer referendum of 1977 or something similar might realistically pass within five to eight years.

The Director of Public Works said the Town's water system was adequate for the next fifteen to twenty years. He concluded that no major improvements would take place.

Unfortunately the information we needed from the Police Department, concerning service districts and routes, was not available for public use. To alleviate this problem we made certain assumptions as can be seen in Appendix $C$ at the end of this report.

We were unable to receive information from the Fire Department. However, in falmess to the Fire Department, we were able to get an idea of this department's future needs through information gathered for the Municipal Impact Evaluation System Study, (MUNIES, see below).

The MUNIES study is a report that a North Kingstown planning intern ${ }^{3}$ worked on with a private consulting firm 
(T1schler, Marcou and Associates, Inc.) from Washington, D.C. In essence, the study w1ll reveal the types of services that the town w1ll need in the future. The study w1ll project two different scenarios of development for North Kingstown. One projection would be based on the assumption that the Quonset/ Davisville land would be re-used. The second scenarlo would assume future service needs w1thout the re-use of Quonset/ Davisville. At the time of this writing, the town is still walting for the results of the study. We were able to secure some of the information from the student intern. Some of the information we sought was, in fact, already put together by Mr. Alo1sio in the summer of 1977.

Given time constraints and the amount of information we were able to obtain, we have developed a rough, yet workable fifteen year Capital Improvement Program broken up into three five year plans. The reader should bear in mind that the following schedule of capital improvements, while as realistic as possible, are mainly used for lllustrative purposes. Th1s Cap1tal Improvement Program's primary function is to 1llustrate to town administrators how it would operate in conjunction with the growth control methodology or point system. Its secondary function is to offer a general reference for future town needs, in part.

There are four general assumptions that the reader should be aware of before viewing the Cap1tal Improvement Program.

(1) The costs of many of the projects assume a constant level 
of services. The figures do not take into account inflation and other economic trends.

(2) Except for the Town Manager's proposed Cap1tal Improvement Program (denoted by the letter " $a$ "), other projects only consider those facilities mentioned in the point system in Appendix A under "Public Fac1lities." In other words, we projected only those needs that would be part of the point system. We purposely omitted other capital 1tems, such as the remodeling of a town bullding or the re-painting of highway lines, which didn't fall under the polnt system, although the town may certainly need at some point in time.

(3) In some areas, the proposed Cap1tal Improvement Program presents what may be needed and/or desired but may not be politically feasible or within the interests of all people. The proposed sewer project or the community center might be such an example, (see the proposed Cap1tal Improvement Program on the following pages).

(4) We assume the Town would adopt our Capital Improvement Program or something similar as official policy.

Key to Proposed Capital Improvement Program

a) project and cost were taken from the Town Manager's proposed Capital Improvement Program (1978-1984).

b) project and cost were taken from departmental requests during the above six year period (1978-1984).

c) project and cost came from the Recreation Dept. A possible source of funding could be through federal Community Development (CD) funds.

d) project and cost came from the MUNIES data. 


\section{4}

e) cost of project came from the MUNIES data.

f) project and cost came from the sewer referendum of 1977 .

Note--For capital expenditures such as the sewer project, the two fire stations (Stations $\# 5$ and \#6), and the community center, the town must authorize the total amount of money in one year which is required by the project. This could be taken care of through municipal bonds. The actual allocation of costs could be spread out for administrative reasons (as we have done), but a f1rm commitment is required from the various financial sources on projects of this callbre.

See Appendix $C$ at the end of this report which contains further information on projects and costs. 
PROPOSED CAPITAL IMFROVEMENT PROGRAM (1978-1993)

I. Proposed Capital Improvement Plan. July 1, 1978 to June 30, 1983

Project

Public Works

Equipmenta

Road Resurface

and drainage starting completion date date

$$
78-79
$$

83-84

$78-79$

$83-84$

80

estimated disbursements required during-in $000^{\prime}$ 's

Total 78-79 29-80 80-81 81-82 82-83

Cost

Public Bldg. Energy

Conservation

Program ${ }^{2}$

$79-80$

$81-82$

25

40

40

105

Brush Fire Truck ${ }^{a}$

78-79

78-79

12

$79-80$

12

83-84

50

50

$79-80$

$79-80$

$79-80$

25

6

New Pollce Care

$79-80$

$79-80$

81-82

81-82

$82-83$

$82-83$

Central and Feurer

Park Improvements ${ }^{4}$

78-79

$78-79$

9

$79-80 \quad 79-80$

16

16

Mini-bus

McGinn Park Tennis

Courts (resurface)

$80-81 \quad 80-81$

$80-81$

49

83-84

$81-82$

$\begin{array}{ll}a_{78-79} & 80-81 \\ 81-82 & 83-84\end{array}$

COLUMN TOTAIS

\begin{tabular}{llllll} 
& & 1670 & 1670 & 5000 \\
\hline 184 & 332 & 309 & 1916 & 1876 & 6468
\end{tabular}

Note--The total costs for the Public Works Equip.. Road resurface and drainage, Fire apparatus, and Sewer Project include the 83-84 costs. 
II. Proposed Capital Improvement PIan.

\begin{tabular}{|c|c|c|c|c|c|c|c|c|}
\hline Project & $\frac{\frac{\text { starting }}{\text { date }}}{}$ & $\frac{\text { completion }}{\text { date }}$ & $83-\frac{e s}{\frac{\text { re }}{84}}$ & $\frac{\text { imated }}{\text { uired }}$ & $\frac{\frac{\text { d disbu }}{\text { during }}}{\frac{85-86}{}}$ & $\begin{array}{l}\text { irsemen } \\
81 \text { On } \\
86-87 \\
\end{array}$ & $\begin{array}{l}\frac{n t s}{00^{\prime} s} \\
\underline{87-88}\end{array}$ & $\frac{\text { Total }}{\text { Cost }}$ \\
\hline $\begin{array}{l}\text { New Fire Station \# } \\
\frac{\text { at the Cranston-rt }}{102 \text { rotary }}\end{array}$ & $84-85$ & $85-86$ & & 52 & 52 & & & 104 \\
\hline $\begin{array}{l}\text { Replace Fire Stat1 } \\
\text { \#5 at North Quid- } \\
\text { nessett Rd. }\end{array}$ & $\frac{\text { Lon }}{86-87}$ & $87-88$ & & & & 52 & 52 & 104 \\
\hline New Police Car & $84-85$ & $84-85$ & & 6 & & & & 6 \\
\hline New Police Car ${ }^{e}$ & $85-86$ & $85-86$ & & & 6 & & & 6 \\
\hline New Folice Car & $86-87$ & $86-87$ & & & & 6 & & 6 \\
\hline $\begin{array}{l}\text { Davisville Play- } \\
\text { ground Improvement }\end{array}$ & $83-84$ & $84-85$ & 5 & 5 & & & & 10 \\
\hline$\frac{\text { Quidnessett }}{\text { Playground }}$ & $85-86$ & $85-86$ & & & 5 & & & 5 \\
\hline$\frac{\text { Camp Ave. Play- }}{\text { ground }}$ & $86-87$ & $86-87$ & & & & 5 & & 5 \\
\hline COLUMN TOTALS & & & 5 & 63 & 63 & 63 & 52 & 246 \\
\hline
\end{tabular}

III. Proposed Capital Improvement Plan. July 1, 1988 to June 30, 1993

\begin{tabular}{|c|c|c|c|c|c|c|c|c|}
\hline Project & $\frac{\text { starting }}{\text { date }}$ & $\frac{\text { completion }}{\text { date }}$ & $\underline{88-\frac{e s}{r e}}$ & $\frac{\frac{\text { imate }}{\text { uired }}}{89-90}$ & $\frac{\frac{d \text { disbi }}{\text { during }}}{20-91}$ & $\begin{array}{l}\text { urseme } \\
8-1 n c \\
21-92\end{array}$ & $\begin{array}{l}\frac{\text { ents }}{000^{\prime} s} \\
222-93\end{array}$ & $\frac{\text { Total }}{\text { Cost }}$ \\
\hline $\begin{array}{l}\text { Expansion of living } \\
\text { quarters at Fire } \\
\text { Station } \$ \text { t } 4 \text { in Sloam }\end{array}$ & d $88-89$ & $88-89$ & 35 & & & & & 35 \\
\hline New Pollce Car & $88-89$ & $88-89$ & 6 & & & & & 6 \\
\hline New Pollce Care & $89-90$ & $89-90$ & & 6 & & & & 6 \\
\hline New Police Care & $91-92$ & $91-92$ & & & & 6 & & 6 \\
\hline$\frac{\text { New Wickford Com- }}{\text { mun1ty Centerc }}$ & $89-90$ & $90-91$ & & 500 & 500 & & & 1000 \\
\hline Slocum Playsround & $92-93$ & $92-93$ & & & & & 5 & 5 \\
\hline COLUMN TOTALS & & & 41 & 506 & 500 & 6 & 5 & 1058 \\
\hline
\end{tabular}


How would the capital improvement program affect a prospective developer? As explained in Appendix A under the "vested approval" section, a developer will be credited with the corresponding number of points if a given capital improvement is scheduled for completion within one year of the date of application for a special permit. For example, a developer has a plan to construct a housing unit in the vicinity of the Cranston-Rt. 102 rotary and applies for the special permit in September, 1985. Since the development would be within two (2) miles of the proposed new fire station, at the rotary, and the fire station is scheduled to be completed by June 30 , 1986. the developer would recelve three (3) points. Chapter Four presents more detalled, hypothetical examples of the application of the methodology.

C. Energy Conservation and the Role of Local Government

The Town of North Kingstown, Rhode Island, as part of the larger regional setting, has had to deal with the rising costs and fluctuating supplies of traditional sources of energy. The region has experienced financial pressures, planning uncertainties and performance limitations. As a result, there has been widespread recognition of an "energy problem" and perception of a need for action to assure a continuous and adequate supply of energy. Energy conservation should be one action of local concern. Capital improvement planning and land use planning/zoning are two common functions of local government which offer great potential for improving local energy efficiency. 
The capital improvement decisions of local governments offer opportunities for conserving energy in government as well as in other local uses. The location and type of sewer and water facilities, streets and street lighting, parks, and government bulldings are important determinants of the energy required for long-term facility operations and for the accompanying commercial, industrial, and residential development. When town officials decide to pave or widen a street, build a new school, improve the city bus system, or extend services to a previously unsupplied area, they are making decisions that influence where houses and factorles will be built and how people will travel around the c1ty. These are factors that are key determinants in the level and efficiency of community energy use. Taking the energy consequences of capital improvements into account can ultimately reduce the energy needed for city services, for automobile travel, and for heating and cooling of buildings. 4

The City of Portland, Oregon has spent considerable attention on 1dentifying how local government can consider energy in capital decisions. The major "thrust" behind their project was to design a simplified procedure for evaluating the "Induced" energy impact of a capital improvement project. As a result, the city is considering changes in its capital improvements planning process to add community impact evaluations to its decision factors. Planners in Portland have divided the city into five "energy zones" based on the availability of water and sewer services and proximity to public 
transit, shopping and jobs. City bureaus, in presenting proposed capital improvements, must indicate the "energy zone" of each project and of its total service area and must justify projects with indications of high energy inefficiency. Thus, city decision makers can weigh the potential impact on community energy use against other priorities for capital investment. 5

Zoning and land use planning is similar to capital improvements programming in its impact on community development patterns. For example, our controlled growth plan for North Kingstown directs the "where" and "when" of development in order to promote energy conservation by discouraging fringe development in areas with high energy costs for services and transportation. It must be pointed out that the plan would result in even greater energy savings if commercial and industrial developments were also subject to the permit process, thereby ensuring contiguous growth.

Zoning can encourage such energy-saving land development as cluster and multi-family housing rather than scattered single-family housing. In fact, under the point system set up by the controlled growth plan, points are awarded for planned unit developments and clustered housing which incorporate the stated goal of energy conservation and design features. It has been well documented ${ }^{6}$ that residential space heating needs can be reduced by up to $60 \%$ by bullding homes which have more common walls and floors, such as townhouses, duplexes, semidetached houses, and apartments. This lowers space-heating 
requirements by reducing the amount of exposed surface which loses heat. Therefore, land use zoning and policy decisions can reduce residential energy consumption by:

1) encouraging the construction of multi-family housing along major transit streets, near major employment areas and near shopping centers;

2) encouraging construction of more high-quality small homes, condominiums, and apartments; and.

3) encouraging the conversion of large, single-family homes to include a rental unit.?

The Town of North Kingstown should zone more land for multi-family residential construction. An examination of the Community Development Plan of North Kingstown shows a very small percentage of this land-use category comprising total residential use as opposed to single-family residential use.

\section{TABLE IV}

\section{SURVEY OF LAND USE, NORTH KINGSTOWN 8}

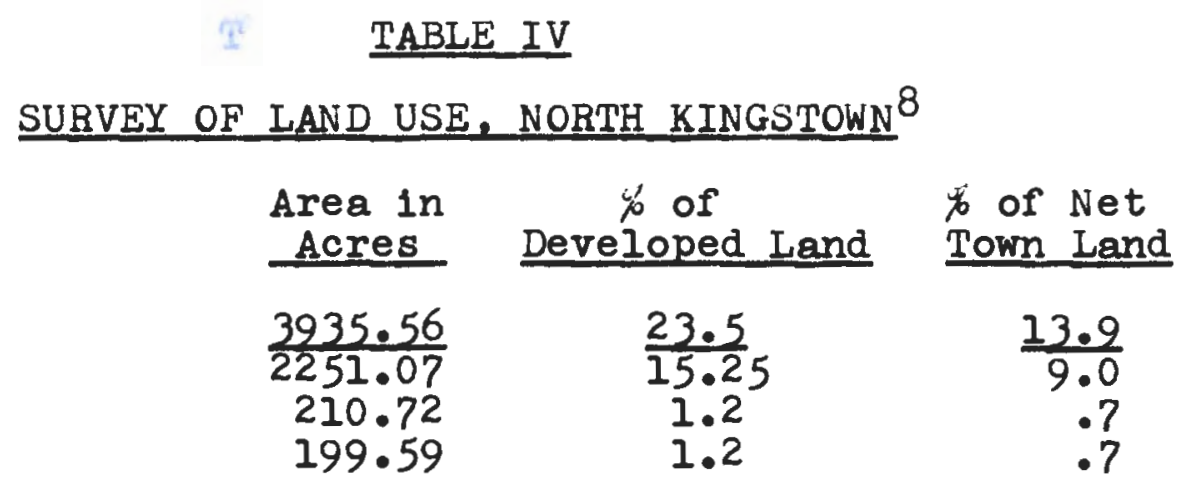

Residential Single-family Multi-family

Two-f amily

As a result, developers would be encouraged to construct higher density units without having to go through costly, time consuming zone change procedures.

Taking Advantage of the Natural Environment

Another way to increase the thermal efficiency of buildings is to take advantage of the natural environment to shelter buildings from extreme variations in temperature. For example, strategically located plants can direct breezes into buildings In warm seasons and also act as wind breaks in cold seasons. 
F18. II

Confferous trees

on the north*
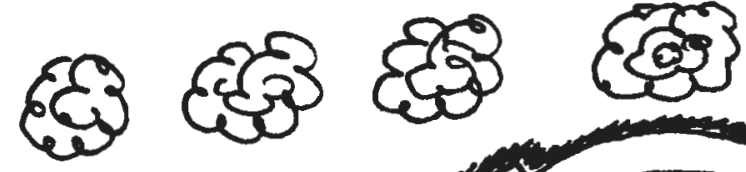

north

Incorporation of site

objectives
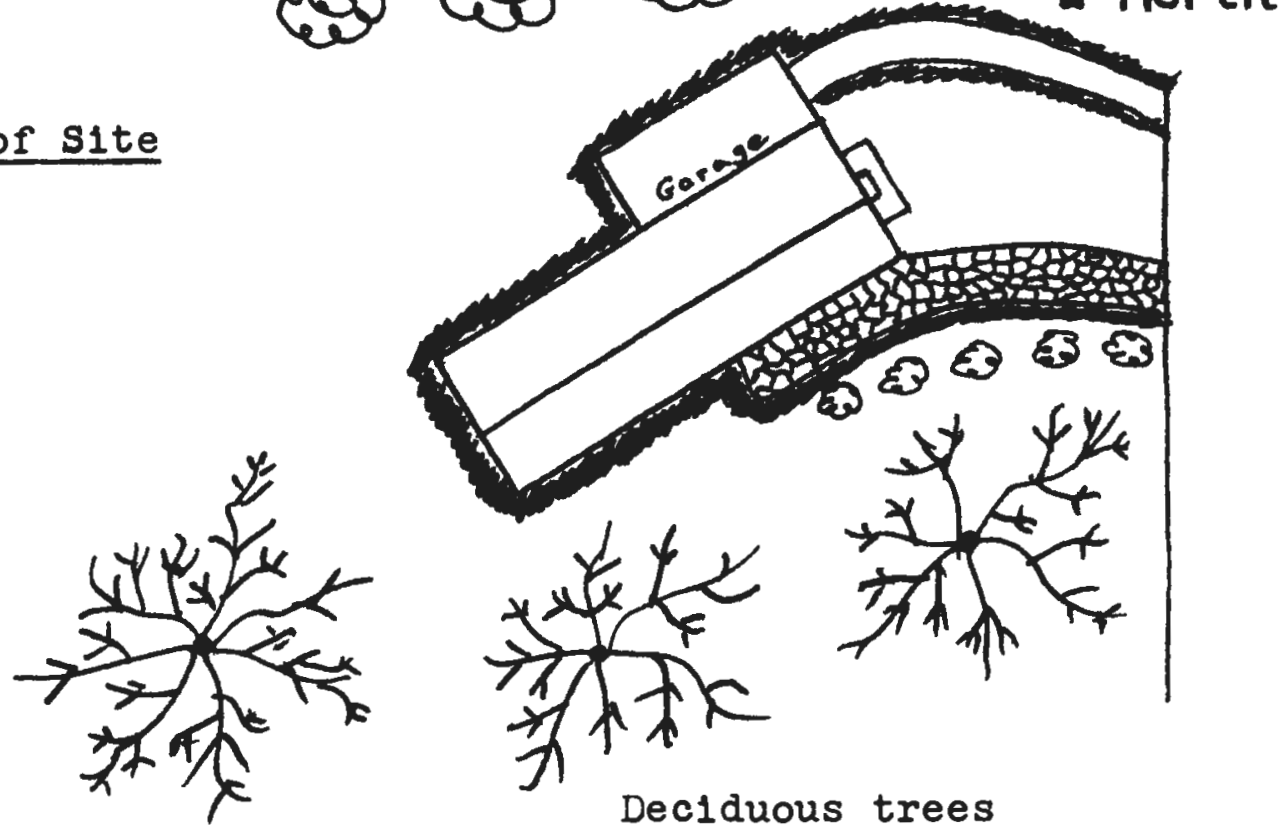

Dec1duous trees on the south**

Notes: *-this classification refers to vegetation which maintains its cover throughout the year (for eg. evergreens). These trees w1ll keep the harsh northern winds away in the winter: **-this classification refers to vegetation which maintains its cover seasonally (for eg. maple, oak trees). These trees will shade the building during the summer and allow the strong south sun to penetrate in the winter.

The building is oriented $45^{\circ}$ to the prevalilng wind (north). The non-heated bullding space is on the windward side. The bullding has a maximum pitched roof area (Cape Cod "Salt Box") and minimum wall areas on the windward side of the building.

The use of vines or other plant materlal on sunny brick, stone or concrete walls along with the planting of grass against buildings will help to maintain a cool environment during the summer months.

Special permit decisions, made under the controlled growth system, can promote the goal of energy efficiency with 
permit preferences granted for sites which take advantage of the natural environment, along with energy efficient circulation and parking patterns, and use of innovative energy sources such as solar energy. Circulation and Parking 9

The careful design of circulation systems and parking facilities can significantly reduce energy use. Streets are important in terms of energy conservation because a little over half of the energy we consume is used to power cars. Thus. everything we gain from good bulldings can be lost in poor street and auto design. The energy investment in streets for construction and maintenance is only one part of the energy cost. Construction energy includes: heavy equipment operation; the asphalt used in streets: the energy used to make cement for sidewalks, etc. Maintenance costs include street sweeping. repairs, and patching. In addition, wide streets increase sprawl, and the decreasing density fosters more dependence on the car which is both energy and money intensive. Streets also ralse alr temperature in the summer and create sometimes difficult to manage storm water run-off in the winter.

There are four ways to get around in North Kingstown-walking. biking. limited use of public transit, and the private automobile. If, and when, a conflict occurs between motorized and non-motorized systems, the non-motorized system should be favored.

1) Walking

Walking is a means for short distance travel. This 
mode of transport ought to be made as convenient as possible. Sidewalks should be supplemented with intra-block easements (F18. II), and easements through cul-de-sacs which could be used by bikes and pedestrians (Fig. III).

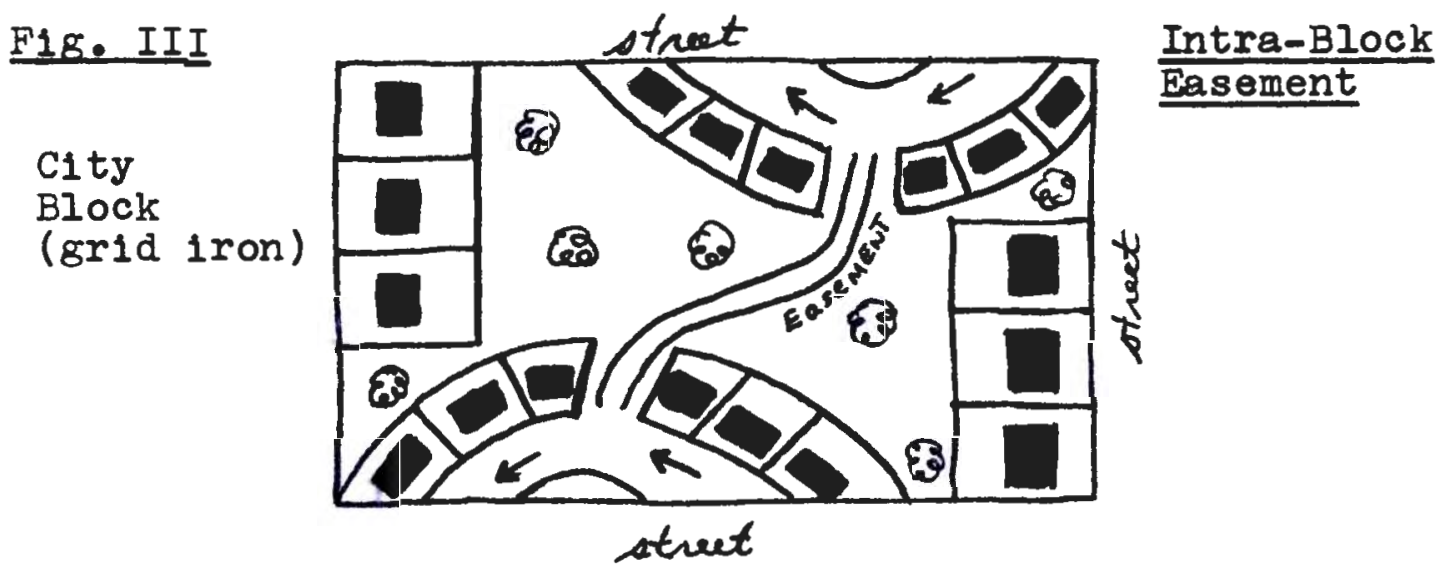

Fig. IV Easement through Cul-de-sacs

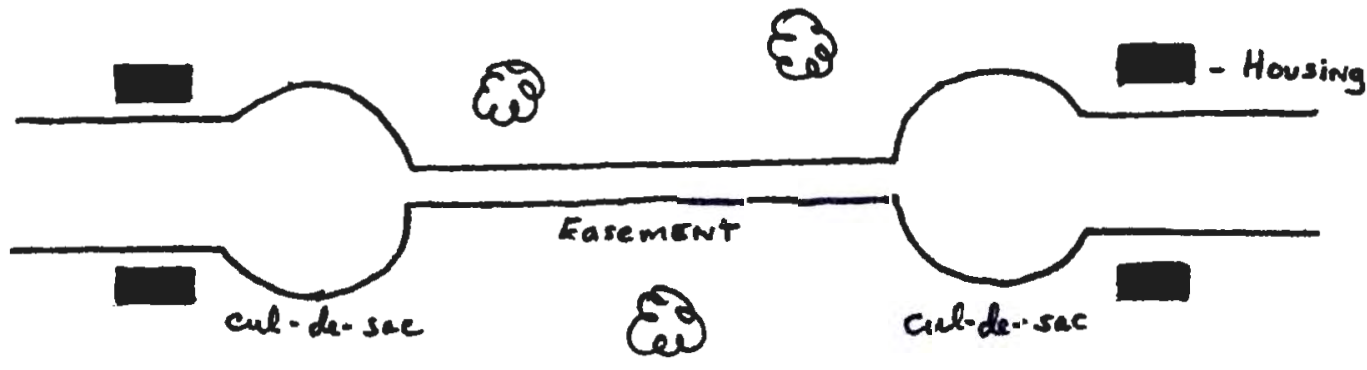

\section{2) Bicycles}

Bicycles should be considered a favored means of transportation. They are clean, healthy, efficient, quiet, durable, aesthetic, and inexpensive to buy and operate. In addition, bicycles are space efficient and avallable to more people than most transit modes. It has been stated that they provide excellent transportation for distances of under 12 miles. There are some important considerations in planning for bicycles that 
w1ll affect the design of neighborhoods:

1) bicycles need the most direct route possible from point A to point $B$. The street system should be supplemented with a system of paths and easements;

2) protection from winter north winds and summer heat should be provided to keep the bicyclist comfortable. This can be provided by shade and wind break plantings as well as by building masses;

3) the bike system for each neighborhood should be easy to follow, direct, and convenient for internelghborhood travel as well as a functioning part of the c1ty network. 10

\section{3) Public Transport}

As North Kingstown grows larger, buses or other forms of public transport w1ll become more 1mportant. To encourage the use of public transportation, the most direct possible system of pedestrian access must lead to bus routes.

\section{4) Auto Transportation}

The auto circulation system has been overdeveloped in our country today. This encourages people to make use of this very inefficient transportation system and discourages the biker and pedestrian.

It is important that the width of streets be kept to a minimum, yet still maintain safe, efficient movement of automobile traffic along with bicycles on neighborhood streets. In situations where the volume of traffic is low, a 241 wide street with parking in bays adequate to meet ordinary needs rather than parking at the curb, would be more economical. This would provide safe low speed auto access with adequate space for bicycle traffic. Streets 241 wide allow enough space for backing out of bays or driveways. Large trees closely spaced along the local street would provide shade 
and comfort during the summer months for pedestrians and bicyclists.

F1g. V Street with Farking Bays

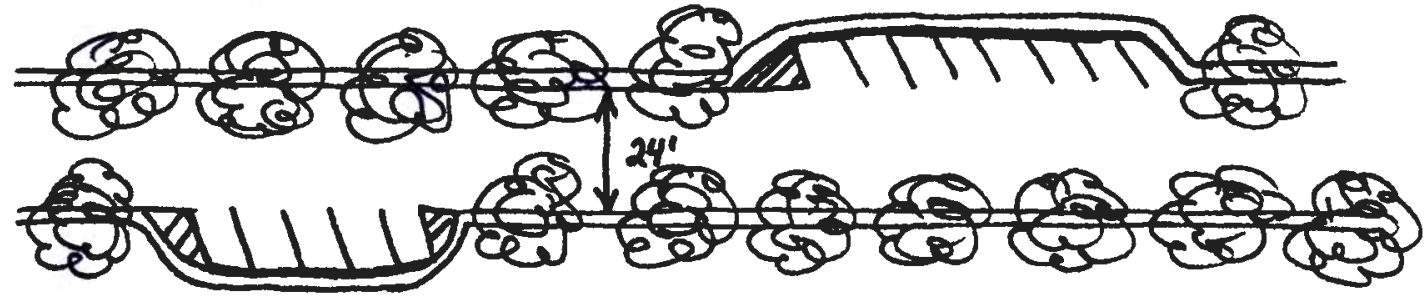

In general, developers should be encouraged to find solutions to automobile, circulation, and parking problems that devote as little space as possible to the car. The area saved should be utilized as parks, green belts, pedestrian and bike paths, and for private use. S1te Design \& The Efficient Use of the Sun

All sites should be encouraged to maximize the benefits of good solar orientation. To this end, applicants wishing to secure points for energy elements under the controlled growth system should submit drawings which take into consideration the following elements used by the City of Davis, California.

An applicant must:

A. Show how the proposed design w1ll encourage good solar orientation. (1.e.. one planning for good solar orientation must look at street layout and size; lot size and shape; the size, shape and helght of the bulldings and regetation; and also pay particular attention to the overall plan and setbacks.) Th1s proposal must show how the future installation of solar collection devices is facilitated.

B. Establish envelope zoning by submission of a map which describes in 3 dimensions the space which can be occupied by buildings and/or evergreen vegetation. (Note: deciduous regetation whose branching pattern intercepts more than $20 \%$ of the 
direct solar radiation from November 15 to March 15 is considered to be evergreen vegetation for the purposes of this paragraph.) The envelope shape and sizing shall be designed so that shading of adjacent properties or buildings is minimized for 12 noon on December 21 . The submitted map shall show the shadows cast at 12 noon on December 21 by the envelope. The submitted map shall become a permanent agreement limiting building height on the property. 11

Some may argue that solar energy is not practically feasible, on a large scale, here in New England today. The point may be well taken, but, we have got to plan for the long run when such technology is more advanced and cheaper for the average homeowner. The development of sites, today, must be at least ready to be equipped in the future with solar devices and other alternative energy sources. If this is not done, we have lost just that much more time, money, natural resources, and energy.

Our growth control ordinance incorporates the broad goal of energy conservation. Through the accumulation of development points, it encourages residential developers to make efficient use of energy in terms of site and building design in order to foster the long term stability of the site and adjacent lands. The specific guidelines that developers and administrators can follow is found within the ordinance 1tself in Appendix A or in Figure VI, page $56 \mathrm{~A}$. D. Low and Moderate Income Housing

There is little doubt that any discussion of low and moderate income housing will be highly controversial. Many communities are simply against such housing for a variety of reasons. Some of these reasons are based on racial prejudice, 
Fig. VI

\section{Energy criteria}

To encourage residential development to be efficient in terms of site design, bullding layout and orientation, and landscaping in order to promote maximum potential for energy conservation and so that the longterm stability of the site and adjacent lands are secure and the overall communty value enhanced. (Maximum thirty (30) points.)

4 pts. - A. Efficiency of Site Design (Maximum 8 pts.)

4 pts. - For planned unit developments (PUD) and clustered housing which incorporate the stated goal of energy conservation and design features.

4 pts. - Maximum use of conservation measures by incorporating within the site and building design improved insulation, and the use of solar or other non-fossil fuel source.

0 pts. - Does not consider the above.

2 pts. - B. Wind Protection for Developments

2 pts. - Most effective shelterbelts used and located where most of the development is within 10-20 times the average helght of the shelterbelt.

0 pts. - Does not consider the above.

2 pts. - C. Wind Protection for Individual Dwellings (Maximum 10 pts.)

2 pts. - Windscreen used for a dwelling with optimal distance from dwelling (not further than 5 times helght or closer than $\frac{1}{2}$ times spread.)

2 pts. - Dwelling orlented between $45^{\circ}$ and $90^{\circ}$ prevalling wind.

2 pts. - Nonheated residential bullding spaces on windward.

2 pts. - Maximum pitched roof areas and minimum wall areas on windward side of dwelling.

2 pts. - Optimal wind protection to three sides of dwelling.

0 pts. - Does not consider the above.

2 pts. - D. Shading (Maximum 8 pts.)

2 pts. - Outside shading devices used to shade major window areas from $10 \mathrm{~A} . \mathrm{M}$. to $5 \mathrm{P} . \mathrm{M}$. 
2 pts. - Dec1duous trees used for shading placed in optimal location for summer shade.

2 pts. - Vines used on sunny brick, stone, or concrete walls.

2 pts. - Grass or other plant materials used against dwellings rather than paring.

2 pts: - E. Circulation and Parking

2 pts. - The street system that is adjacent to and serves the property, whether constructed by the developer or not: (1) discourages high speeds especially in situations where there is no physical separation (such as a wall) between the roadway and the development; (2) minimizes pedestrian-vehicular conflicts; and (3) provides for alternative modes of transportation by providing on-site facilities for and external linkages with other modes of transportation where applicable, 1.e., bus shelters, bike paths, functional pedestrian circulation system. 
economic status (not wanting to live near lower income groups). financial justifications (belief that low and moderate income housing will bring in little tax revenue and therefore will burden present services), etc., etc.

Towns and clties in R.I.. like many in the United States, could be included in the above description. Rhode Island is also a state with a strong home rule tradition. This has enabled the towns and cities to control their own housing policies and zoning ordinances, among other things. As Statewide Planning has pointed out in their Problems of $R . I$. Land Use Laws publication, only eleven municipalities have public housing for non-elderly families. However, many communities have significant numbers of lower income households in need of decent, affordable housing. In addition, housing costs are rising faster than family income, pricing more and more people out of the single-family market. ${ }^{12}$ simply stated, there is a shortage of "up to standards" low and moderate income housing for lower income people.

Two laws have created agencles that are empowered to help alleviate low and moderate income housing problems in $R . I .$. the Department of Community Affairs (DCA). (which of course has many other functions as well) and the Rhode Island Housing and Mortgage Finance Corporation. Unfortunately neither agency has had a very significant impact on providing lower income housing in the state (although probably due, in part, to c1rcumstances beyond their control such as strong home rule). 
DCA is currently involved in administering the Housing and Urban Development (HUD) Section elght (8) rental assistance program. However, the tenant must find existing housing, which is certainly no easy task. The programs sponsored by the Rhode Island Housing and Mortgage Finance Corporation have mainly catered to elderly housing and not low and moderate income family housing. This is an important distinction. In fact, most of the low and moderate income housing in R.I. is for elderly.

According to the Urban Design Group. Inc., about $67 \%$ of the total households in North Kingstown in 1970, would have qualified for FHA subsidized housing. 13 since 1970 the town has concentrated most of 1 ts efforts on supplying needed low and moderate income elderly units. As of 1978. 1t could be generally stated that the town had fulfilled its elderly housing needs. However, the most recent Housing Assistance Plan for North Kingstown (1977) shows that up to April. 1979. 868 non-elderly lower income households will need some sort of housing assistance. This assistance might include the construction of new rental units, the rehabilitation of existing rental units, rental assistance, or rehabilitation assistance to homeowners or prospective homeowners.

How would the existence of a growth control plan affect the need for low and moderate income housing in North Kingstown? In the wake of the Ramapo and Petaluma decisions, antiexclusionists have argued that growth controls make it harder 
for lower income groups to find housing. They reason that by holding up development, the cholces for low and moderate income people are even further reduced. Others have argued that growth controls actually raise housing prices.

In response to the first criticism, we maintain that competent and sensitive housing policies are needed to ensure against further reducing housing choices for low and moderate income people. To help combat such an occurrence we have, as stated, provided in the point system an incentive for developers to consider bullding lower income housing. As for the second point. it is difficult to ascertain whether a given growth control actually raises housing prices or whether the market continues to sky-rocket on its own. Perhaps the best alternative, as we suggested in the "Remedies" section of this chapter, is to attempt to study the effect of the growth control on housing prices both in and outside the locality after the growth control has been in operation for a number of years. Then, as Ellickson explains, the best course of action can be taken by all concerned parties.

In relation to the low and moderate income housing section of the point system in Appendix A, we have set limits on the number of low and moderate income units. In other words, once the town has satisfied its need for low and moderate income units for each five year period of the fifteen year plan, it w1ll no longer award developers incentive points for such housing.

The following table shows the low and moderate income housing unit limits for each of the three five year periods. 


\section{TABLE V}

LOW AND MODERATE INCOME HOUSING UNIT LIMITS FOR THE THREE FIVE YEAR PERIODS 1979-1983, 1984-1988, and 1989-1993

type of development

low and moderate income

elderly

non-elderly moderate income

non-elderly low income

type of development

elderly

moderate

low

type of development

elderly

moderate

low

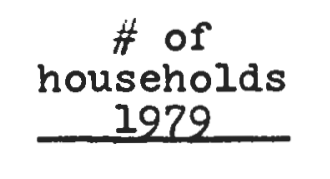

112

450

450

1984

147

591

591

$\underline{1989}$

179

722

722

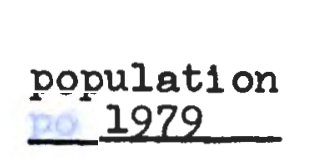

housing unit $11 \mathrm{mit}$
$1929-1983$

26

103

103

$\underline{1984-1988}$

26

103

103

$1989-1993$

21

84

84

(See Appendix $D$ at the end of this report for an explanation of methods used.)

For example, the above table means that in the period between 1979-1983, a developer planning to build non-elderly low income units will no longer recelve any incentive or bonus points once special permits have been issued to construct 103 or more units. This will allow North kingstown to meet its low and moderate income housing needs but at the same time help prevent the town from becoming over-run with such housing. The above table considers housing needs for the town. it does not consider state or regional needs. Many exclusionary zoning cases have made it emphatically clear that "the general welfare" does not stop at the town's boundary. ${ }^{14}$ Town officials 
61

should be aware that "fair share" housing refers to regional as well as municipal low and moderate income housing needs.

As it has been suggested in the past, the Town would benefit from the creation of a Local Housing Authority. Such a department would be the most capable of deciding the low and moderate income housing unit limits. As we mentioned earlier, it is highly recommended that town officials or the Local Housing Authority update the five year limits each year. In summary, the criteria for the "Low and Moderate Income Housing" category are based upon the sub-categories of low and moderate income elderly housing, non-elderly moderate income housing, and non-elderly low income housing. Developers will receive one point for each low or moderate income unit they plan to construct. However, developers can only recelve a maximum of twenty (20) points regardless of how many units they actually plan to build. In the event that low and moderate income unit limits have been satisfied, no incentive points will be awarded. Note that there is no quota on the number of low and moderate income units that can be built in the Town. Yet, there will be a "cut-off" point or limit at which time developers will no longer recelve points. (See Appendix A or Figure VII, p. 61 A for the lower income housing criteria.) E. Remedies

If North Kingstown were to officially adopt the point system as part of their zoning ordinance, there are a number 
F1s. VII

Low and Moderate Income Housing criteria

To provide needed low and moderate income housing. (Maximum 20 pts.)

Type of Development

Points per/unit able points

elderly low and moderate income

1

20

moderate income (non-elderly)

1

20

low income (non-elderly)

1

20 
of legal questions that could be raised. Appendix B, Legal Considerations. will deal with a number of these issues. This brief section w1Il only focus on the issue of "just compensation."

The fifth amendment of the United States Constitution states that "no private property shall be taken for public use. without just compensation." Most town charters contain a similar clause, as does the charter of North Kingstown. Since the point system allows for developers to include pubI1c facilities or capital improvements (in order to secure more points), the town may be liable to compensate the developer.

When a developer pays a fee to the town in return for public services, he or she is paying what is known as a "development charge." Ellickson has argued that the injury suffered by a landowner, developer, or consumer, if indeed an injury has taken place, is best remedied by the awarding of damages (cash). He explains that the usual court procedure calls for the developer to seek an injunction against enforcement of the growth control either whole or in part or to deny any relief whatsoever. A far more equitable and agreeable (to all parties) solution, he maintains, is to award damages. The remainder of this section will prescribe some general rules that might govern growth control and associated development charges disputes. 15

Ellickson has suggested that the legal doctrine developed 
to decide growth control questions be designed to promote three principle goals: efficiency, horizontal equity, and vertical equity. Efficlency dictates that new housing developments that are not cost-effective should not occur and those that are cost-effective should occur. Horizontal equity requires that governments treat persons alike. Vertical equity is a term used in public finance literature to describe the falmess of the distribution of wealth (services) among different income groups.

Bullding, in part, from the above premise, Ellickson argues that the Michelman test is an accepted method of deciding whether a suburb's growth control program is fair and need not compensate. The Michelman test consists of two axiom. A suburb's growth control program is considered fair and need not compensate if it can prove that its policy is (1) efficient and (2) therefore within the long term best interests of all parties concerned. On the other hand, Ellickson warns that all persons must be treated allke. Furthermore, all landowners, homeowners, or consumers, should recelve approximately the same "net benefits" over time. A landowner's "net benefits" from a municipal service may be defined as (1) the municipality's expenditures in servicing h1s land. less (2) the development charges collected from that landowner for that service.

An 1llustration is in order. If a homeowner in a remote part of town wanted the water system extended to serve him. 1t would be the town's duty to award a damages payment 
to the owner. This would be a sum (cash payment) equal to the town's average per dwelling unit expenditure on water service. Alternatively, the town could provide water service to the homeowner as long as the homeowner pald for all service costs exceeding average service costs. Courts have usually either ruled that towns extend the service or deny that the service must be extended. Ellickson's solution seems far more equitable.

Let us continue w1th the above hypothetical 1llustration in more detall. Jones owns an unimproved lot in a remote area of North K1ngstown. Suppose 1t would cost the town $\$ 5,000$ to extend a water Iine to Jones' lot. This $\$ 5.000$ would be much greater than the historic $\$ 1,000$ average cost of providing water lines to other dwelling units in North Kingstown. How much should the town be entltled to charge Jones for water service? Assuming that the town finances water lines from "general revenue," Jones would be entitled to $\$ 1,000$ in net water benefits $(\$ 5,000-\$ 4,000=\$ 1,000)$. In other words. North Kingstown could charge Jones $\$ 4,000$ for the water connection fee. The fact that North Kingstown had financed water service with general revenue is a key point. If North Kingstown financed its water service through a "special revenue" then the town could legally charge Jones the full $\$ 5,000$. This is based on the reasoning that all homeowners were or would be charged approximately the same fee. In summary, Ellickson claims that there are four important questions of growth control law: ${ }^{16}$ 
(1) When should landowners be absolutely privileged to proceed with development? Almost never. The municipality must be entitied to implement efficient growth control programs.

(2) What kinds of development should a municipality be able to stop without paying compensation to landowners? When a government proh1b1ts sub-normal (below average) land uses, a landowner should be required to prove that prohibition is grossly inefficient in order to recover for any resulting diminution in the value of his land. Most growth controls restrict land-uses that are not subnormal. When a suburban restriction that dictates abovenormal landowner conduct that substantially reduces the value of a person's land, that person should recelve compensation unless the suburb can affirmatively prove that its restriction is both fair to the landowner and efficient.

(3) What development charges should a local government be entitled to impose? Special charges designed to raise general revenue attached to new housing construction are often horizontally unfair because they treat old residents and new, largely politically unrepresented groups differently. Therefore, new development charges only imposed on new construction should be prohibited. However, special charges for a specific service are satisfactory if both old residents and new residents receive the same net benefits over time.

(4) When a suburb enacts a restriction that is enforceable but for which it is liable in damages, how much compensation should landowners and housing consumers recelve? The measure of damages differs for the two groups. A landowner's compensation is determined by how much the restriction reduces the market value of his land. In appraising what the land valuation would be if there were no restriction, one should take into account the valid development charges and uncompensated use restrictions that the suburb might have enacted; otherwise the landowner would recelve compensation that would make him better of $f$ than his neighbors. Consumers should be entitied to recover (usually by class action) any damages they have suffered as a result of a housing price increase attributable to a suburb's policies. But damages should not be granted to consumers whenever the suburb demonstrates that 1 ts growth controls are not only efficient but also fair to consumers.

It is obvious that there is no simple rule for deciding disputes. Each case can be different from the previous ones. The above general rules are not laws. Yet, we feel that 
Ellickson has done an excellent job of addressing possible solutions to such problems and his suggestions should serve as a useful guide. 
1. Kirk W1ckersham. Jr.. AIF, "A Better Way to Regulate Development." in Practicing Planner. September, 1977. p. $14-16$.

2. This standard of $65 \%$ comes from the Ramapo. N.Y.. Zoning Amendment Conditioning Development Permits on Adequate Public Fac1lities - 46-13.1. There, developers were required to secure at least fifteen (15) development points out of a possible twenty-three (23) development points. 15 divided by $23=65 \%$ (rounded off).

3. We would like to express our thanks to Mr. Anthony Al01s10. our friend and fellow planning student, for allowing us to use some of the data he gathered for the MUNIES study.

4. Draft, Capacity-Bullding/Local Government Approaches to Energy Conservation. prepared for: Office of Policy Development and Research. Department of Housing and Urban Development, (1977), see page 9.

5. Draft, Volume 6: Portland Energy Conservation Demonstration Project Overview. by Donald $F$. Mazziotti and Marion L. Hemphill, for Mayor Ne1l Goldschmidt; Office of Pollcy Development and Research. U.S. Department of Housing and Urban Development, Contract $\mathrm{H}-2300$, June 1977, see page 71.

6. Volume 3B: Portland Energy Conservation Demonstration Project--Transportation and Land Use Conservation Choices. by Skidmore, Owings, and Merrili for the City of Portland, Oregon: Office of Policy Development and Research. U.S. Department of Housing and Urban Development, Contract $\mathrm{H}-2300$, June 1977, see page 18.

7. Volume 3B: Transportation and Land Use Conservation Cholces, see pages 26-31.

8. Community Development Plan. Town of North Kingstown. Rhode Island. September 1972; prepared by the North Kingstown Planning Department in conjunction with the North Kingstown Planning Commission: see page 50-Table 8. Survey of Current Land Use.

9. See: A Strategy for Energy Conservation and Solar Ut1l1zation ordinance for the City of Davis, California. by Living Systems, Winters, California, 1974; and, C1ty of Indio, California, Planning For Energy Conservation, prepared by: Living Systems, Winters, California, and C1ty of Indio Department of Planning and Development for Department of Housing and Urban Development (1977). 
10. See: Dav1s, California Ordinance, p. 30 .

11. Ibid., p. 37 .

12. Rhode Island Statewide Planning. Problems of Rhode Island Land Use Laws, March 1977. p. 7.

13. The Urban Design Group, Inc., North Kingstown Housing Element, 1975, prepared for the North Kingstown Planning Dept.. p. 20.

14. See: Southern Burlington County NAACP v. Township of Mount Laurel. 1975. New Jersey Supreme Court. Also see 0akwood at Madison, Inc., v. Township of Madison. 1971. New Jersey superior ct.

15. This discussion is based on the article by Robert $C$. Ellickson, "Suburban Growth Controls: An Economic and Legal Analysis," The Yale Law Joumal. volume 86 no. 3. January. 1977.

16. Ib1d.. p. 468 and 469. 
CHAPTER FOUR

\section{APPLICATION OF METHODOLOGY}

The purpose of this chapter is to 1llustrate to town administrators how the growth control methodology (point system) would affect a prospective developer. In other words, this chapter should exemplify how the methodology would be applied and how it would work.

Another relevant aspect of this section relates to the Importance of the capital improvement program. Throughout. we have argued that development should occur only after the services are avallable to support 1t. The more services avallable to a given developer, the higher the point total he or she will accumulate. And the greater the number of points totaled, the more likely the developer will receive the special permit.

The following fold-out map shows the location of existing services and future services, as depticted in the proposed capital improvement program (the map also shows the location of any future state plans). In addition, the map shows the location of two proposed hypothetical developments. (See next page )

To demonstrate how the methodology would be applied to a development, we created, as mentioned, two hypothetical examples (see below). Example I concerns a detached, single 
NORTH KINGSTOWN EXISTING AND

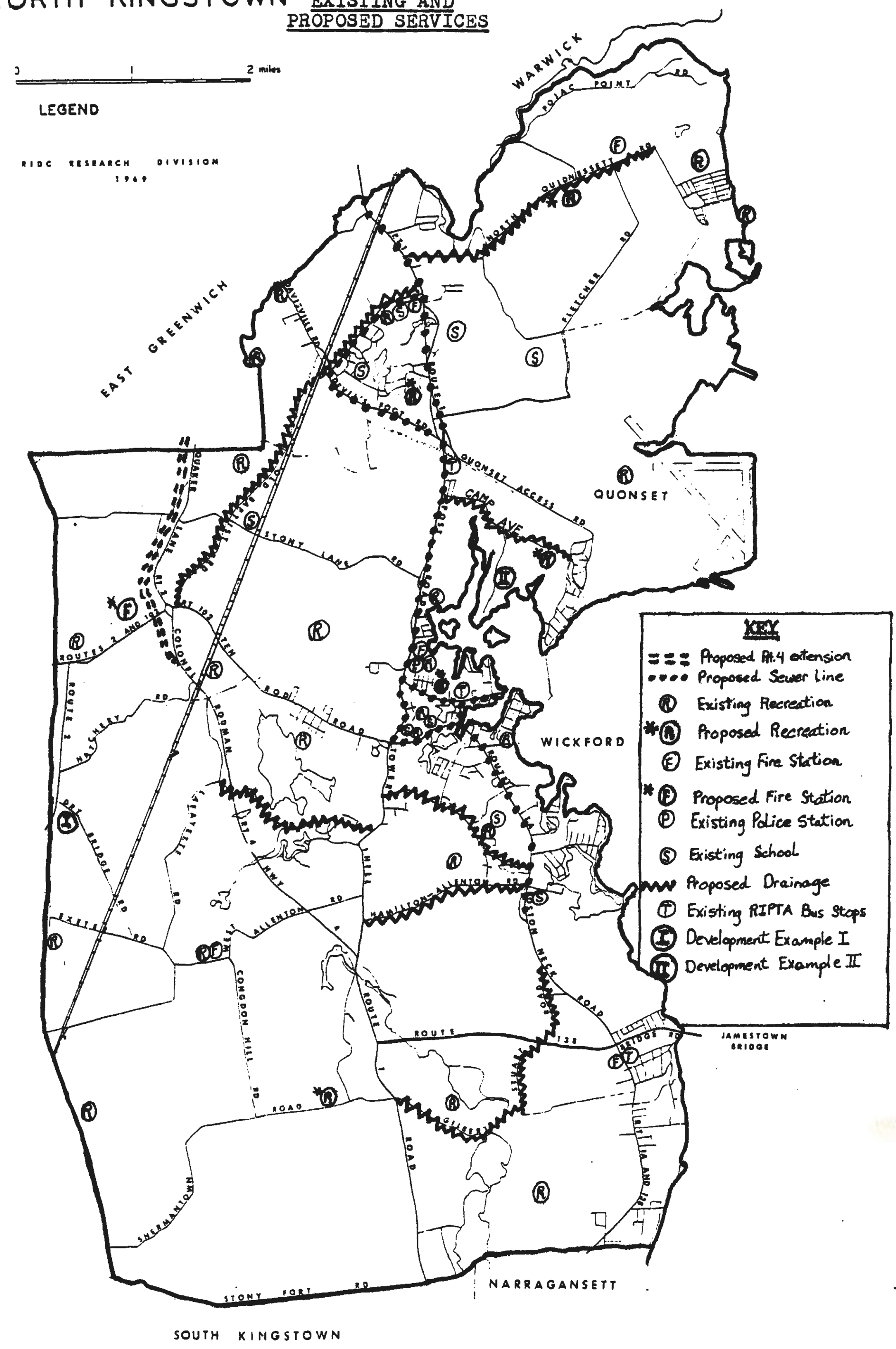


71

family dwelling. Example II consists of a somewhat large scale planned village district development. In choosing hypotheticals we attempted to pick realistic but rather contrasting examples within different areas of the town.

Before studying the two examples, the reader should note that measurements made to determine distances (to compute correct point totals) were taken from a large scale map (where $35 / 16$ inches = one (I) mile). The large scale map shows the same detall as the small fold-out map. Measurements were computed with a ruler and distances between points were measured along the shortest street routes. For a further clarification of measurements see Appendix A.

\section{EXAMPLE ONE}

Description of development

Mr. Harold J. Sm1th plans to construct a detached, single family dwelling unit. Location of development

Mr. Sm1th's development would be located on the west side of Dry Bridge Road, which runs of $f$ of Route 2, South County Trall. The development would be $1 / 5$ of a mlle from the corner of Dry Bridge Road and Rt. 2, w1thin plat 79, lot 2 which is zoned village residential.

Date of Application

September 1, 1988.

Sketch of development

See next page. (note--except for Mr. Sm1th's proposed development the sketch was taken directly from the Plat Maps of North Kingstown. 
F1g. VIII

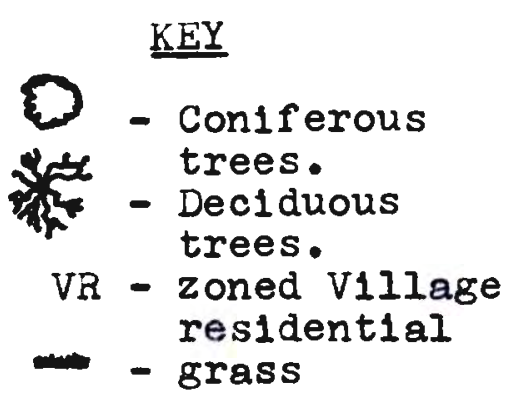

Harold J. Smith's

single family

housing development
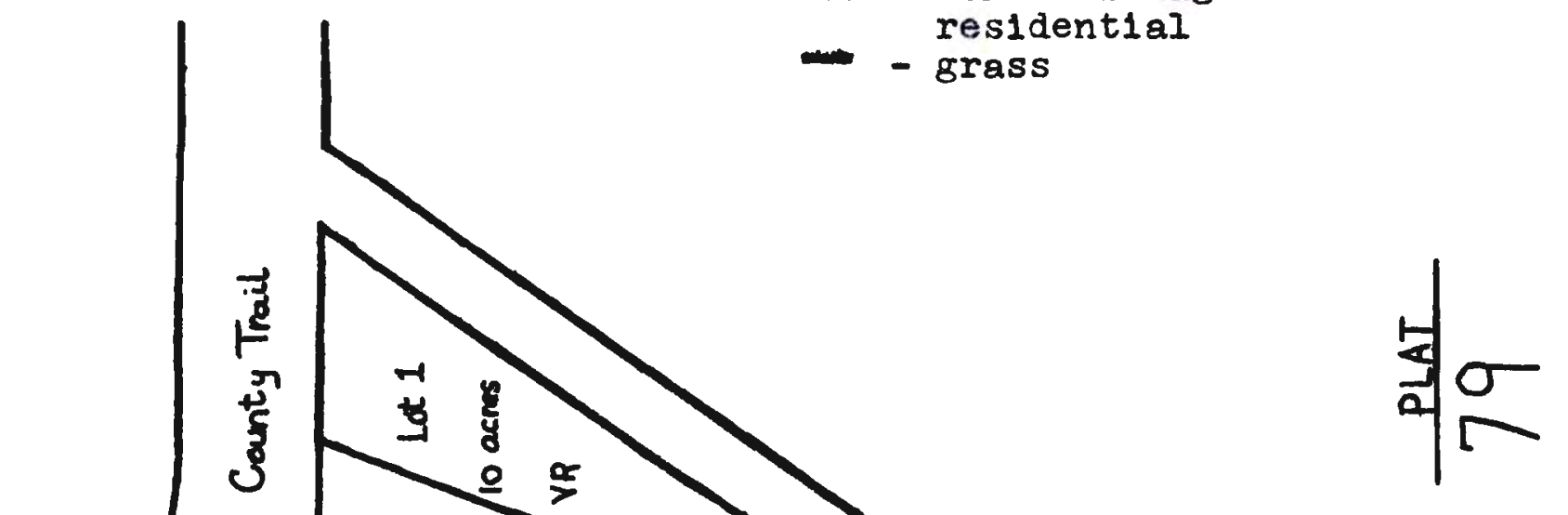
SCORE SHEET FOR SPECIAL PERMIT

(based on point system)

Name: Mr. Harold J. Smith

Location: Dry Bridge Rd.. 1/5 of a mile from Rt. 2, South County Trail

Date of Application: September 1. 1988

I. Public Facilities (Maximum 50 points)

pts.

A. State, County, or Town Major Secondary or Collector Roads

Direct access to Collector Rd.. Dry Bridge Rd.

B. Improved Public Fark or Recreation Facility including Public School Site

Further than one (I) mile from any recreation sites. No points.

C. Fire Protection

Within three (3) miles of elther new station \#6 at Cranston rotary or Slocum station \#4.

D. Water Distribution

Existing water mains and water system meet town standards for water service and fire protection. ${ }^{1}$

E. Sewers

Mr. Smith will install a state approved septic system. 
F. So11 Constraints

slight. 2

G. Police Protection

Development can be served by the existing personnel and facilities, and is within the existing service routes.

H. Flood Control

Development is not in the flood plain. ${ }^{3}$

I. School Capacity

Development is within five (5) miles of either Stony Lane Elementary School or W1 ckford Jr. High School and development will not exceed capacity limits.

J. Storm Drainage

Mr. Smith will provide the necessary drainage improvements to carry runoff generated by the development.

K. Public Transportation

Existing bus service exceeds $\frac{1}{2}$ mile from the development. No points. 
II. Energy Elements (Maximum 30 points)

pts.

A. Efficlency of Site Design

For planned unit developments (PUD) and clustered housing which.... Not applicable.

Maximum use of conservation measures by incorporating within the site and bullding design improved insulation, and the use of a woodburning stove, a non-fossil fuel.

B. Wind Protection For Developments

Not applicable.

C. Wind Protection For Individual Dwellings

Windscreen used for the dwelling with optimal distance from dwelling not further than five times height or closer than $\frac{1}{2}$ times spread.

Dwelling oriented between $45^{\circ}$ and $90^{\circ}$ prevaling wind.

Nonheated residential bullding spaces on windward. No points.

Maximum pitched roof areas and minimum wall areas on windward side of dwelling. No points.

Optimal wind protection to three sides of dwelling.

D. Shading

Outside shading devices used to shade major window areas from $10 \mathrm{~A} . \mathrm{M}$. to $5 \mathrm{P} . \mathrm{M}$. 


$$
76
$$

Deciduous trees used for shading placed in optimal location for summer shade.

Vines used on sunny brick, stone, or concrete walls. No points.

Grass used against dwelling rather than paving.

E. C1rculation and Parking

The street system that is adjacent to and serves ... .... No points.

III. Low and Moderate Income Housing (maximum 20 points) Not applicable.

Elderly low and moderate income 


\section{7}

At the initial public hearing, the RDEB notified Mr. Smith that he accumulated forty-eight (48) development points out of a possible elghty $(80)$ total points. This would leave Mr. Smith four points short of the standard of f1fty-two (52) points or (65\%) of the total eighty ( 80$)$ points. At this time, Mr. Smith notified the RDEB that he would be applying for a variance in order to receive the special permit.

At the varlance hearing, N.r. Smith presented a strong case on his behalf and was granted the variance enabling him to recelve the special permit. He was able to accomplish this by demonstrating how he pald a great deal of attention to the avallability of municipal facilities servicing his development and how he attempted to conserve energy wherever possible. In addition, Mr. Smith noted that "recreation" was the only category that he scored poorly on. However, he guaranteed the RDEB that he would supply a tot lot for his children and that the rest of his yard could serve for passive recreation. The RDEB concluded that Smith's development would not burden municipal services and granted him the special permit with the condition that he would supply the tot lot.

\section{EXAMPLE TWO}

Description of development

The Leonldas Development Corporation plans to construct Hoskins Estates--a 68-unit cluster development with the incorporated stated goal of energy conservation and design features. The developer intends a mixture of housing types and income 
levels. The breakdown of housing types is as follows:

1) 30- single fam1ly units

a. 18- 3 bedroom

b. $12-2$ bedroom;

2) 20- townhouse untts

a. $12-3$ bedroom

b. $8-2$ bedroom;

3) 12- moderate/1ncome un1ts

a. 6- 2 bedroom

b. 6- 3 bedroom;

4) 6- elderly moderate/1ncome units

a. 3- 1 bedroom

b. 3- 2 bedroom

Location of development

The development would be located on the south side of Camp Avenue, which runs off of Post Road, Just south of Quonset/Davisville. The land lies within plat 140. which is zoned planned village residential, except OS/PL: lots 2 and 3 and those portions of lot one below elevation $12 \mathrm{ft}$. above mean sea level. Parts of plats 107 and 141 are also involved. (Note: The particular land in question is currently owned by the General Services Administration of the Federal Government. Abandoned Navy housing occupies the site presently, along with the infrastructure needed for such a development. According to the North Kingstown Planning Department, this parcel of land w1ll be on the private market in a year (1979). Therefore, it is concelvable that in 1983, a developer would come up with

a plan for this area.)

Date of Application

July 1. 1983.

Sketch of development

See next page. 


\section{Key to Sketch}

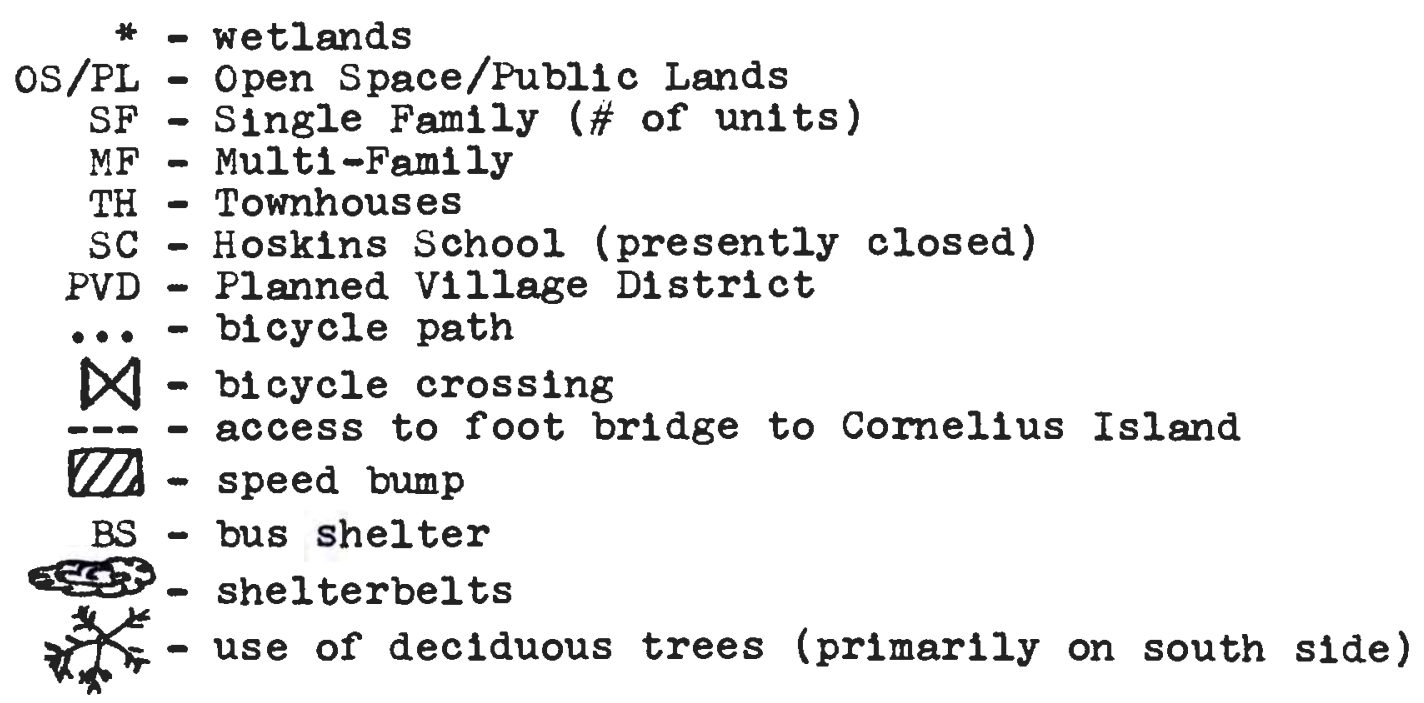

\section{Notes:}

Parking space is set aside for in lot arrangement.

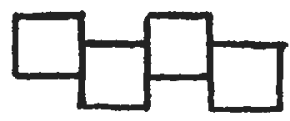

Arrangement of Townhouses.

Arrangement of Cluster Housing (Single Family, Multi-Family).

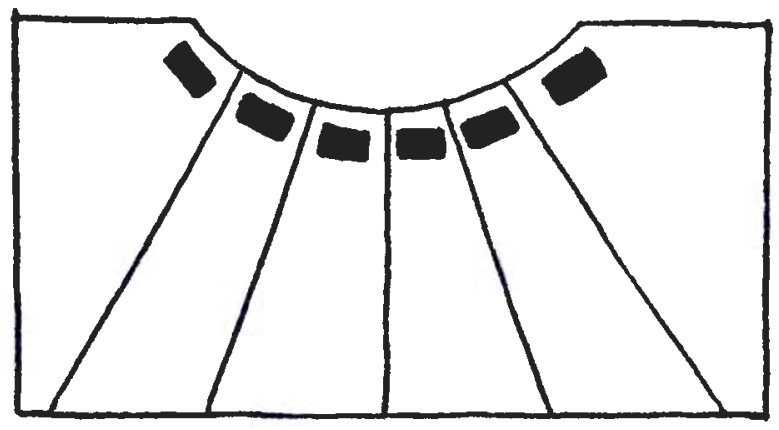




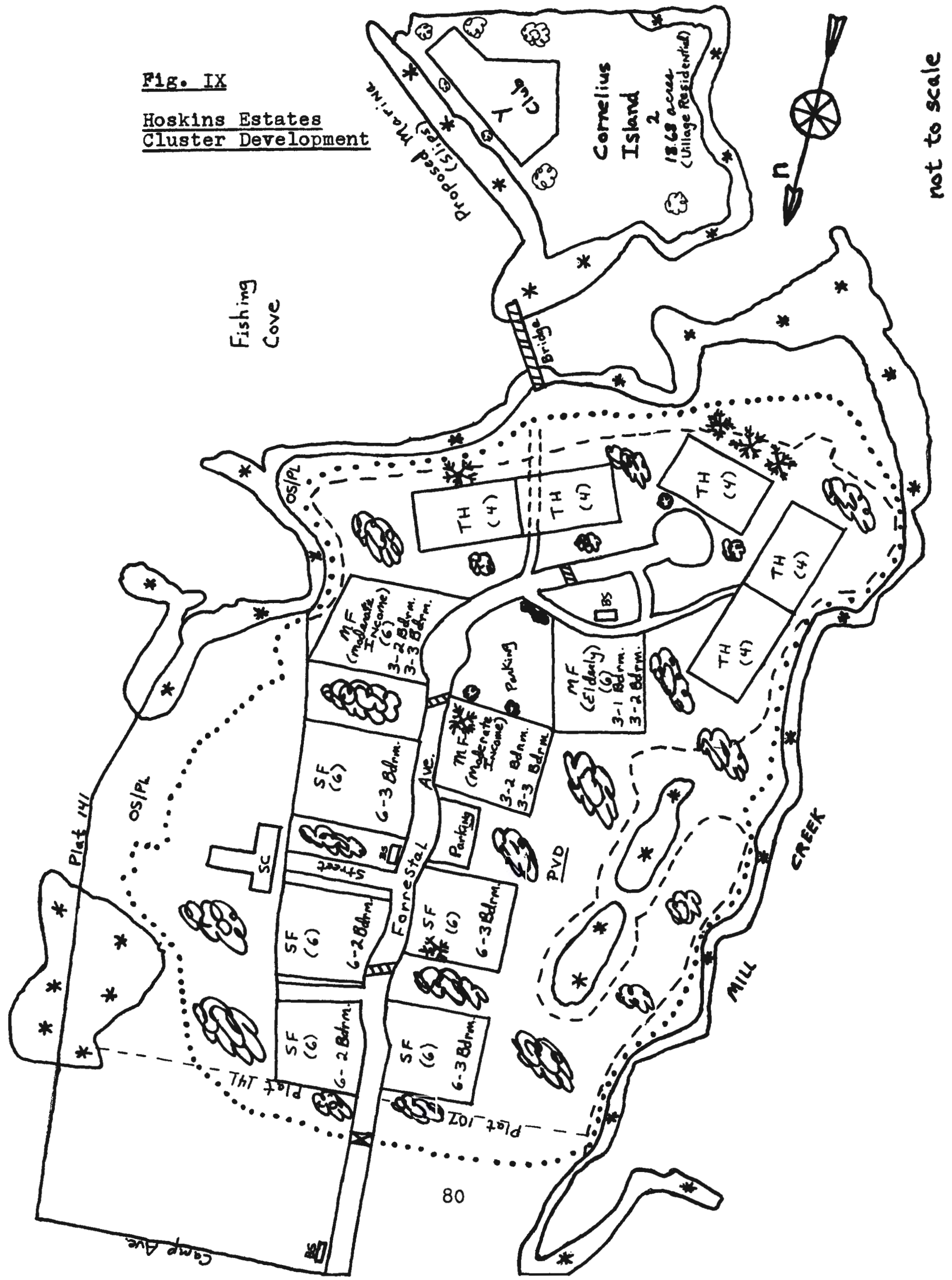


SCORE SHEET FOR SPECIAL PERMIT

(based on point system)

Name: Leonidas Development Corporation

Location: South side of Camp Avenue, $3 / 4 \mathrm{ml}$. from Post Road Date of Application: July 1, 1983.

I. Public Facilities

pts.

A. State, County, or Town Major Secondary or

Collector Roads

Direct access to Collector Rd., Camp Ave.

B. Improved Public Park or Recreation Fac1lity including Fublic School Site

The developer proposes to reuse the Hoskins Park Recreation area which is part of the site.

C. Fire Protection

Within three miles (approx. 2t miles) of station \#l on Post Road.

D. Water Distribution

Existing water mains and water system meet town standafds for water service and fire
protection.

E. Sewers

Sewerage is already avallable at the site.

F. Soll Constraints

slight. 5 
G. Police Protection

Development can be served by the existing personnel and facilities, and is within the existing service routes.

H. Flood Control

The development is in the floodplain

(Zones-A8-areas of special flood hazard. 8' flood elevation: $\mathrm{B}$ - areas of moderate flood hazard; $C$ - area of minimal flood hazard) and the developer proposes to constmact the necessary dralnageways.6

I. School Capacity

The developer intends on reopening the Hoskins school for private use to take care of the development's grade school children. Otherwise, the nearest school is the Davisville Elementary which is approx. 2 miles away.

J. Storm Drainage

The proposed land for development is already equipped for handling storm drainage because of the existing infrastructure. Any necessary improvements w11l be handled by the developer.

K. Public Transportation

Existing bus service exceeds $\frac{1}{2}$ mile from the development. No points.

II. Enersy Elements

A. Efficiency of Site Design

Clustered housing development which incorporates the stated goal of energy conservation and design features. 
83

The proposed development makes use of conservation measures by incorporating within the site and bullding design improved insulation, and the use of solar energy (all units).

B. Wind Protection for Developments

Most effective shelterbelts used and located where most of the development is w1thin 10-20 times the average helght of the shelterbelt.

C. Wind Protection For Individual Dwellings

Windscreen not applicable.

In general, no overall orientation to prevalling wind.

Not applicable. Nonheated spaces in various locations.

In general, a lot of wall space is on the windward side.

There is no optimal wind protection to individual sites. (re: three sides of bldg.)

D. Shading

Outside shading devices used to shade major window areas from 10 A.M. to 5 F.M.. Not applicable.

Deciduous trees used for shading placed in optimal location for summer shade.

Vines used on sunny brick, stone, or concrete walls. No points.

Grass used against dwelling rather than paving. 
84

E. Circulation and Parking

pts.

The street system discourages high speeds through the use of speed bumps and narrow streets. In addition, the development provides for alternative modes of transportation by providing on-site facilities for and external linkages with other modes of transportation $(e .8 .$. bus shelters, bike paths).

III. Low and Moderate Income Housing

Elderly low and moderate income

Six Elderly moderate income units

Moderate family income

Twelve units

Low family income

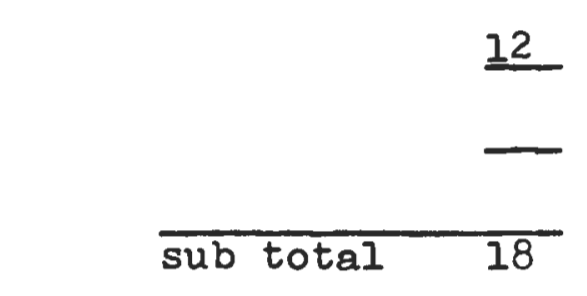


85

The developer, Leonldas Development Corporation, accumulated 75 points under the 100 point system. Th1s $75 \%$ f1gure represents a total exceeding the $65 \%$ standard. Therefore, the RDEB (Residential Development Evaluation Board) w11l grant the special permit. 
1. From Map of the General Plan of Water System, Town of North Kingstown, Town Engineering Department, 1974.

2. From Department of Housing and Urban Development, Federal Insurance Administration, Flood Hazard Map and Flood Insurance Rate Map for Town of North Kingstown. R.I.. 1976.

3. From Soll Conservation Service, west Warwick, R.I.. in cooperation with Rhode Island Statewide Planning. So1I Conservation Map and So11 Interpretations Table. 1975.

4. Town Engineering Department, op. c1t.

5. Department of Housing and Urban Development, Federal Insurance Administration. op. c1t.

6. So1l Conservation Service, West Warwick, R.I., in cooperation with Rhode Island Statewide Planning, op. cit. 
CHAPTER FIVE

CONCLUSIONS

In conclusion, we state that North Kingstown could enact a Growth Control Amendment to their Zoning ordinance, if the Rhode Island Land Management B11l were passed. We propose, as stated, that the Town could accomplish this through the use of a point system based upon three categorles, Public Fac1lities, Energy Elements, and Low and Moderate Income Housing needs. In addition. we recommend that the growth control program apply to all residential development, single fam1ly as well as larger scale developments. Where Do We Go From Here?

North Kingstown's Community Development Plan (1972) and the Zoning ordinance (1974) are two documents that reflect the policy of accommodating town growth within the natural constraints of the land and the town's financial power to make provision for adequate services and facilities.

It is evident that the Community Development Plan is a powerful land-use tool for directing where growth should occur and for regulating population density levels, but it is not a growth control plan. It does not take, for example, into consideration the "phasing" or "timing" of development in relation to an adequate provision of municipal services. Across the country, uncontrolled growth is being challenged and not 
solely on financial grounds. People are concerned with preserving their environment and in maintaining an acceptable "quality of 11fe." A basic issue for all residents of North Kingstown is: How are we to control future growth? Th1s issue along with others needs to be publicly discussed. In this town, "the established policies of town government reflect the traditional values and ways of a rural community." What actually exists, today, is a community of differing values which needs to be identified.

To bring the growth control ordinance to fruition. it is necessary to get the citizenry involved in the planning and decision-making from the start. Our proposed ordinance can provide the general framework in which discussion could ensue. We suggest the creation of a growth control committee which would serve as a forum for the discussion of land use policy in the town. It would be comprised of representatives of the various town agencles and goveming bodies, along with members of civic organizations and citizens-at-large. Fublic input would be sought through newspaper polls, public opinion surveys, hearings, and informal dinner discussions. Suggestions resulting from such a discussion could be used to update the Community Development Plan. A successful growth control ordinance would be dependent on the town's firm commitment to 1ts comprehensive plan.

The growth control committee could initiate a nonbinding referendum on the Town's ballot in deciding whether to 
89

institute a growth control ordinance. If the result is favorable, a binding vote could be taken at the next election. It would be extremely helpful to have a member of the town council advocate a controlled growth ordinance. This would stir further public debate. Quonset/Dav1sv11le

As stated in the Preface, our study has not dealt with the Quonset/Davisville area of town. However, the re-use of this land (whether it be industrial, commercial, recreational, residential, military, oll exploration, or any combination of the above) would have a definite impact on the town. In any event, with or without the re-use of Quonset/Davisville, North Kingstown will continue to grow quite rapidly. An environmental assessment study concerning the redevelopment of Quonset/ Davisville has stated likewise.

Population projections indicate that rapid development of the town will.occur regardless $8^{f}$ whether or not Quonset/Davisvilie is redeveloped.2

The re-use of Quonset/Davisville would intensify growth

in North Kingstown which would further burden municipal services. The report goes on to say that:

Expansion of economic activity at the site w1Il serve largely as a catalyst to this development. A rapid pace of growth poses several problems for North Kingstown. Providing adequate water, sewage disposal and solid waste disposal services to town residents are already problems; these pill all be aggrevated by rapid population growth. 3

Our growth control plan attempts, among other things, to combine rational land-use planning (specifically residential 
development) with capital improvement planning. The re-use of Quonset/Davisville will bring more growth necessitating the need for proper growth management. In fact, it can be generally stated that the redevelopment of Quonset/Davisville would make the need for a growth control plan all the more imminent.

The town cannot 18nore current and expected future growth. For those who wish to see North Kingstown remain the same or unchanged, a broader perspective is needed. We assume growth will occur and to be unprepared for 1t could be a costly mistake. To ensure the "quality of Iife" in North Kingstown, the town must plan ahead, not turn their backs on what may be inevitable. Our plan recognizes the interrelatedness of municipal delivery systems and takes into account energy needs and low and moderate income housing needs. The town has the facts and should move now to plan accordingly. Beyond 1993

Population projections beyond 1993 indicate that North Kingstown will continue to grow at a rapid pace. At the end of our fifteen year program the town could continue with a growth control strategy if needed. The question of length of time of the growth control program was one of the crucial points in the Ramapo court test. There the court ruled that their elghteen year program was a temporary restriction on land and therefore reasonable. Ramapo's growth control was an absolute system. North Kingstown may find that it would have more leeway if they desired to continue the plan. Our 
91

plan is more flexible and requires no mandatory quota on permits or absolute point total. In addition, we have provided sufficient remedies. 
1. Maintaining Community Identity in a Radically Changing Environment, North Kingstown Planning Forums, Sponsored by the Rhode Island Committee for the Humanities. Project Directors: Ellen Dodge, Principal Planner North Kingstown Planning Department, and Howard H. Foster, Jr.. Associate Professor of Community Planning. University of Rhode Island, June 1975. Introduction.

2. The Redevelopment of Quonset/Davisville: An Environmental Assessment. Prepared for The Rhode Island Department of Economic Development by The Coastal Resources Center. Graduate School of Oceanography. University of Rhode Island, 1977 . p. 60 .

3. Ibid.. p. 60 . 


\section{APPENDIX A}

MODEL GROWTH CONTROL AMENDMENT TO

ZONING ORDINANCE, NORTH KINGSTOWN

I. Legislative Intent

1. To control growth by insuring that the town w11l grow only at the rate it can meet the growing demand for services and finance necessary capital improvements.

2. To promote energy efficient development.

3. To adequately meet $l o w$ and moderate income housing needs.

\section{Definitions}

capital improvement program - refers to the three five year capital improvement plans or the overall fifteen year capital improvement program we propose for North Kingstown. Like all capital improvement programs, our proposal i1sts the schedule of capital improvements that are to occur in the town at a given point in time. (See Chapter Three, p. 45, Capital Improvement Program, for more information).

developer - the landowner, or person who acts as the landowner's authorized representative or agent who applies for a special permit to construct a residential development.

development - any plan by a landowner or his authorized representative or agent, to construct or place one or more dwelling units on a particular parcel of land within a particular area of the town.

development charges - the charging of the consumer and/or landowner (by the town) a price or tax of sorts in return for a service such as sewer, water hook-up, etc., etc. The town may have to compensate for this charge. (See the "remedy" section at the end of chapter three.)

landowner - the owner of a particular piece of property in the town.

low and moderate income housing - housing intended for low and moderate income people as defined by the particular federal, state, or local program. In the instance of private market low and moderate income housing, the most recent definitions of HUD and/or FHA should be used. 
point system - the method by which a landowner or his authorized representative (developer) seeks to be granted a special permit. In doing so the landowner or developer attempts to secure at least $65 \%$ of the sub-system point total.

remedy - the means employed to enforce or redress an injury. The most common remedy at law consists of money damages. 1

Residential Development Assessment Commission - Commission that determines the extent to which the temporary restriction on residential development use of the land shall affect the assessed valuation placed on the land for purposes of real estate taxation and such assessed valuation on such land shall be reduced as compensation for the temporary restriction placed on the land. Suggested composition - 6 members, 2 local bankers. 2 local real estate people, the Town Finance Director, and the Town Tax Assessor.

Residential Development Evaluation Board - The Board that issues the special permit. Suggested composition - 14 members, one chalrman appointed by the RDEB, 2 from the Town Council. 2 from the Planning Commission, 3 citizens from business and/or the professional area (e.g., energy expert). 2 from the local school board, 3 citizens at large, and the Town Bullding Inspector.

shelter belt - a mass of tree plantings used to reduce wind velocity.

special permit - the permit that a developer must obtain prior to issuance of any other general building permit, subdivision or site approval, or variance.

variance - a modification of the provisions of this amendment where strict enforcement of the amendment would cause undue hardship owing to circumstances unique to the individual property and do not occur generally to land or residences in the neighborhood. (See "varlance" section under "System operation" for a further explanation on variance).

wind screen - gives protection from the wind. A wind screen can be provided by a structural part of the building, a structure separate from the building, orientation of the building, plants, or any combination thereof.

III. System operation ${ }^{2}$

1. Creation and Powers of Residential Development Evaluation Board

There is hereby created a Residential Development Evaluation Board. which shall be independent of every other department and agency of North Kingstown. The 
Board w1ll have the authority to determine specific point totals on a given application for special permit. Furthermore, the Board w1ll have the authority to grant or deny the special permit. The Board will also have the authority to grant or deny a varlance to the requirements of this amendment.

2. Special Permit Required for Residential Development Use Prior to the issuance of any bullding permit, variance from the Platting Board of Review, sub-division approval, or site plan approval of the Planning Commission for residential development use, a residential developer or development agent shall be required to obtain a special permit from the RDEB.

3. Procedure for Special Perm1t

a. The residential developer or development agent shall be required to submit an application to the RDEB following regulations set forth by such Board. including a map showing the location of all land holdings of the applicant and the extent of the land proposed for development. The Board shall review the application with respect to all the standards set forth in the polnt system (4) as to the avallability of municipal services and facilities and projected improvements scheduled in the fifteen (15) year Capital Improvement Program of the town. In addition, the review process will take into account provision for low and moderate income housing and energy elements designed to conserve energy and promote the health, safety, morals, and general welfare of the community. The Board may request reports from appropriate town, state, or municipal agencies and boards, or officials as may be required. Applications for special permits will be accepted only b1-monthly, (Jan. 1, March 1, May 1, July 1, Sept. 1. and Nov. 1). Within thirty (30) days of the submission of the application, the RDEB shall come up with a report of 1 ts findings and the Town Clerk shall proceed to notice the application for public hearing not less than one (1) week after the compllation of the report and not exceeding two (2) weeks.

b. The RDEB shall after three (3) days after conclusion of the public hearing render its decision. In event of approval of the application without conditions. the $\mathrm{RDEB}$ shall also render its determination as to the number of residential dwellings that shall be built pursuant to the requirements of 7 . Vested Approvals and Rellef.

4. Standards for Issuance of Special Permit a. No special permit shall be issued by the RDEB unless 
the residential development has a standard of $65 \%^{3}$ of the total number of points. It should be noted that there exists two (2) point sub-systems, one based upon eighty (80) and one based upon one hundred (100) points. Those developers who w1sh to construct development or developments other than low and moderate income units. will be ellgible to accumulate elghty $(80)$ points based upon public facilities and energy elements. In this instance, the developer will be required to accumulate fifty-two points (52), or (65\%), of the total eighty $(80)$ points. Those developers who plan to construct any number of low and moderate income units will be judged on a one hundred (100) point system based upon all three categories, public facilities, energy elements, and low and moderate income housing. In this instance. the developer will be required to accumulate sixty-five points (65), or $(65 \%)$, of the one hundred (100) total points. (See 6. Variances for exceptions to this requirement). In the instance where low and moderate income housing limits have been satisfied, (See Chapter Three, D. Low and Moderate Income Housing), the point system will returm to an eighty $(80)$ point system based upon public facilities and energy elements only. The RDEB shall issue the special permit specifying the number of dwelling units that meet the standards set forth by this section.

b. No special permit shall be 1ssued by the RDEB unless the residential development has avallable sixty-five percent (65\%) of the total development points on the following scale of values:

(I.) Public Facilities

To encourage development on sites already served by existing utilities and services. Or to encourage developers to walt for the necessary improvements or to supply them themselves. (Maximum fifty (50) points). 5 pts. - A. $\frac{\text { State, County, or Town Major Secondary or }}{\text { Collector Roads }}$

$$
\begin{aligned}
& 5 \text { pts. - direct access } \\
& 3 \text { pts. - w1thin } \frac{1}{2} \text { mile } \\
& 1 \text { pt. - w1thin } 1 \text { mile } \\
& 0 \text { pts. - further than } 1 \text { mile }
\end{aligned}
$$

5 pts. - B. Improved Public Park or Recreation Fac1lity including Public School site

$$
\begin{aligned}
& 5 \text { pts. - within mile } \\
& 3 \text { pts. - within mile } \\
& 1 \text { pt. - within I mile } \\
& 0 \text { pts. - further than I mile }
\end{aligned}
$$


5 pts. - C. Fire Protection

5 pts. - within 1 mile

3 pts. - within 2 miles

1 pt. - within 3 miles

0 pts. - further than 3 miles

5 pts. - D. water Distribution

5 pts. - existing water mains and water system meet town standards for water service and fire protection, or such improvements are provided by the town at some point during the fifteen year Capital Improvement Program.

3 pts. - such improvements are provided by the landowner or developer.

0 pts. - where the above conditions are not met.

5 pts. - E. Sewers

5 pts. - public sewers avallable

3 pts. - state approved septic systems

3 pts. - package sewer plants

0 pts. - all others

5 pts. - F. S011 Constraints

5 pts. - slight

3 pts. - Moderate

1 pt. - Severe

0 pts. - Very Severe

5 pts. - G. Folice Protection

5 pts. - development can be served by the existing personnel and facilities. and is within the existing service routes.

0 pts. - development can be served by the existing personnel and facilities but an expansion of service routes is necessary.

4 pts. - H. Flood Control

4 pts. - if development is not in the flood plain or if it is, the town proposes to construct the necessary drainageway $(\mathrm{s})$.

2 pts. - if the developer proposes to construct the necessary drainageway(s). 
0 pts. - If development is in the flood plain and proposes no mitigating measures.

4 pts. - I. School Capacity

4 pts. - if a school serving the development is within $2 \frac{1}{2}$ miles and will not exceed the capacity limits of that facility.

2 pts. - if a school serving the development is within 5 miles and will not exceed the capacity Iimits of that facility.

0 pts. - if the development exceeds the capacity limits of the school serving it and/or is more than 5 miles away from that facility.

4 pts. - J. Storm Drainage

4 pts. - local drainage generated by the development will require no additional public improvements in order to carry the runoff to a receiving drainageway, or the town will provide the necessary improvements.

2 pts. - the developer will provide the additional public improvements that are required to carry the drainage generated by the development, 1.e.. catch basins, inlet structure, etc.. to a receiving drainageway.

0 pts. - where the above conditions are not met.

3 pts. - K. Fublic Transportation

3 pts. - existing bus service is within mile of the development.

1 pt. - existing bus service is within $\frac{1}{2}$ mile of the development.

0 pts. - existing bus service exceeds $\frac{1}{2}$ mile from the development.

\section{(II.) Energy Elements 4}

To encourage residential development to be efficient in terms of site design. building layout and orientation. and landscaping in order to promote maximum potential for energy conservation and so that the long term stability of the site and adjacent lands are secure and 
the overall community value enhanced. (Maximum 30 points).

4 pts. - A. Efflciency of Site Design (Maximum 8 pts.)

4 pts. - For planned unit developments (PUD) and clustered housing which incorporate the stated goal of energy conservation and design features.

4 pts. - Maximum use of conservation measures by incorporating within the site and bullding design improved insulation, and the use of solar or other non-fossil fuel source.

0 pts. - Does not consider the above.

2 pts. - B. Wind Protection for Developments

2 pts. - Most effective shelterbelts used and located where most of the development is within 10-20 times the average helght of the shelterbelt.

0 pts. - Does not consider the above.

2 pts. - C. Wind Protection for Individual Dwellings

(Maximum 10 pts.)

2 pts. - Windscreen used for a dwelling with optimal distance from dwelling (not further than 5 times neight or closer than $\frac{1}{2}$ times spread.)

2 pts. - Dwelling orlented between $45^{\circ}$ and $90^{\circ}$ prevalling wind.

2 pts. - Nonheated residential bullding spaces on windward.

2 pts. - Maximum p1tched roof areas and minimum wall areas on windward side of dwelling.

2 pts. - Optimal wind protection to three sides of dweling.

0 pts. - Does not consider the above.

2 pts. - D. Shading (Maximum 8 pts.)

2 pts. - Outside shading devices used to shade major window areas from 10 A.M. to 5 P.M.

2 pts. - Deciduous trees used for shading placed in optimal location for summer shade.

2 pts. - Vines used on sunny brick, stone, or concrete walls. 
2 pts. - Grass or other plant materials used against dwellings rather than paving.

2 pts. - E. Circulation and Parking

2 pts. - The street system that is adjacent to and serves the property, whether constructed by the developer or not: (I) discourages high speeds especially in situations where there is no physical separation (such as a wall) between the roadway and the development: (2) minimizes pedestrian-vehicular conflicts; and (3) provides for alternative modes of transportation by providing on-site facilities for and external linkages with other modes of transportation where applicable, 1.e.. bus shelters, bike paths, functional pedestrian circulation system.

\section{(III.) Low and Moderate Income Housing}

To provide needed low and moderate income housing (Maximum 20 points).

Type of Development

elderly low and moderate income

moderate income (non-elderly)

low income (non-elderly)
Points per/unit Maximum allowable pts.

5. Standards for measurements When distance, in miles, is involved, it shall be computed from the proposed location of each separate lot or plot capable of being improved with a residential dwelling and not from the boundaries of the entire parcel. The above will apply to all necessary measurements except when recreation sites are involved. In this instance, the measurement will be made from the residential development to the boundary of the recreation site. Measurements will be made along the shortest street route.? 
6. Variances

a. Procedure for hearing

In the Instance where a developer does not total the $65 \%$ standard, he or she may apply for a variance. A hearing will be called within 30 days after application for a variance has been submitted to the RDEB. All interested parties will be notified by advertisement in a local newspaper for two (2) consecutive weeks prior to the hearing. Abutters will be notified by mail. The decision of the RDEB will be given at the end of the hearing and will be considered final. Decision will be made by voting of the RDEB. At least nine (9) of the thirteen (13) members of the $\mathrm{RDEB}$ must be present to constitute a quorum. (There are 13 voting members and one chalrman who does not take part in the voting unless there is a tie, at which time the chairman will cast the deciding vote). A majority vote is needed to grant or deny the variance.

In case of local disagreement arising over the interpretation, application, or reasonableness of the zoning ordinance provisions, it is possible that any one might seek court review of the dispute.6

b. Criteria for evaluating variance

In evaluating whether or not a given developer shall receive a variance, the RDEB will consider to what extent the developer has met the following criteria.

1) The developer shall prepare a general policy statement explaining why he or she feels that the varlance should be granted.

2) The developer shall demonstrate how he or she has encouraged development on a site already served by existing utilities and services. Or the developer shall demonstrate how he or she will provide services.

3) The developer shall demonstrate how he or she has made the effort to conserve energy wherever possible.

4) If applicable, the developer w1ll demonstrate how he or she will supply needed low and moderate income housing.

5) The developer will prove how his or her plan is in accordance with the comprehensive Plan.

6) The developer w1ll prove how his or her plan is in accordance with the Town Zoning Ordinance.

7) The developer will prove how his or her plan is in accordance with Town Sub-Division Regulations or any other applicable state or local codes and regulations.

8) The developer will prove how his or her plan is in accordance with State Enabling Legislation and promotes the "general welfare." 
9) The developer w1ll prove how his or her plan has important economic, social, cultural, and/or aesthetic value for North Kingstown.

10) The developer w1Il prove that strict enforcement of the amendment would cause undue hardship owing to circumstances unique to the individual property and do not occur generally to land or residences in the neighborhood.

\section{Vested Approvals and Rellef}

a. Vested Approval of Special Permits When any number of development points are obtained in category I. Public Facilities, in combination with either or both of the two additional categories, the following conditions shall exist.

The RDEB shall issue an approval of the application for special permit vesting a present right for the residential developer to proceed with residential development use of the land for such year as the proposed development meets the required points as indicated in the scheduled completion dates of the Capital Improvement Program. Any improvement scheduled in the Capital Improvement Program for completion within one year from the date of application for special permit shall be credited as though in existence on the date of applicat1on. Any improvement scheduled in the Capital Improvement Program more than one year from the date of application shall be credited as though in existence as of the date of the scheduled completion.

b. A developer may advance the date of authorization by agreeing to provide such improvements as will bring the development within the standard number of points for earlier or immediate development. (When a developer supplies such improvements or services it is assumed that the facility will be in working order or operation. In other words, the developer (for example) who supplies a fire station will not recelve the corresponding number of points unless the station is in operation including the necessary equipment and staff, either supplied by the town or developer.). Such agreement shall be secured, by the developer, by elther a cash deposit or surety bond sufficient to cover the cost of the proposed improvement, the form, sufficiency. and amount of which bond shall be determined by the RDEB.

c. Relief

Any residential developer or agent who has applied for a special permit from the $\mathrm{RDEB}$ shall be entitled, as their right, to appeal within one year from the $\mathrm{RDEB}$ determination granting vested approval to the Fiesidential Development Assessment Commission for a determination as to the extent to which the temporary restriction on residential development use of the land shall affect 


\section{3}

the assessed valuation placed on the land for purposes of real estate taxation and such assessed valuation on such land shall be reduced as compensation for the temporary restriction placed on the land. 
1. Steven H. Gifis, Law Dictionary, Barron's Educational Series, Inc., Woodbury, N.Y., 1975, p. 176.

2. The System Operation is modeled after the one set up in Ramapo, N.Y. (see: Ramapo, N.Y.. Zoning Amendment Conditioning Development Permits on Adequate Public Facilities 46-13.1. A slight variation was used. The 1dea for the RDEB comes from the system used in Petaluma, California. The idea for the Residential Development Assessment Commission comes from the Ramapo ordinance. The actual "point system" is a synthesis of the Ramapo system and the Boulder, Colorado growth control ordinance with a few of our own 1deas as well.

3. Ramapo Amendment, op, c1t.

4. The standards in this category follow very closely those set up under the "State of Vermont Energy Conservation Guldelines," prepared by the Vermont Public Service Board and the Agency of Environmental Conservation (Montpelier. Apr1l 1974): Section E - Cfrculation and Parking follow City of Boulder, Colorado, Ordinance No. 4208, 1977.

5. Dr. Norman Slovik, Deputy Supervisor, Ramapo, New York supplied us with this information concerning measurements.

6. This rather standard language was taken from William I. Goodman, ed.., and Er1c C. Freund, assoc.. ed.. Principles and Practice of Urban Planning, published for the Institute for Training in Municipal Administration by the International City Manager's Association, 1968, p. 441. 
APPENDIX B

LEGAL CONSIDERATIONS

\section{Introduction}

Assuming the Town of North Kingstown, Rhode Island wants to control the timing and location of its development: 1) does 1t possess the express statutory authorization to adopt a controlled growth ordinance?; and, 2) if so, what legal issues would be ralsed by such a scheme? The question of whether the power to time development was delegated from the state to a municipality was raised as a legal issue in

Golden v. Planning Board ${ }^{l}$ - the now famous case which challenged Ramapo. New York's power to time its development in relation to its level of public services. This 1ssue, among others raised by Golden. will be examined in relation to our situation. II. Police Power: Delegated From The State

State government in Rhode Island is constitutionally involved with land use planning. The State Constitution requires the General Assembly "to provide for the conservation of air, land, water, plant, animal, mineral, and other natural resources...by providing adequate resources planning for the control and regulation of the use of natural resources of the state." In short, land is a natural resource for which the General Assembly is responsible. Such responsibility is delegated via police power from the state to local governments 
through state enabling laws.

In determining whether North Kingstown possesses express statutory authorization to draft and enforce a controlled growth zoning ordinance, one must examine the proposed State Enabling Act (27 H-6299 - An Act Establishing a State/Local Land Management Program) which is before the General Assembly, and, if passed, would replace the present Act on zoning and subdivisions. The authors of the bill state that it is needed "to assure that development is related to the level of public services and to encourage more compact development." 2 At present, enabling legislation does not provide municipalities in Rhode Island with the authority to deal with the broad range of land use problems and allow for variety and a choice of methods. The proposed Act is designed to alleviate this problem.

It is important to note that the Rhode Island Supreme Court in 1961.3 and again in 1976. 4 made its position clear that city or town ordinances cannot exceed the authority conferred by the enabling legislation.

A. 27-H-6299 An Act Establishing a State/Local Land Nanagement Program

After close examination of $77 \mathrm{H}-6299$, one finds no specific statutory reference to regulating the "timing of development" though its objectives are incorporated in the general language of the proposed Act. For this reason, there is a strong argument to justify a well-thought out scheme to provide for such regulation. 
The following sections of $77 \mathrm{H}-6299$ are related either directly or indirectly to the "timing of development."

Chapter 1. Land Use Pol1cy-

28.1-1-2 Leg1slative Intent-(5) (to) provide c1ties and towns with enabling legislation for planning and land management that gives them authority to deal with the full range of land use problems and that allows for diversity and choice of methods.

28.1-1-4 State Land Management-Purposes and Scope- (a) purposes - address land use 1ssues of statewide concern including: (1) the relationship of development to avallability of public facilities and services.

28.1-1-6 Local Land Management-Purposes and Scope- (a) purposes - land management by citles and towns shall promote the public health, safety, and general welfare by being designed to: (2) relate the use of land to 1ts physical characteristics and capabilities and to the avallability of public facilities and services.

Chapter 2. General Land Use Standards-

28.1-2-1 Purpose of General Land Use Standards-Standards are intended to maintain a distinction between urban and rural environments and to relate the type and intensity of recommended development in each land use category to the physical capabilities of the land, the level of public facilities avallable or planned, and the land requirements of different activities.

28.1-2-2 Establishment of General Land Use Standards- (a) Land Use Intensities - Each c1ty or town shall demonstrate that 1 ts land management ordinance, and the land management plan with which it must be consistent, established categories of land use intensity. Such categories shall be based on the following three criteria: first, the ability of the land to support development in terms of soll suitability, potential air and water pollution, landscape features, and other natural or physical characteristics; second, the extent of present and proposed public water and waste disposal facilities and where feasible to use as criteria, the extent of other community services such as education, police, and fire protection, transportation, and utilities; and third, the present uses and needs of land for residential, commercial. industrial, recreational, agricultural. and other activities, and the interrelationships of these activities.... 
A city or town may control the types of categories by timing of public facilities and by other planning....

Each city or town shall classify all land within its jurisdiction as urban, transitional, and/or rural, as appropriate to 1 ts particular characteristics and land use objectives....

\begin{abstract}
....The intent of the transitional land use category (which constitutes much of North Kingstown) is to allow for areas that are approaching urban conditions in the sense of both space and time; they are on the fringes of urban land, and in the future they will become urban as development continues.
\end{abstract}

Especially in transitional areas, the most dynamic land use category, local land management plans and ordinances shall carefully coordinate the time, location, and design of development and public services so that adequate services are provided and impacts on the natural and cultural environment are minimized.

28.1-2-4 Local Consistency w1th General Land Use StandardsA city or town may utilize any type of land use control that it chooses, as privided in 28.1-7-3, so long as its land management ordinance is consistent with the general land use standards.

28.1-6-8 Short-term Program- (a) Requirement-A community gulde plan shall include a short-term program of specific public actions to be undertaken in stated sequence by specified government agencies in order to achieve goals, objectives, policies, and standards stated in the community guide plan, land management plan, or other element of the suide plan; (b) Relationship to Capital Improvement Program.-The short-term program shall cover a period of time to be specified in the community guide plan. The program may be coordinated with, or be part of or include a city or town capital 1mprovement program and may be prepared within the framework of a long-range program, thereby indicating the general nature of future actions. (etc.)

28.1-7-3 Ordinance Provisions- (2) restricting buildings, structures, land uses, and other development by performance standards related to air and water pollution, noise and glare, soll erosion, and sedimentation. burden on public services, and other effects; (6) insuring proper scheduling of development and open space preservation. 
B. Proposed Revisions of $27 \mathrm{H}-6299$ to Provide Specific Statutory Authorization

It appears that section $28.1-2-4$, entitled Local Consistency w1th General Land Use Standards, conflicts with the "diversity and choice of methods" envisioned under section 28.1-1-2 Legislative Intent, by limiting the type of land use control that may be utilized in section 28.1-7-3 Ordinance Provisions. Of the twelve categories set up from which a local ordinance may contain provisions for, only two are vaguely related to the "timing of development." (See relevant categories of 28.1-7-3 in A.) By definition, performance controls constitute a different tool for guiding growth and change in contrast to phased growth ordinances. 5 Insuring proper schedulling of development and open space preservation refers to the normal subdivision control process and 1 ts concern for how a development is laid out. Such a process does not automatically take into consideration the question of "where" and "when" a development will be lald out.

Specific statutory authorization needs to be spelled out for phased growth controls.

28.7-7-3 Ordinance Provisions- A land management ordinance may contain provisions for:

Amend (13) regulating the timing and location of development in order to secure economy in the provision of municipal services and facilities at a high level; maintain these services and fac1lities at a high level; control the character of development; maintain a desirable balance of land uses; and, thus protect the public interest.

28.1-7-8 Permit Conditions- (b) Special development- A special development permit may contain conditions relating to any matter subject to regulation under this act, including a means for: 
Amend (7) relating the availability of municipal services and facilities and projected improvements scheduled in the capital budget and capital plan to the level of residential, industrial, and commercial development.

After having made such revisions, it can be argued that the proposed State Enabling Act ( $27 \mathrm{H}-6299)$ provides the cities and towns of Rhode Island with the express statutory authority to draft and implement a controlled growth zoning ordinance. III. Legal Issues Raised by Timing Controls

In Golden V. Flanning Board, the plaintiff's challenge ralsed four main 1ssues. They were: 1) the power to time development was not delegated to Ramapo by the state;

2) assuming Ramapo had authority, the town's zoning laws had not been adopted in conformance w1th a comprehensive plan; 3) the plaintiff's 14th Amendment right to due process was infringed upon because the zoning plan was both exclusionary and a taking without just compensation; 4) classifications in the ordinance were unjustiflably discriminatory, therefore, they were violative of the equal protection clause. ${ }^{6}$ The Golden court rejected this challenge, nevertheless, it raised some very interesting issues.

A. Time Control and State Law

1) Background?

Issue: Zoning is an unconstitutional infringement on property rights without just compensation.

1926- Village of Euclid, state action which created local use, helght, and area districts did not automatically infringe upon 14th Amendment rights. (V1llage of Euclid v. Ambler Realty Co., 272 U.S. 365 (1926). With the general constitutional basis for 
zoning established, critics shifted to arguments grounded in state law. (Nectow v. City of Cambridge. 227 U.S. 183 (1928): The government power to interfere by zoning regulations with the general rights of the landowner by restricting the character of his use is not unlimited and cannot be imposed if it does not bear a substantial relation to the public health. safety, and welfare. Here the court sald that the effect of a zoning ordinance that separated a 100foot strip from the remaining portion of a property rendered the strip of little value for the limited purposes permitted by the ordinance.

Municipalities such as Ramapo, New York can enact a zoning ordinance but only in accordance with powers delegated to them by state enabling legislation. A town may have the power to promulgate ordinances but not specifically timing controls. One must ask: Is there express statutory authorization for such a purpose?

A relevant 1ssue ralsed in Golden. In response to such a question. was "whether the power to regulate the sequence and timing of development could be implied when the exercise of that power would serve an enumerated zoning purpose." The Court of Appeals broadly interpreted the enabling legislation. This occurrence is consistent with a developing trend in land use controls which calls for flexibility and a mix in the choice of zoning techniques. 8

Golden does not allow a town to zone for unlimited purposes. The requirement that the ordinance be in accordance with a comprehensive plan limits municipal authority. Constitutional considerations also limit the means selected. B. Requirement That Zoning Be In Accordance with a Comprehensive Flan

1) Linking the Means w1th the Ends 
One must know the intent of an ordinance to evaluate 1t legally. What goals and objectives does $1 \mathrm{t}$ incorporate? A fundamental principle used in Golden was: zoning may be used only to remedy problems "pecullar to the locallty's basic land use scheme."9 Most state zoning enabling acts require that zoning ordinances and changes must be adopted "In accordance with a comprehensive plan." The present enabling legislation in Rhode Island is no exception. ${ }^{10}$ Courts in Rhode Island have upheld the constitutionality of this rule of statutory construction. 11

a. Defining a Comprehensive flan (master plan, zoning law, capital budget and plan, maps, etc.) Requirement: some planning process--evidence that forethought and consideration of what would further the health, safety, morals, or welfare of the community has preceded the enactment to, the zoning ordinance. ${ }^{12}$

b. Protecting the Public- A comprehensive plan functions to provide special protection to landowners who might otherwise be exposed to arbitrary zoning regulations. When a zoning ordinance is found to conflict with an existing comprehensive plan, the ordinance must be judicially invalidated. ${ }^{13}$

2) Neeting the Requirement in Golden- A comprehensive plan did exist. Because the plan was directed at insuring controlled growth throughout the town and the adequate provision of municipal facilities and services to meet the resulting public need, the challenged time controls and the comprehensive plan did not conflict. 


\section{3}

C. Constitutional Criter1a 14

\section{1) Substantive Due Process}

Zoning is a government restriction upon a landowner's constitutionally protected freedom to use his property as he pleases. How far can a regulation go?

In Golden, the court examined whether the effective ends served by time controls were included in the state's police powers. Were time controls on land use a means so unreasonable as to effect a taking of Golden's property without compensation?

\section{A. Constitutional Limitations Upon Zoning Ends- Exclusionary Zoning}

National Land and Investment Co. V. Easttown Townsh1p Board of Adjustment (419 Pa. 504, 215 A 2d 597 (1965)) - The Pennsylvania Supreme Court held that Easttown Township's 4acres minimum lot requirement had such an exclusionary effect, not justiflable as an attempt to further the health, safety. morals, or general welfare of the community, and was therefore, in violation of the due process clause. ${ }^{15}$ The court in National Land concluded that the minimum lot size was not necessitated by considerations general to the town but "simply a matter of private preference," an interest not effectuated by zoning. The court indicated that the private $v$. public purpose test varies with the land involved and the circumstances of each case.

"Zoning is a means by which a government body can plan for the future-it may not be used as a means to deny the future."16

In determining the validity of land use limitations. 
the court, in Golden, stated that "what segregates permissible from unpermissible restrictions, depends in the final analysis upon the purpose of the restrictions and their impact in terms of both the community and general public interest."17

The Golden court concluded that the restrictions imposed by the Ramapo ordinance were "aimed at population assimilation. not exclusion," and the law was therefore upheld.

Ramapo's controlled growth ordinance is not designed to halt the flow of racial and economic minorities into the community. The town provided for their assimilation by developing and moving to implement a plan for low-income housing. The intent of the Ramapo plan is to insure the adequacy of future facilities modified only by a concern with the immediate excessive demand that accompanies unlimited growth.

When exclusionary zoning is looked at in a much broader sense, Ramapo's scheme becomes questlonable. It has been suggested, by one court, that each town has an obligation to bear a falr share of the burden resulting from regional development. 20 In fact, Berenson v. Town of New Castle, 21 does limit the Ramapo approach by stating that local "time phased" development must consider regional needs.

An otherwise valld ordinance may be judged exclusionary if it shifts a town's burden of urbanization onto neighboring municipalities. The New York University Law Review states:

In terms of an analysis of time controls, zoning courts should first, focus upon the dimensions and timing of the town's eventual population assimilation, and, secondly, determine the reasonableness of the given zoning program in light of projected regional housing needs and the municipality's location, size, and 
suitability for residential development. The Ramapo ordinance was not subjected to this sort of judicial scrutiny and the lawfulness of time controls modeled after this zoning approach must therefore remain

B. Time Controls-A Means Reasonably Calculated To Achieve Valid Zoning Ends. 23

The court found phased growth to be "well within the ambit of existing enabling legislation." (30 N.Y. 2d at 376,285 N.E. $2 d$ at $300,334, N . Y . S .2 d$ at 150 ) and 1 ts purpose that of achieving "a balanced cohesive community dedicated to the efficient utilization of land," (Id. at 378, $285 \mathrm{~N} . \mathrm{E} .2 \mathrm{~d}$ at 302, 334, N.Y.S. 2 d at 152 ) constitutionally valid. The court was faced with deciding whether the means employed were so unreasonable as to violate substantive due process. In reaching its conclusion, the court applied the presumption of validity which accompanies the exercise of police power. They held Ramapo's plan to be a means reasonably calculated to effect the community objectives of systematic, orderly development. (30 N.Y. 2d at 378, 285 N.E. 2d at 302,334 N.Y.S. $2 d$ at 152 ).

C. Time Controls- A Means So Unreasonable As To Effect A Taking without compensation

a) The Applicable Test

An ordinance may impose a restriction so oppressive as to effect a taking which constitutionally requires compensation. (See Goldblatt v. Town of Hempstead. 369 U.S. 590. 594 (1962).) The line between a valid restriction on private land use and a confiscation requiring compensation is of ten 
difficult to draw. An ordinance which furthers some legitimate public interest is not confiscatory just because it works to lessen the value of the burdened property (Euclid). The Supreme Court ruled in favor of a zoning ordinance which the plaintiff proved reduced the value of his property by $75 \%$ (Goldblatt). But, as the public benefit lessens and the damage incurred by the property owner increases, regulation turns into taking. (See for e.g., Pennsylvania Coal Co.v. Mahon, 260 U.S. 393 (1922)). There is no firm rule to follow in this area of law. It is a matter of degree--a balance between the loss of property value and the benef1t of the regulation to the public.

Some argue that the test to determine taking (balancing test) has no historical validity nor special validity and should be abandoned. (See Fred P. Bosselman et. al., The Taking Issue, prepared for the U.S. Government Printing office, (1973): and, Edward, "The Taking Issue," 5 Environmental Law 515 (1975)). They suggest that just as government can strictly regulate commerce without compensation, it should also regulate land without fear of a taking challenge and invalidation of the regulation even though the regulation may result in denying use of the property for a profitable purpose. Compensation should be required only where the government physically invades or confiscates property, otherwise, the legislature should determine whether or not and how much it wants to compensate property owners whose land is subject to regulation. 
Other experts disagree that regulation can never result in a taking. (One land use expert who holds this point of view is Professor Norman williams, Jr.; see williams, American Land Planning Law, Vol 5. 162.06. Chicago: Callaghan and Company. 1975. pp. 438-39). They subscribe to the balancing theory. They wish that courts would be more explicit in setting standards.

b) Golden: Ramapo's Timing Controls Not a Taking 25

In Golden, the Court of Appeals held that the restrictions upon subdivisions and development imposed by the Ramapo ordinance did not constitute a taking without compensation, even though some land might be burdened for a full generation. (30 N.Y. 2d at 383, 285 N.Z. 2d at 304-05. $334 \mathrm{~N} . Y . S .2 d$ at 156). Rationale: The value of the Golden property had not been permanently impaired, the limitations were not endless since the comprehensive plan revealed that all residential property could be subdivided within a maximum period of eighteen years. In addition. Golden would hasten the time of development of her property by providing, at her own expense, the facilities and services required by the ordinance. ( $30 \mathrm{~N} . \mathrm{Y}$. $2 \mathrm{~d}$ at $382,285 \mathrm{~N} \cdot \mathrm{E} .2 \mathrm{~d}$ at $304,334 \mathrm{~N} . \mathrm{Y} . \mathrm{S} .2 \mathrm{~d}$ at 155). In declding upon the extent to which the value of the Golden property was lessened, the court found the possibility that she would actually derive financial benefit from the "timed" development of the town and her reduced local property taxes during the period of restriction.

\section{Equal Protection Argument}


The 14th Amendment of the United States Constitution requires that all people be treated equally under the law unless classification with different treatment for each class is necessary to achieve a permissible state objective. In accordance with constitutional doctrines, only those classifications which are arbitrary and unreasonable will be in violation of this protection. 26

Equal protection questions raised in Golden were:

1) the statutory distinction between "developers" and single-plot developers was arbitrary and caused the law to be unconstitutional; and,

2) the statute was "discriminatory in fact" since development priorities were first afforded to those who owned property located closest to municipal facilities, while the right of development was deferred for those owning land on the outskirts of town. 27

The Ramapo zoning ordinance associated two classes of property owners and apparently treated them differently: those who want to subdivide their parcel of land and erect buildings must obtain the special permits; those who wish to build a single dwelling on an existing undivided parcel of land are not so required.

Was this a reasonable classification? What are the stated goals of the Ramapo ordinance? The goals are: 1) to economize on the cost of providing municipal facilities and services; 2) to maintain control over the eventual character of development; 3) to maintain a desirable balance among the various land uses, and; 4) to maintain the quality of community services and facilities. The court ruled that the distinction did not appear so unrelated to the zoning purposes as to be arbitrary and unreasonable. 
IV. Concluding Remarks

It is clear that even if the Town of North Kingstown has express statutory authorization to set up a controlled growth ordinance, it must be in accordance with a "comprehensive plan" and the means selected will be limited by constitutional considerations.

Rhode Island courts have required that a zoning ordinance must be based on a comprehensive plan. In Robinson v. Town Council of Narragansett $(60$ R.I. 422, 434), the court sald: "Zoning laws are generally enacted for the purpose of dividing the territory of a community on a comprehensive plan into use districts, each with designated standards, with the object of conserving and assuring the health, safety, and welfare." The court goes on to say in Robinson ( 60 R.I. 422, at page 437):

Such laws are not designed to protect some individuals to the detriment and hardship of others. The regulatory restrictions which a zoning law may properly enforce on the use of land by its owner must. in some substantial manner, tend to promote the common good of all the people in a community rather than to further the desires of a particular class, group. or individuals in the community.

Zoning ordinances are subject to various legal challenges such as being exclusionary, as a taking without just compensation, and a question of whether the zoning ordinance embodies valid ends.

Zoning ordinances will be sustained unless it can be shown that there is no substantial relation between such ordinance and any of the general objects of the enabling Act. 
In Harte V. Zoning Board, ( $80 \mathrm{R}$.I. 43 at page 51), the court indicated strongly that a zoning ordinance must be read in connection with the Enabling Act which authorized such ordinances. Not only are zoning ordinances presumed to be valid. but they are also presumed to be consistent with the enabling statute. But since zoning ordinances are in derogation of the common-law rights attaching to private ownership of land, they are given a strict interpretation. (See: Lamothe v. Zoning Board of Cumberland, 81 R.I. 96, 101).

Under the rule of strict construction, a zoning ordinance will not be extended or enlarged, by implication to include anything that does not fall within its express statutory provision. (See: City of Warwick V. Campbell, 82 R.I. 300). 
APPENDIX B

ENDNOTES'

1. 30 N.Y. 2d 359, 334 N.Y.S. 2d 138, 285 N.E. 2d 291 (1972).

2. See Folder distributed by Rhode Island Statewide Planning Program, 265 Melrose Street, Providence, Rhode Island, 02907. entitled Rhode Island's Land Management Legislation.

3. Cianciaralo V. Tarro (92 R.I. 352, 168 A 2d 719). Local legislatures have no authority to enact zoning regulations or amend existing zoning regulations other than that conferred upon it in the pertinent provisions of the enabling legislation.

4. Camara v. Warwick ( R.I._- 358 A 2d 23). A zoning amendment is a legislative act and as such the amendment can go no further than the enabling act.

5. Performance Controls- approach : review projects against various standards rather than stating what type and size of structure may be built in an area before its potential impacts are evaluated. This review attempts to measure the impacts various types of new development might have on the land itself and on the municipal services required to accommodate the change; difficulty: regardless of the indicators chosen, embarking on this sort of approach involves setting a lot of standards without necessarily having adequate data to do so, and then prepared to interpret them-for they will be challenged.

Phased Growth Ordinance- approach: unlike some of the more stop-gap methods attempting to manage growth by merely putting a celling on sewer hookups or bullding permits, this approach represents a serious effort to ensure that new residential development colncides with other local planning goals. Ideally, under a phased growth ordinance, a plan would exist to project not only expected population increases, but also required capital outlays for municipal services and specific improvements. The actual phasing of new units would follow the constraints and opportunities spelled out in the plan.

6. New York University Law Review, "A Zoning Program for Phased Growth: Ramapo 'Township's Time Controls on Residential Development," 47: October 1972, pp. 723-60. This Law Review is used extensively as a guide in discussing legal issues.

7. Ibid., pp. 730-31.

8. See American Law Institute's, A Model Land Development Code, adopted at Washington, D.C.. Hay 21, 1975. Library of Congress Catalog Number: 76-29574, which proposes the complete delegation of zoning power so as to authorize control and regulation of land use and development for any constitutional purpose. 
9. Golden V. Planning Board, $30 \mathrm{~N} \cdot \mathrm{Y}$. 2d at $371 \mathrm{~N} \cdot 5.285 \mathrm{~N}$. . 2d at 297 N.5. 334 N.Y.S. 2d at 146 N.5.

10. G.L, 45-24-3 (2956)- "Such regulations shall be made in accordance w1th a comprehensive plan...."

11. See Robinson v. Town Counc1l of Narragansett, 60 R.I. 422 , 434 ; and Camara v. Warw1ck. (1976) _R.I.__. $358 \mathrm{~A}$ 2nd 23.

12. For example, see Albright $v$. Town of Manlius, $34 \mathrm{App}$. D1v. 2d 419, 423. 312 N.Y.S. 2d 131, 18 (4th Dept. 1970), Off'd 28 N.Y. 2d 108, 268 N.E. 2d 785. 320 N.Y.S. 2d 50 (1971).

14. New York University Law Review, $47:$ p. 743.

15. Id. at $533,215 \mathrm{~A} 2 \mathrm{~d}$ at 612 .

16. $419 \mathrm{Fa}$. at $528,215 \mathrm{~A} 2 \mathrm{~d}$ at 610.

17. 30 N.Y. $2 d$ at 378,285 N.E. 2d at 302,334 M.Y.S. 2d at 152 .

18. 30 N.Y. $2 \mathrm{~d}$ at $376,285 \mathrm{~N} \cdot \mathrm{E}, 2 \mathrm{~d}$ at 300,334 N.Y.S. $2 \mathrm{~d}$ at 150 .

19. New York University Law Review, 47: pp. 747-748.

20. Oakwood at Madison, Inc., v. Township of Madison, $117 \mathrm{~N} . \mathrm{J}$. Super II, 20-2I, 283 A 2d 353, 358 (L. Div. 1971).

21. 378 N.Y.S. 2d 672 (1975).

22. New York University Law Rev1ew, $47:$ pp. 749 .

23. Ib1d., p. 749 .

24. Ibid.. pp. 750-751.

25. Ibid., pp. 753-754.

26. See F.S. Royster Guano Co. V. Virginia, 253 U.S. 412,415 (1920): Rules for testing a discrimination set forth in Lindsley V. Natural Carbonic Gas Co., 220 U.S. 61 (1911).

27. New York University Law Rev1ew, 47 : p. 758. 


\section{APPENDIX C}

CAPITAL IMPROVEMENT PROGRAM DATA

\section{Pol1ce}

In relation to our point system, service routes are important in determining the future demand for police service. As mentioned previously, service route data was not avallable to us. To make things easier, instead of expanding service districts, it was assumed that a constant level of service would be maintained per capita, along with no outside economic Influences. Therefore, future need for police vehicles would be equated with population growth.

Fresently, there are twelve cars in the North Kingstown police force. With 23.500 people in the town by June 30.1978 , this breaks down to approximately 2,000 people per car. Based on the following data, a single police vehicle was added for approximately each population increase of 2,000. The town is spending around $\$ 30.00$ per person $(\$ 709.571 / 23.500=\$ 30.00$; or FY 77-78/ Population on June 30. 1978) in maintaining the current level of service. This $\$ 30.00$ figure will be used as the standard throughout to calculate the projected budget. 
Popula- Cap. Feriod July 1 June 30 stand. tion Budget Increase Expend. Acquis'n

\begin{tabular}{|c|c|c|c|c|c|c|c|}
\hline $\begin{array}{l}\text { Present } \\
\text { I. }\end{array}$ & $\begin{array}{l}1977 \\
1978 \\
1979 \\
1980 \\
1981 \\
1982 \\
\end{array}$ & $\begin{array}{l}1978 \\
1979 \\
1980 \\
1981 \\
1982 \\
1983\end{array}$ & $\begin{array}{l}30 \\
30 \\
30 \\
30 \\
30 \\
30 \\
\end{array}$ & $\begin{array}{l}23.500 \\
24.700 \\
25.700 \\
26.700 \\
28.500 \\
30.500 \\
\end{array}$ & $\begin{array}{l}709.571 \\
741.000 \\
771.000 \\
801.000 \\
855.000 \\
915.000\end{array}$ & $\begin{array}{l}\$ 31.429 . \\
\$ 30.000 \cdot \$ 6.000 \\
\$ 30.000 . \\
\$ 54.000 . \$ 6.000 \\
\$ 60,000 . \$ 6,000\end{array}$ & $\begin{array}{l}12 \\
-- \\
13(+1) \\
-- \\
14(+1) \\
15(+1)\end{array}$ \\
\hline$\overline{I I .}$ & $\begin{array}{l}1983 \\
1984 \\
1985 \\
1986 \\
1987\end{array}$ & $\begin{array}{l}1984 \\
1985 \\
1986 \\
1987 \\
1988\end{array}$ & $\begin{array}{l}30 \\
30 \\
30 \\
30 \\
30\end{array}$ & $\begin{array}{l}32.000 \\
33.500 \\
35.000 \\
36.200 \\
32.700\end{array}$ & $\begin{array}{l}\$ 960,000 \\
1.005,000 \\
\$ 1.050,000 \\
\$ 1.086,000 . \\
\$ 1.131,000 .\end{array}$ & 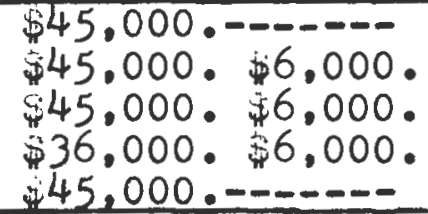 & $\begin{array}{l}-\overline{16}(+1) \\
17(+1) \\
18(+1) \\
--\end{array}$ \\
\hline$\overline{\text { III. }}$ & $\begin{array}{l}1988 \\
1989 \\
1990 \\
1991 \\
1992\end{array}$ & $\begin{array}{l}1989 \\
1990 \\
1991 \\
1992 \\
1993\end{array}$ & $\begin{array}{l}30 \\
30 \\
30 \\
30 \\
30\end{array}$ & $\begin{array}{l}39.200 \\
40.500 \\
41.500 \\
42.500 \\
43.500\end{array}$ & $\begin{array}{l}\$ 1.176,000 . \\
\$ 1.215 .000 . \\
\$ 1.245 .000 . \\
\$ 1.275 .000 . \\
\$ 1.305,000 .\end{array}$ & 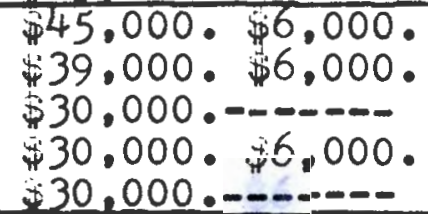 & $\begin{array}{l}19(+1) \\
20(+1) \\
-- \\
21(+1) \\
--\end{array}$ \\
\hline
\end{tabular}

The capital expenditure of $\$ 6,000$. per police car is reasonably within the confines of the proposed budgetary increases. Recreation Department

Capital expenditures for playground improvements (Davisville Playground- FY 83-84 and FY 84-85=10K; Quidnessett Playground- FY 85-86 =5K; Camp Avenue Playground- FY $86-87=$ 5K: Slocum Playground- FY 92-93 = 5K) were estimated from the following construct. It was well within projected budgetary Increases to ask for these expenditures--assuming a constant level of service per capita and no outside economical influences, 1.e.. Inflation. Calculations point out that $\$ 6.30$ is presently spent per person by the recreation department. (FY 77-78 Budget-\$148,284/23.500 (population June 30,1978) equals $\$ 6.30$ ). Th1s $\$ 6.30$ figure w111 be used as the standard. 
Perlod July 1 June 30 stand. Popula- tion Budget Increase Expenditure

Perlod July 1 June 30 stand. Popula- $\begin{gathered}\text { tion } \\ \text { Budget Increase Expenditure }\end{gathered}$

\begin{tabular}{|c|c|c|c|c|c|c|}
\hline $\begin{array}{l}\text { Present } \\
\text { I. }\end{array}$ & $\begin{array}{l}1977 \\
1978 \\
1979 \\
1980 \\
1981 \\
1982 \\
\end{array}$ & $\begin{array}{l}1978 \\
1979 \\
1980 \\
1981 \\
1982 \\
1983\end{array}$ & $\begin{array}{l}6 \cdot 30 \\
6 \cdot 30 \\
6 \cdot 30 \\
6 \cdot 30 \\
6 \cdot 30 \\
6 \cdot 30 \\
\end{array}$ & $\begin{array}{l}23.500 \\
24.700 \\
25.700 \\
26.700 \\
28.500 \\
30.500 \\
\end{array}$ & $\begin{array}{l}\$ 148,284 . \\
\$ 155.610 . \$ 7.326 \\
\$ 161.910 . \$ 6.300 \\
\$ 168,210 . \$ 6.300 \\
\$ 179.550 . \$ 11.340 \\
\$ 192,150 . \$ 12,600 .\end{array}$ & $(\$ 9.000.) \mathrm{a}$ \\
\hline$\overline{\text { II. }}$ & $\begin{array}{l}1983 \\
1984 \\
1985 \\
1986 \\
1987\end{array}$ & $\begin{array}{l}1984 \\
1985 \\
1986 \\
1987 \\
1988\end{array}$ & $\begin{array}{l}6 \cdot 30 \\
6 \cdot 30 \\
6 \cdot 30 \\
6 \cdot 30 \\
6.30\end{array}$ & $\begin{array}{l}32.000 \\
33.500 \\
35.000 \\
36.200 \\
37.700\end{array}$ & $\begin{array}{l}\$ 201,600 . \$ 9,450 . \\
\$ 211.050 . \$ 9,450 \\
\$ 220.500 . \$ 9,450 \\
\$ 228.060 . \$ 7,560 \\
\$ 237.510 . \$ 9,450\end{array}$ & $\begin{array}{l}\$ 5.000 \\
\$ 5.000 \\
\$ 5.000 \\
\$ 5.000 \\
-\end{array}$ \\
\hline III. & $\begin{array}{l}1988 \\
1989 \\
1990 \\
1991 \\
1992 \\
\end{array}$ & $\begin{array}{l}1989 \\
1990 \\
1991 \\
1992 \\
1993 \\
\end{array}$ & $\begin{array}{l}6 \cdot 30 \\
6 \cdot 30 \\
6 \cdot 30 \\
6 \cdot 30 \\
6.30 \\
\end{array}$ & $\begin{array}{l}39.200 \\
40.500 \\
41.500 \\
42.500 \\
43.500\end{array}$ & 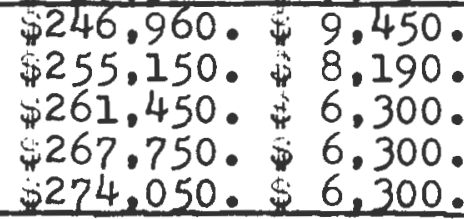 & $\$ 5,000$ \\
\hline
\end{tabular}

Note: As stated previously, (a) refers to Central and Feurer Park improvement costs taken from the Town Manager's proposed Capital Improvement Program (1978-1984), and, (b) represents the Recreation Department's request for McGinn Park Tennis courts resurfacing within the respective fiscal year. These figures are not derived from the preceding rationale. 


\section{APPENDIX D \\ LOW AND MODERATE INCOME HOUSING DATA}

Before describing how the housing limits were derived, a few general comments are in order. These "limits" are not exact, detalled figures. However, they are good "ball park" approximations. These figures can serve as workable guides for town administrators both as approximations and 1llustrations (to demonstrate how the low and moderate income housing section of the point system would operate in conjunction with the housing limits).

The flgures do not account for the expected proportional rise in elderly population, the possible re-use of navy units for low and moderate income housing, and the possible rehabilitation of any number of units over the fifteen year period. The figures do account for projected population increases and represent limits that would include any federal or state programs. In other words, the twenty-six (26) units of elderly housing needed between 1979-1983 represents a figure of total low and moderate income elderly need, not dependent on whether any federal or state program would satisfy this need in whole or in part. Definitions

Lower income groups consist of both low income and moderate income groups. Lower income would mean a family of 
Assumptions

We assumed the 1.8 elderly persons per/household and the 4 non-elderly persons per/household would remain constant over the fifteen year perlod. We also assumed that the percentages of lower income groups of the total population would remain constant over the fifteen year period, $7.5 \%$ low income, $7.5 \%$ moderate income, and $.84 \%$ lower income elderly. We also assumed that for every one household, one unit would be needed. For example, ten (10) households need ten (10) units.

To get the housing unit limit for elderly between 19791983 we :

1) multiplied the population projections of Statewlde Planning by $.84 \%$.

$\begin{array}{lllll}1979 & \underline{1980} & \underline{1981} & \underline{1982} & \underline{1983} \\ 24.0 & 25.5 & 26.0 & 27.5 & 29.5 \\ \frac{.84}{202} & \frac{.84}{214} & \frac{.84}{218} & \frac{.84}{231} & \frac{.84}{248}\end{array}$

2) We then subtracted, (1983-1979 or $248-202=46$ population increase in lower income elderly).

3) To compute the number of new units needed or the unit limit, we divided $46 / 1.8=\underline{26}$ units.

4) The 202 lower income elderly in 1979 would break down into 112 lower income elderly households, $202 / 1.8=112$ households.

5) The same was done for the 1984-1988 and 1989-1993 periods. To get the moderate and low income housing unit limits

for 1979-1983 we:

1) multiplied the population projections of Statewide Planning by $7.5 \%$.

\begin{tabular}{|c|c|c|c|}
\hline 1979 & 1980 & 1981 & 1982 \\
\hline $\begin{array}{r}24.0 \\
7.5 \\
1.800\end{array}$ & $\begin{array}{r}25.5 \\
7.5 \\
1.913\end{array}$ & $\begin{array}{r}26.0 \\
\frac{7.5}{1.950}\end{array}$ & $\begin{array}{r}27.5 \\
7.5 \\
2.063\end{array}$ \\
\hline
\end{tabular}


2) We then subtracted, (1983-1979 or 2,213-1,800 = 413 moderate and 413 low income population increase).

3) To compute the number of needed new units or the unit limit we divided $413 / 4=103$ units.

4) The 1,800 low income population and the 1,800 moderate income population in 1979 would break down into 450 moderate income and 450 low income households, $1,800 / 4=$ 450 households.

5) The same was done for the 1984-1988 and 1989-1993 perlods. 


\section{BIBLIOGRAPHY}

Benson, Blank. "Time Control, Sequential Zoning: Fiamapo" In Baylor Law Rev1ew, 25, September, 1973.

Blumenthal, Hans. "The Role of Design." in Journal of American Institute of Planners, September, 1967.

Bosselman, Fred. "Can the Town of Ramapo Pass a Law to Bind the Rights of the Whole World?" In Florida State Law Review, 1, 1973.

Brower, David J.. Miner, Dallas D., and Scott, Randall W.. editors. Management and Control of Growth. Volumes $I$ and II. The Urban Land Institute, Washington, D.C., 1975.

Chung, Hyung C. "Regulating the Timing of Residential Development--The Ramapo Study," paper submitted for presentation at Conference in 1972.

City of Indio, California, Department of Planning and Development, and Living Systems, Winters, California. City of Indio. California, Planning for Energy Conservation, prepared for U.S. Dept. of Housing and Urban Development, 1977.

Coastal Resources Center, Graduate School of Oceanography, University of R.I. The Redevelopment of Quonset/ Davisville: An Environmental Assessment, Frepared for the Rhode Island Department of Economic Development, 1977 .

Commoner, Barry. The Closing Circle, Knopf Publishers, New York, lst edition, 1971 .

Cont1, Bill, and Foffman, Steve. "suit Challenges Danish Merit System," in Boulder Daily Camera, August, 1977.

Dodge, Ellen, and Foster, Howard H. Jr. Maintaining Community Identity in a Radically Changing Environment, North Kingstown Planning Forums, Sponsored by the Rhode Island Committee for the Fumanities, June, 1975.

Donald, Elliot and Marcus, Norman. "From Euclid to Ramapo: New Directions in Land Development Controls," in Hofstra Law Review, 1, September, 1973. 
Ellickson, Robert C. "Suburban Growth Controls: An Economic and Legal Analysis," in The Yale Law Journal, 86 no. 3 , January, 1977.

Fagin, Henry. "Regulating the Timing of Urban Development," Law and Contemporary Froblems, vol. 298 (1955).

Finkler, Earl. "Non-Growth as a Planning Alternative: A Preliminary Examination of an Emerging Issue," ASPO Planning Advisory Service, Report Number 283. September, 1972 .

Foehr, Stephen. "City Council Candidates Divided on Growth Control Question," in Colorado Daily, October, 1977.

Fordham Urban Law Joumal. "Growth Restrictions - Town Ordinance Conditioning Approval of Residential Sub-division Plan on Avallability of Necessary Municipal Services Held Valld," in Fordham Urban Law Joumal, 1, September, 1973.

Freilich, Robert H., et. al. "Urban Growth Management Systems," in Planning Advisory Service Report, nos. 309 and 310. American Society of Planning officials, 1975.

Freilich, Robert H. "Development Timing, Moratoria and Controlling Growth," in Institute on Planning, Zoning, and Eminent Domain, Matthew Bender Fublishers, S.W. Legal Foundation, New York, 1974.

Gifis, Steven H. Law Dictionary, Barron's Educational Series, Inc., Woodbury, N.Y.. 1975.

Goodman, William I., editor and Freund, Eric C., associate editor. Principles and Fractice of Urban Planning, published for the Institute for Training in Municipal Administration by the International City Nianagers' Association. 1968.

Haar, Charles, Land Use Planning: A Casebook on the Use, Misuse, and Re-use of Urban Land, Little, Brown, and Company, Boston, Mass., Second Edition, 1971.

Harwood, Corbin Crews. Using Land to Save Energy, Environmental Law Institute State and Local Energy Conservation Project, Ballinger Publishing Company, Cambridge, Mass . , 1977.

Hemphill, Niarion L., and Nazziott1, Donald F. Portland, Oregon Energy Conservation Demonstration Project, Volume 6: Project Overview (Draft), prepared for Mayor Nell Goldschmidt; Office of Policy Development and Research, U.S. Department of Housing and Urban Development, Contract $\mathrm{H}-2300$, June, 1977 . 
Hoffman, Steve. "Planners Accept Fermit System." in Boulder Daily Camera. February 25, 1977.

Hoffman. Steve. "How W1II Danish Ylan Affect County?" in Boulder Daily Camera. April 20, 1977.

International C1ty Manager's Association, Committee on Growth and the Environment. "Managing Growth," in Public Management, Washington, D.C.. September, 1973.

Miandelker, Daniel R. Managing our Urban Environment, Cases. Text, and Froblems, Second Edition, The Bobbs Merrill Company. Inc... Indianapolis, Indiana. 1971.

Maxwell, James A. Financing State and Local Governments, Revised Edition, The Erookings Institution, Washington, D.C.. 1969.

Merrill, Owings, Skidmore, et. al. Portland, Oregon Energy Conservation Demonstration Project, Volume 3B, Transportation and Land Use Conservation Cholces, prepared for the Policy Analysis Section, Bureau of Planning. City of Portland, Oregon, Office of Pollcy Development and Research, U.S. Department of Housing and Urban Development, Contract $\mathrm{H}-2300$, June, 1977.

National Resources Defense Council, Inc., Moss, Elaine, editor, Land Use Controls in the United States. The Dial Press/James Wade, New York. 1977.

New York University Law Review. "A Zoning Frogram for Fhased Growth: Ramapo Township's ilme Controls on Residential Development," 47, October, 1972.

North Kingstown Planning Department. Community Development Plan. North Kingstown, R.I., September, 1972.

North Kingstown Planning Department. Housing Assistance Flan. North Kingstown, R.I.. 1977.

C'Keefe, Thomas. "Time Controls on Land Use: Frophylactic Law for Planners," in Cornell Law Review, 57, 1972.

Rabinowitz, Alan. Municipal Bond Finance and Administration. W1ley-Interscience, New York, 1969.

Rhode Island Department of Economic Development. Rhode Island Bas1c Economic Statist1cs...the Economy, Summary, and Trends, 1977-1978.

Rhode Island Statewide Planning. Fhode Island's Land Management Lesislation, 1977. 
Rhode Island Statewide Flanning. Rhode Island population Frojections by County, City and Town. Technical Faper Number 25, Apri1, 1975.

Rosall, Nolan L. "Boulder Adds a Layer to Growth Nanagement Plans," in Fracticing Planner, American Institute of Planners, June, 1977.

Ruby, Robert. "Voters Seem to Say Enough," in Boulder Daily Camera, November, 1977.

Soll Conservation Service, West Warwick, R.I. Soll Conservation Map and Soll Interpretation Table, in cooperation with Rhode Island Statewide Planning Program. 1975.

Syracuse Law Review, "Zoning," 12:342, 1961.

The Providence Sunday Journal. "Rhode Island Bullding Fermit Data, in the Business Section," November and December 1977, and April, 1978.

The Urban Design Group, Inc. North Kingstown Fousing Element, 1975.

Toffler, Alvin. Future Shock, Random House, New York, 1970.

Town Engineering Department, North Kingstown, R.I. General Plan of Water System (map). 1974.

U.S. Department of Housing and Urban Development. Draft: Capacity Bullding: Local Government Approaches to Energy Conservation, July, 1977.

U.S. Department of Housing and Urban Development. Federal Insurance Administration, Flood Fiazard Map and Flood Insurance Rate Map for the Town of North kingstown, R.I., 1976 .

W1ckersham, Kirk, Jr. "A Better Way to Regulate Development," in Practicing Planner. American Institute of Flanners, September, 1977.

Williams, Norman. The Structure of Urban Zoning and Its Dynamics in Urban Planning and Development, Buttonheim Publications Corporation, New York. 1966. 


\section{List of Cases Cited}

Albright v. Town of Manlius, 34 App. D1v. 2d. 419, 423, 312 N.Y.S. 2d. 131. 18 (4th Dept. 1970), Off'd $28 \mathrm{~N} . Y$. 2d. 108, $268 \mathrm{~N} \cdot \mathrm{E} .2 \mathrm{~d} .785,320 \mathrm{~N} \cdot \mathrm{Y} . \mathrm{S} .2 \mathrm{~d} .50$ (1971)

Berenson V. Town of New Castle, 378 N.Y.S. 2d. 672 (1975)

Camara v. Warw1ck, -R.I.-, 358 A 2d. 23

Cianciaralo V. Tarro, 92 R.I. 352, 168 A 2d. 719

C1ty of Warwick V. Campbell, 82 R.I., 300

Construction Industry Association of Sonoma County v. City of Petaluma. 375 F. Supp.. 574, 6 ERC 1453, (N.D. Cal.. 1974).U.S. District Court of Appeals, $522 \mathrm{~F} .2 \mathrm{~d}$. , 897. 8 ERC 1001 (9th Circ. 1975). Certiorari Denied. 96 s. Ct. 1148 (February 23, 1976)

F.S. Royster Guano Co. V. V1rgin1a, 253 U.S. 412, 415, (1920)

Golden V. Planning Board of the Town of Ramapo. 30 N.Y. 2d. 359. $334 \mathrm{~N} \cdot \mathrm{Y} . \mathrm{S} \cdot 2 \mathrm{~d} \cdot 138,285 \mathrm{~N} \cdot \mathrm{E} \cdot 2 \mathrm{~d} \cdot 291$ (1972)

Harte v. Zoning Board, 80 R.I. 43

Lindsley V. Natural Carbonlc Gas Co., 220 U.S. 61, (1911)

Lamothe v. Zoning Board of Cumberland, 81 R.I. 96, 101

Matter of Josephs $v$. Town Clarkstown, 24 Misc. 2d. 366, 198 N.Y.S. 2d. 695 (1960)

Nectow v. C1ty of Cambridge, 277 U.S. 183 (1928)

Oakwood at Madison, Inc. V. Townsh1p of Mad1son, $117 \mathrm{~N} . \mathrm{J}$. Super. II, 20-21, 283 A 2d. 353. 358 (L. Div. 1971)

Roblnson v. Town Counc1l of Narragansett, 60 R.I. 422,434 Southern Burlington County NAACF v. Township of Mount Laurel. New Jersey Supreme Court, 1975

Udell V. Haas, $21 \mathrm{~N} . \mathrm{Y} .2 \mathrm{~d} 463,470,235, \mathrm{~N} . \mathrm{E} .2 \mathrm{~d} .897,901$, 288 N.Y.S. 2d. 888, 894 (1968)

V1llage of Euclid v. Ambler Realty Co., 272 U.S. 365 (1926) 
List of Laws, Codes, Ordinances, and Guldelines Cited

American Law Institute (ALI)

A Model Land Development Code adopted by the ALI at Washington, D.C., May 21, 1975, L1brary of Congress Catalog Number: 76-29574, 1976 .

Boulder, Colorado Ordinance No. 4208, 1977, Growth Control Ordinance.

General Laws of the State of R.I.. Title 45, Chapter 24, Zoning, Section 3 (1956).

Living Systems, winters, California A Strategy for Energy Conservation-Proposed Energy Conservation and Solar Utilization Ordinance for the City of Davis, California, 1974 .

Ramapo, New York Zoning Amendment Conditioning Development Permits on Adequate Public Facilities - 46-13.1. 1969.

42 United States Code 4332 .

Vermont Public Service Board and the Agency of Environmental Conservation

"State of Vermont Inergy Conservation Guidelines," Monteplier, Vermont, April, 1974.

Zoning Ordinance, North Kingstown, R.I., April, 1974. 


\section{Communications}

Dr. Norman Slovik, Deputy Supervisor, Ramapo, N.Y.

R. I. Dept. of Economic Development

R. I. Dept. of Community Affairs

R. I. Housing and Mortgage Finance Corporation 